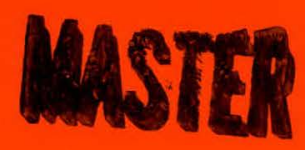

\title{
International Photovoltaic Program Plan, Volume I
}

Solar Energy Research Institute Dennis Costello Robert Koontz David Posner Patricia Heiferling

Jet Propulsion Laboratory

Paul Carpenter Sylvia Foreman Lewis Perelman
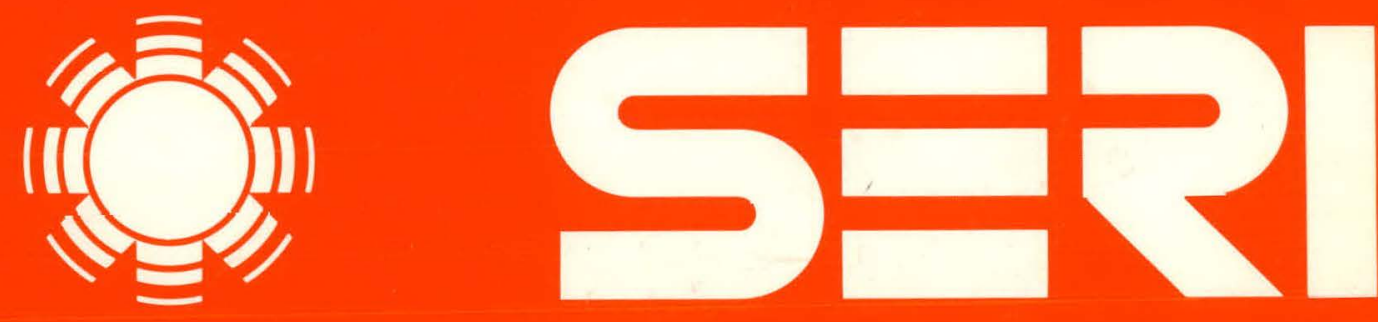

Solar Energy Research Institute A Division of Midwest Research Institute

1617 Cole Boulevard

Golden, Colorado 80401

Operated for the U.S. Department of Energy under Contract No. EG-77-C-01-4042 


\section{DISCLAIMER}

This report was prepared as an account of work sponsored by an agency of the United States Government. Neither the United States Government nor any agency Thereof, nor any of their employees, makes any warranty, express or implied, or assumes any legal liability or responsibility for the accuracy, completeness, or usefulness of any information, apparatus, product, or process disclosed, or represents that its use would not infringe privately owned rights. Reference herein to any specific commercial product, process, or service by trade name, trademark, manufacturer, or otherwise does not necessarily constitute or imply its endorsement, recommendation, or favoring by the United States Government or any agency thereof. The views and opinions of authors expressed herein do not necessarily state or reflect those of the United States Government or any agency thereof. 


\section{DISCLAIMER}

Portions of this document may be illegible in electronic image products. Images are produced from the best available original document. 


\author{
Printed in the United States of America \\ Available from: \\ National Technical Informaliui Service \\ U.S. Department of Commerce \\ 5285 Port Royal Road \\ Springfield, VA 22161 \\ Price: \\ Microfiche $\$ 3.00$ AOI \\ Printed Copy \$.25 AOn
}

\title{
NOTICE
}

This report was prepared as an account of work sponsored by the United States Government. Neither the United States nor the United States Department of Energy, nor any of their employees, nor any of their contractors, subcontractors, or their employees, makes any warranty, express or implied, or assumes any legal liability or responsibility for the accuracy, completeness or usefulness of any information, apparatus, product or process disciosed, or represents that its use would not infringe privately owned rights. 
SERI/TR-353-361

UC CATEGORY: UC-63,63A,63B,63C,63D,63E

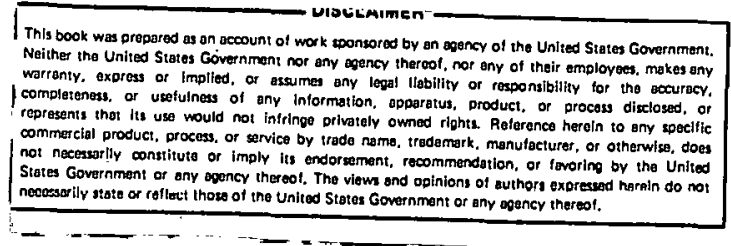

INTERNATIONAL PHOTOVOLTAIC PROGRAM PLAN, VOLUME I

\section{MASER}

DENNIS COSTELLO

ROBERT KOONTZ

DAVID POSNER

PATRICIA HEIFERLING

SOLAR. ENERgy RESEARCH INSTI TUTE

PAUL CARPENTER

SYLVIA FORMAN

LEWIS PERELMAN

JET PROPULSION LABORATORY

DECEMBER 1979

PREPAREd UNDER TASK No. 5224

Solar Energy Research Institute

1536 Cole Boulevard

Golden, Colorado 80401

A Division of Midwest Research Institute

Prepared for the

U.S. Department of Energy

Contract No. EG.77.C.01.4042 
THIS PAGE

WAS INTENTIONALLY

LEFT BLANK 


\section{FOREWORD}

The Solar Photovoltaic Energy Research, Development, and Demonstration Act of 1978 (P.L. 95-590) required the U.S. Department of Energy (DOE) to prepare an International Photovoltaic Program Plan. The Solar Energy Research Institute (SERI) and the Jet Propulsion Laboratory (JPL) were asked to do a study for DOE to be incorporated in the preparation of a report to Congress. This study is submitted to DOE in fulfillment of that request. DOE has prepared its response in compliance with P.L. 95-590. This report is presented by SERI and JPL as an independent reference document.

The Act requires cooperation and consultation among numerous government agencies. Representatives of these agencies gave freely of their time and advice. The project team would especially like to thank the following individuals: Francis Luzzatto of Action/Peace Corps; William Anderson, John Blumgart, Jerome Boskin, Norman Brown, Roger Moeller, Thomas O'Keefe, Edgar Pike, and Emmy Simmons of the Agency for International Development (AID); Nils Bassett and Larry Cozart of the U.S. Department of Commerce; William Corcoran, Norman Lutkefedder, Paul Maycock, John Mock, and Elaine Smith of DOE; Herb Haywood and Glenn Stover of the U.S. Department of Justice; Marty Prochnik of the U.S. Department of State; Ted Rosen of the U.S. Department of Treasury; John Bierman and Frank Wilson of the Export/Import Bank; Dennis Drabelle and Michael Straight of the Federal Trade Commission; Princeton Lyman and William Jones of the Institute for Scientific and Technological Cooperation; John Loria and Larry Scudder of the National Aeronautics and Space Administration (NASA); Robert Jordan of the Overseas Private Investment Corporation; and Tony Robinson of the Small Business Administration (SBA). We would also like to thank John Ashworth, Murrey Goldberg, Doug Olsen, Bob Spongberg, Peter Thompson, and George Warfield, all of SERI, for their advice and counsel.

Major subcontractor contributors to the plan include the minois Institute for Technology Research Institute (IITRI) analysis of marketing strategies (Robert Levi); the Massachusetts Institute of Technology (MIT) Energy, Laboratory's work on rural development problems (Richard Tabors and Tom Kline); Science Applications, Inc., analysis of foreign photovoltaic competition (Tom Jaras); and Strategies Unlimited's survey of photovoltaic markets and international financing (John Day and Robin Sacks). These studies were done under subcontract as part of the project.

The plan was prepared under SERI Task No. 5224. It is presented in two volumes. The first volume describes the tactics, budget, and benefits of the plan. The second volume includes subcontractor reports and other backup material necessary for a detailed understanding of the subject.

Approved for:

SOLAR ENERGY RESEARCH INSTITUTE

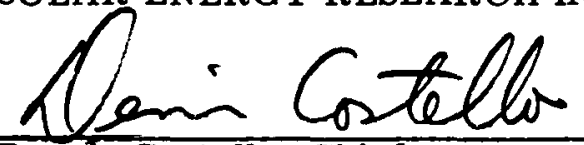

Dennis Costello, Chief

Economic Analysis Branch 
THIS PAGE

WAS INTENTIONALLY

LEFT BLANK 


\section{TABLE OF CONTENTS}

$\underline{\text { Page }}$

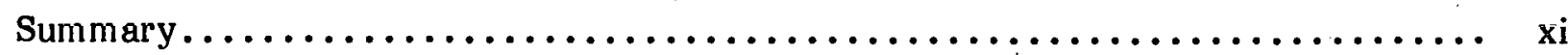

1.0 Introduction, Objectives, and Background $\ldots \ldots \ldots \ldots \ldots \ldots \ldots \ldots \ldots \ldots$

1.1 The Solar Photovoltaic Energy Research, Development, and

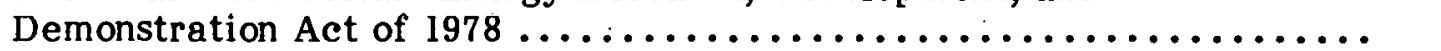

1.2 Objective and Benefits of the International Photovoltaic Program

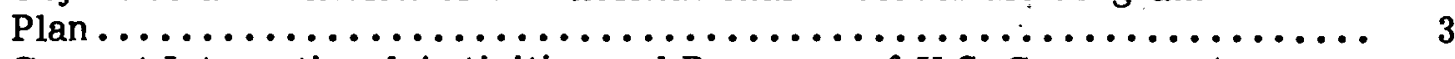

1.3 Current International Activities and Programs of U.S. Government Agencies in Photovoltaics ........................... 5

1.4 Review of the Photovoltaic Markets ..................... 13

2.0 Overview of the Plan $\ldots \ldots \ldots \ldots \ldots \ldots \ldots \ldots \ldots \ldots \ldots \ldots \ldots \ldots \ldots \ldots \ldots$

2.1 International Photovoltaic Program Plan Strategy $\ldots \ldots \ldots \ldots \ldots \ldots \ldots \ldots$

2.2 Program Elements and Tactics .......................... 19

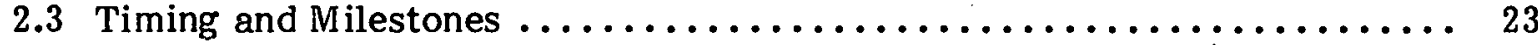

2.4 Resource Requirements ............................ 23

2.5 Relationship to Domestic Photovoltaic Programs .............. 25

3.0 Program Elements and Tactics $\ldots \ldots \ldots \ldots \ldots \ldots \ldots \ldots \ldots \ldots \ldots \ldots \ldots \ldots$

3.1 Program Element 1: Market Demonstrations................. 33

3.2 Program Element 2: Systems Development .................. 53

3.3 Program Element 3: Supplier Assistance ................... 54

3.4 Program Element 4: Purchaser Assistance and Information

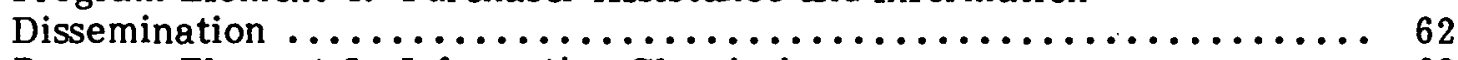

3.5 Program Element 5: Information Clearinghouse $\ldots \ldots \ldots \ldots \ldots \ldots \ldots \ldots$

4.0 Program Management.............................. 71

4.1 Management Functions of the Program Office................ 71

4.2 Agency Roles and Their Interrelations.................. 76

5.0 Proposed Budget $\ldots \ldots \ldots \ldots \ldots \ldots \ldots \ldots \ldots \ldots \ldots \ldots \ldots \ldots \ldots \ldots \ldots$

5.1 Recommended Budget for Program Element 1: Market

Demonstrations ............................... 81

5.2 Recommended Budget for Program Element 2: Systems

Development .................................. 84

5.3 Recommended Budget for Program Element 3: Supplier

Assistance .................................. 86

5.4 Recommended Budget for Program Element 4: Purchaser

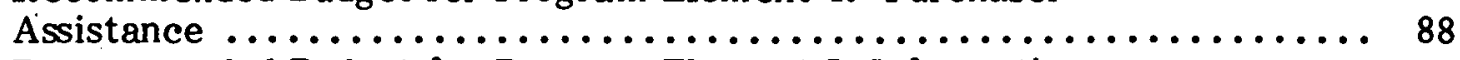

5.5 Recommended Budget for Program Element 5: Information

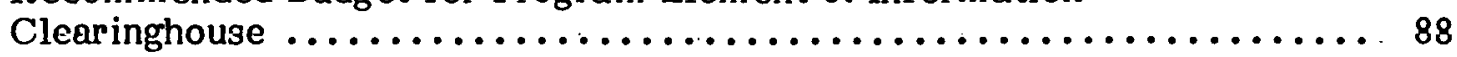

5.6 Recommended Budget for Management.................... 90

5.7 Minimum Budget Option ............................. 90 
TABLE OF CONTENTS (concluded)

Page

6.0 Expected Impacts and Benefits of the International Photovoltaics

Program Plan ..................................... 93

6.1 Estimates of the Plan's Primary and Secondary Benefits ........... 93

6.2 Impacts and Benefits Relative to the Product Development

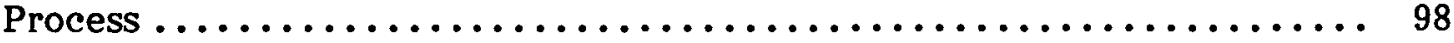

6.3 Other Benefits of the Plan........................... 102

7.0 References $\ldots \ldots \ldots \ldots \ldots \ldots \ldots \ldots \ldots \ldots \ldots \ldots \ldots \ldots \ldots \ldots \ldots \ldots \ldots$ 


\section{LIST OF PIGURES}

Page

2-1 Overview of the International Photovoltaic Program Plan ............ 20

2-2 Overview of International Photovoltaic Program Timing $\ldots \ldots \ldots \ldots \ldots \ldots \ldots$

2-3 Overview of Planned DOE Photovoltaic Program Funding Requirements and Their Relation to the Plan $\ldots \ldots \ldots \ldots \ldots \ldots \ldots \ldots \ldots \ldots \ldots \ldots \ldots \ldots \ldots$

2-4 Research, Development, and Demonstration Process for Components

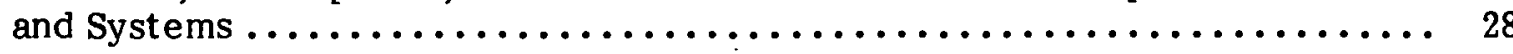

2-5 A PV Evolution Scenario $\ldots \ldots \ldots \ldots \ldots \ldots \ldots \ldots \ldots \ldots \ldots \ldots \ldots \ldots \ldots$

3-1 Commercial Market Demonstration Tactic Timing ................ 37

3-2 Development Market Demonstration Tactic Timing $\ldots \ldots \ldots \ldots \ldots \ldots \ldots \ldots$

3-3 Nongovernment Organization Demonstration Tactic Timing ........... 48

3-4 Assistance and Coordination of Bilateral and Multilateral Agreements Timing................................ 51

3-5 Supplier Assistance Program Element Timing $\ldots \ldots \ldots \ldots \ldots \ldots \ldots \ldots \ldots \ldots$

3-6 Purchaser Assistance Program Element Timing .................. 63

5-1 Market Demonstration Program Element Budget by Type of Project....... 85

6-1 Relationship Between the International Photovoltaic Plan and the Steps of the Product Development Process................... 103 


\section{THIS PAGE \\ WAS INTENTIONALLY \\ LEFT BLANK}




\section{LIST OF TABLES}

$\underline{\text { Page }}$

1 Elements and Tactics of the International Photovoltaic Program

Plan ............................................. xii

2 Proposed International Photovoltaic Program Plan Resource

Requirements.................................... xv

1-1 Current and Proposed U.S. Bilateral Agreements in Photovoltaics ......... 8

1-2 Current DOE Photovoltaic Projects Relevant to International

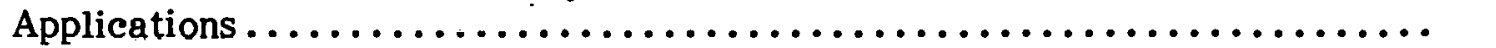

1-3 Current and Planned International Photovoltaic Projects at the

Agency for International Development ...................... 10

1-4 Ranges of Initial (1977) Breakeven Prices and Annual Market

Potentials .................................... 16

1-5 Estimated Foreign Module Sales Projections by Market Segment in

$\mathrm{MW}_{\mathrm{p}}$ (Annual).

2-1 Proposed International Photovoltaic Program Plan Resource

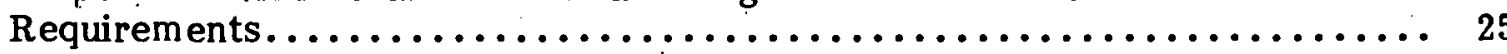

2-2 Key Milestones in the Domestic U.S. Photovoltaic R D\&D Process ........ 29

3-1 Market Demonstration Program Element Tactics and Objectives ......... 34

3-2 Examples of U.S. Nongovernment Assistance and Voluntary Organizations

Registered with the Advisory Committee on Voluntary Foreign Aid . . . . . . 49

3-3 U.S. Supplier Assistance Tactics and Objectives $\ldots \ldots \ldots \ldots \ldots \ldots \ldots \ldots \ldots \ldots$

3-4 Purchaser Assistance and Information Dissemination Tactics and

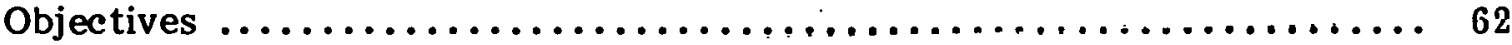

4-1 Actions and Responsibilities $\ldots \ldots \ldots \ldots \ldots \ldots \ldots \ldots \ldots \ldots \ldots \ldots \ldots$

5-1 Summary of Recommended Budget $\ldots \ldots \ldots \ldots \ldots \ldots \ldots \ldots \ldots \ldots \ldots \ldots \ldots \ldots$

5-2 Market Demonstration Program Element Recommended Budget $\ldots \ldots \ldots . \ldots 83$

5-3 Supplier Assistance Program Element Recommended Budget $\ldots \ldots \ldots \ldots \ldots$

5-4 Purchaser Assistance Program Element Recommended Budget.......... 89

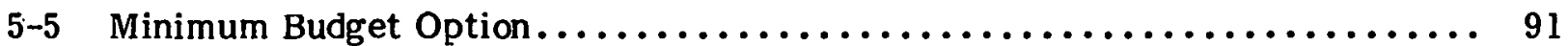

6-1 Primary Benefits of the International Photovoltaic Program Plan $\ldots \ldots \ldots \ldots$

6-2 Primary Benefits of the International Photovoltaic Program Plan $\ldots \ldots \ldots \ldots$

6-3 Secondary Benefits of the International Photovoltaic Program Plan $\ldots \ldots \ldots \ldots 99$ 
THIS PAGE

\section{WAS INTENTIONALLY LEFT BLANK}




\section{SUMMARY}

\section{OBJECTIVE AND STRATEGY}

The international photovoltaic program plan calls for the expenditure of approximately $\$ 135$ million in government funds - of which $\$ 126.5$ million would be from DOE - to accelerate the widespread use of photovoltaic systems in international markets. The program will yield two major benefits. First, it will help to maintain, stabilize, and foster the expansion of the photovoltaic industry, both in the United States and abroad, by facilitating worldwide sales. Second, it will contribute to the economic, political, and social advancement of the developing nations that utilize the technology. Other benefits will also result: reducing the rate of growth in the worldwide demand for oil; helping to improve the U.S. balance of trade; and encouraging international scientific and technological cooperation.

The strategy for achieving the plan's objective is to aggressively demonstrate photovoltaic systems in commercial and developing nation settings, and to simultaneously increase worldwide awareness of the capabilities of photovoltaics through multiple information-dissemination activities. Preparation of this plan was mandated by the U.S. Congress in the Solar Photovoltaic Energy Research, Development, and Demonstration Act of 1978 (P.L. 95-590).

\section{PROGRAM ELEMENTS AND TACTICS}

To implement the plan, a variety of specific actions are recommended. These actions are grouped into five program elements, each of which emphasizes a different aspect of the problem of accelerating the international use of photovoltaics. These elements are: market demonstrations, systems development, supplier assistance, purchaser assistance, and an information clearinghouse. All program elements will be pursued simultaneously in the plan.

The program elements were derived from legislative requirements, reviews of photovoltaic market and policy studies, examination of foreign competition in photovoltaics, and ideas generated by the photovoltaic industry. In addition, selected experts in photovoltaic market research and marketing experts with international experience suggested marketing approaches that either had worked in the past and could accelerate international awareness and acceptance of photovoltaic systcms. For clarity, each of the program elements is divided into tactics that represent more specific planned activities. The five program elements and their principal tactics are listed in Table 1. The program elements and tactics are designed to complement ongoing activities of various government agencies, primarily DOE and the U.S. Agency for International Development (AID).

\section{PROGRAM ELEMENT 1: MARKET DEMONSTRATIONS}

The first program element, market demonstrations, will show commercial buyers, various government and private assistance organizations, and international financial institutions, that photovoltaic systems are a viable and competitive alternative to their energy system needs. Market demonstrations are the centerpiece of the plan. They provide direct expcrience for polential users and U.S. suppliers. The results of demonstrations 
Table 1. ELEMENTS AND TACTICS OF THE INTERNATIONAL PHOTOVOLTAIC PROGRAM PLAN

\begin{tabular}{|c|c|c|}
\hline & Program Elements & Tactics \\
\hline & Market Demonstrations & $\begin{array}{l}\text { Commercial Market Demonstrations } \\
\text { Development Market Demonstrations } \\
\text { Nongovernment Organization Demonstrations } \\
\text { Liaison and Coordination of Bilaterial and Multi- } \\
\text { lateral Agreements }\end{array}$ \\
\hline & Systems Development & Component Development (excluding P.V. modules) \\
\hline & Supplier Assistance & $\begin{array}{l}\text { Promotional Assistance } \\
\text { Market Assessment } \\
\text { Financial and Regulatory Infor mation Outre.Ach } \\
\text { Rcview of Ferieral Regulations and Tax Slututes }\end{array}$ \\
\hline 1. & Purohasar Assistance & $\begin{array}{l}\text { Foreign Visitor Program } \\
\text { Foreign Lducatlon Plóglam } \\
\text { U.S. Embassy and AID Awareness Program }\end{array}$ \\
\hline & Infor mation Clearinghouse & $\begin{array}{l}\text { Receive and Maintain Information on Project and } \\
\text { Other Relevant Information } \\
\text { Prepare and Disseminate Information } \\
\text { Media Materials }\end{array}$ \\
\hline
\end{tabular}

will be a major source of information on system designs, performance, and costs. It is also the starting point for building the local installation and distribution contacts that will be essential if photovoltaic systems are to be used extensively in international markets.

The demonstration program element consists of four tantics: commercial market demonstrations, devélopmenl lluaiket demonetrations; nnngovernment organization demonstrations, and liaison/coordination of bilateral and multilateral agreements. Each tactic focuses on a different group of potential purchasers of photovoltaics.

The commercial market demonstration tactic is targeted toward industrialized countrics and developing countries with access to capital funds under conventional terms and from conventional lending institutions. This tactic relies primarily on the marketing ability of private industry to identify promising markets, to develop appropriate photovoltaic system designs, to form associations with local systems companies and installers in other nations, and to solicit potential purchasers willing to share the cost of demonstrations. The activities undertaken iir this tactic begin with contracts to industry to design salable systems and conduct needed market planning research. Then, a small number of englneering field tests of each design are constructed in the United States or in experimental facilities in other parts of the world. After successful engineering tests, qualified companies are awarded contracts to construct numerous (25-100) photovoltaic systems in international markets (market tests).

The second tactic, development market demonstrations, is intended to work with developing countries that are dependent on the support of assistance-giving agencies and international financial institutions for financing development projects. In this tactic, 
DOE and the photovoltaic industry could work with the U.S. Agency for International Development to identify promising photovoltaic applications, design photovoltaic systems, and conduct engineering field tests of these systems. These activities could be directed by AID because that agency is most familiar with the demands of the development market and has knowledge of the application of new technology to development programs. AID has already initiated a small photovoltaic demonstration project. This tactic would build on that existing project.

The third tactic is the demonstration of photovoltaic systems to nongovernment organizations. These organizations, through technical assistance and community development efforts, play an important role in fostering development in many regions of the world. The nongovernment-organization tactic would be a modest effort of testing and demonstrating the use of small-scale photovoltaic systems in health and agricultural applications relevant to these organizations.

The final market demonstration tactic is to take advantage of opportunities in existing and future bilateral and multilateral agreements in photovoltaics to further the objectives of the Photovoltaic Plan. Demonstration projects supported through these agreements could be an additional source of information to photovoltaics users and suppliers.

\section{PROGRAM ELEMENT 2: SYSTEMS DEVRLOPMENT}

The systems development element can be limited to a modest component development effort to optimize systems for use in specific international applications. The DOE domestic photovoltaics program is centered around major technology development for photovoltaic modules and other system components. Much of this development work can be applied to photovoltaic systems for international markets. Thus, there is little need for an extensive development program for international systems. Many photovoltaic systems for international markets can be assembled from components that have already been developed.

\section{PROGRAM ELEMENT 3: SUPPLIER ASSISTANCE}

The supplier assistance program element is designed to directly assist U.S. companies and their affiliates to market photovoltaic systems. Four tactics comprise this program element: promotional assistance activities, market assessment, financial and regulatory information outreach, and a review of federal regulations and tax statutes.

The promotional assistance tactic is aimed at helping U.S. companies to make contact with potential buyers in international markets. U.S. photovoltaic products will be promoted as a group through the support of promotional activities by trade associations and by other means.

The second tactic, supplier assistance, is to help U.S. industry identify future market opportunities. In-depth market studies on a country-specific basis are usually required before an accurate assessment of a potential market is possible. These studies are typically very costly. The U.S. Department of Commerce (DOC) may direct a series of country-specific market studies based on suitable modifications of the same techniques that DOC has applied to otheir industries. 
U.S. photovoltaic suppliers are of ten not familiar with the large number of U.S. and affiliated organizations offering financial assistance for international development programs and exports in general. Regulations and statutes governing exports and their relevance to photovoltaics are equally unknown. The third tactic is to provide information to U.S. suppliers about the financing provisions, regulations, and statutes that could assist their export activities.

U.S. sales of photovoltaics internationally, like all U.S. exports, are subject to a multitude of U.S. regulations and tax statutes. These regulations and statutes will be examined to identify opportunities for favorable interpretation or modification to lower the costs of photovoltaic exports. Assessments of international competition in photovoltaics made to support this plan found that several countries are actively promoting their photovoltaic products through flexible antitrust and tax provisions. Similar actions in the U.S. could help to counteract the current imbalance, according to some U.S. photovoltaic colripanies.

\section{PKUGRAM RLEMENT 4: PURCHASER ASSISTANCE}

Before photovoltaic systems will be used extensively in international markets, potential purchasers must become better informed about the performance and economics of these systems, and the systems' abilities to meet user needs. The purchaser assistance program. element will provide information to potential users through three information and education tactics: a foreign visitor program, a foreign education and training program, and a U.S. agency awareness program.

The foreign visitor tactic and the education and training tactic attempt to build foreign purchaser awareness, interest, and confidence in photovoltaic systems. These tactics also encourage interactions between U.S. suppliers and foreign visitors so that potential purchasers become familiar with U.S. products and how and where they can be obtained. This contact with U.S. suppliers was thought by U.S. export marketing experts to be one of the most important features of a foreign education program.

The third tactic could use existing information dissemination networks of U.S. agencies (State Department, embassies, AID missions, etc.) and nongovernment organizations. These organizations have well-developed techniques for supplying infor mation to industry and government officials in other countries and to potential purchusers, individual communities, and organizations. All of the analyses conducted in support of this plan found a need to make information on photovoltaics more available to potential purchasers.

\section{PROGRAM ELEMENT 5: INPORMATION CLEARINGHOUSE}

Information is one of the most valuable contributions the U.S. government can make to the expansion of international photovoltaic markets. Information will be readily available from the demonstrations, system development, supplier assistance, and purchaser assistance elements of the plan. The clearinghouse will serve as both a collector and disseminator of information. It will receive and maintain information on all program activities. Special information packets and mass media presentations will be prepared and disseminated to specific audiences. Existing information distribution networks in the U.S. and foreign government agencies would be used extensively in these dissemination efforts. 


\section{PLAN MANAGERENT}

To insure that program activities are managed properly, the plan calls for DOE to establish a program office to oversee implementation of the plan. The management plan uses existing agency activities and mechanisms to the fullest extent possible, but offers a central focus to coordinate, plan, and direct international photovoltaic activities. The DOE/Program Office would be responsible for coordinating various agency activities, seeing that needed assessments and evaluations are conducted, developing and applying procurement procedures, and reporting on programmatic and budgetary matters.

\section{RESOURCE REQUIREMENTS}

The recommended budget for implementing the plan totals $\$ 135$ million from FY80-88. This total includes both international photovoltaic projects planned prior to the preparation of this plan and new activities. Approximately $\$ 24.2$ million has already been proposed as required to support projects relevant to international photovoltaic activities. The remaining funds required to implement new program elements and tactics are not yet committed. Market demonstrations account for the majority (over 70\%) of the resource requirements. Market demonstrations are the primary source of information for both potential users and suppliers on photovoltaic system design, performance, cost, and marketability. Demonstration projects also require the purchase of hardware, which is more expensive than the assistance and information activities that comprise the rest of the plan. Table 2 summarizes the recommended budget by program element. Should sufficient funds not be available to support the recommended budget or should a less aggressive program be determined appropriate, a minimum budget option totalling approximately $\$ 72$ million could be adopted.

Table 2. PROPOSED INTERNATIONAL PHOTOVOLTAIC PROGRAM PLAN RRSOURCE REQUIREMENTS

(\$Millions)

\begin{tabular}{|c|c|c|c|c|c|c|c|c|c|}
\hline \multirow[b]{2}{*}{ Program Element } & \multicolumn{9}{|c|}{ Fiscal Year } \\
\hline & 80 & 81 & 82 & 83 & 84 & 85 & 86 & $87-88$ & Total \\
\hline 1. Market Demonstrations & 11.0 & 13.3 & 21.3 & 26.0 & 15.3 & 5.3 & 4.8 & 2.8 & 99.8 \\
\hline 2. Systems Development & 2.0 & 2.0 & - & - & - & - & - & - & 4.0 \\
\hline 3. Supplier Assistance & .3 & 2.15 & 2.0 & 2.0 & 1.0 & .05 & .05 & .1 & 7.65 \\
\hline 4. Purchaser Assistance & .2 & 1.25 & 2.7 & 2.4 & 2.3 & .1 & - & - & 8.95 \\
\hline 5. Information Clearinghouse & .2 & .6 & 1.0 & 1.0 & 1.0 & .6 & .5 & .1 & 5.0 \\
\hline Management & .2 & 1.2 & 2.7 & 2.6 & 1.5 & .6 & .5 & .3 & 9.6 \\
\hline Totals $^{\mathbf{a}}$ & 13.9 & 20.5 & 29.7 & 34.0 & 21.1 & 6.65 & 5.85 & $3.3 \$$ & $\$ 135.0$ \\
\hline
\end{tabular}

ancludes funds already proposed for international photovoltaic activities and funds for new activities. (See Section 5.0.) 


\section{IMPACTS AND BENEFTS}

The expenditure of a significant amount of scarce government resources to implement this plan will result in some equally significant benefits. First, the expansion of the photovoltaic industry, both in the United States and abroad, will be fostered by facilitating worldwide sales. Rapid industry expansion is particularly crucial to the United States because such expansion fills a market gap bet ween the small remote applications that are cost-effective today and the large U.S. electricity market that could be penetrated af ter major reductions in photovoltaic system prices are achieved. Without viable markets for photovoltaics at more modest prices, there is very little incentive for industry to make the investment necessary to reach these large U.S. electricity markets.

The program's benef1ts are not limited only to the United States. The program will also contribute to the economic, political, and social advancement of developing countries by providing power for development projects at reasonable costs. The program could help reduce the rate of growth in the worldwide demand for oil and other fuels, as well as eliminate the harmful environmental effects associated with some of thoco fucla.

Quantitative estimates of these benefits are difficult to obtain. However, using previous photovoltaic market analyses as a source, it is possible to make preliminary estimates of those benefits. Increased international sales of photovoltaics that could be attributed to the program range from 10-80 MW $/ \mathrm{yr}$ in 1986. The plan also acts as a lever on future sales of photovoltaics. Preliminary estimates indicate that the incremental sales impact would expand after the plan activities have ended, resulting in a 100-500 $\mathrm{MW}_{\mathrm{p}}$ annual addition to sales by the year 2000 .

Secondary benefits of the plan must also be considered. Secondary benefits are those resulting directly from the expenditure of government funds. In this program, the secondary benefits are measured by the number of systems purchased with government funds, the number of visitors informed, and the number of installers and other technicians trained. Nearly $2 \mathrm{MW}_{\mathrm{p}}$ of photovoltaic systems relevant to international markets will be installed during the program. At lesst 25 U.S. oompanicn would gain liiteriutiuntul marketing experience, and approximately 2,500 foreign nationals and technicians would receive instruction and information on photovoltaic systems technology and economics. These secondary benefits are only intermediate outcomes of the program. However, they are significant to the small but growing photovoltaic industry.

Through discussions with industry and government officials and analytical work done in preparation of the plan, a large amount of information was assembled on international markets for photovoltaics and on the role that the U.S. government should play in the development of these markets. Although it was impossible to resolve all the issues identified and still accomplish the goals of the legislation, the jlan responds to most of the issues raised. The plan also provides a focus for coordinated federal assistance to the U.S. photovoltaic industry, while simultaneously addressing the needs of developing countries. 
SECTION 1.0

\section{INTRODUCTION, OBJECTIVES, AND BACKGROUND}

This plan was prepared in response to the Solar Photovoltaic Energy Research, Development, and Demonstration Act of 1978 (P.L. 95-590). It is organized into six major sections. This first section discusses the Act, the objectives and benefits of the plan, and international activities and programs of U.S. Government agencies relevant to photovoltaics.

Sec. 2.0 presents an overview of the plan. The plan's strategy, major program elements, timing, milestones, resource requirements, and relationships to domestic photovoltaic programs are summarized here. Detailed descriptions of the plan's program elements and tactics are presented in Sec. 3.0. Sec. 4.0 contains a discussion of the management plan and Sec. 5.0 describes the recommended budget. The last section covers the benefits and impacts estimated as a result of the implementation of the plan.

A second volume accompanies the plan. It summarizes the results of numerous analyses conducted to support the preparation of the plan. The appendices in Volume II include: A - Relevant Legislation and Programs; B - Programs and Government Actions Considered in Preparing the Plan; C - Introduction to Photovoltaic Technology; D - Characterization and Assessment of Potential European and Japanese Competition in Photovoltaics (Summary); E - Industry Perspectives on International Markets for Photovoltaics; F - Policy Strategies for the International Marketing of U.S. Photovoltaics; G - Impact of International Financial Institutions on Markets for Solar Energy Systems; $\mathrm{H}$ - Photovoltaics Issues in Developing Countries. These appendices, when relevant, are refer red to throughout the plan, as are other studies used in selecting the program elements and tactics which make up the plan.

\section{1.l THE SOLAR PHOTOVOLTAIC ENERGY RESEARCH, DEVELOPMENT, AND DEMONSTRATION ACT OF 1978}

On November 4, 1978, the Solar Photovoltaic Energy Research, Development and Demonstration Act of 1978 was signed into law. The Act provides for "an accelerated program of research, development, and demonstration of solar photovoltaic energy technologies leading to early competitive commercial applicability of such technologies."

The most fundamental problem facing photovoltaic conversion is the cost.* At circa 1977 prices for photovoltaic cells of $\$ 11$ per peak watt $\left(W_{p}\right)$ of output, the cost of photovoltaic energy would be $\$ 1-2 / \mathrm{kWh}$ or about 20 times more expensive than utilitygenerated power in the United States. Advances in production techniques, changes in the

*A photovoltaic energy conversion cell converts light energy (photons) into electrical energy (a voltage). This conversion is known as the "photovoltaic effect" and involves the excitation of electrons by absorption of light, thus permitting their movement through a semiconductor material. Photovoltaic cells are only one part of a complete solar photovoltaic energy system. A system includes protective coverings for the cells; a structure to support the cell; ciruitry to control and modify electrical output; and a means of storing energy, if needed. Further background about the technology is presented in Sec. 1.4 and in Volume $\amalg$, Appendix C. 
input materials, advances in design, and larger, more automated production lines have the potential of drastically reducing the price of photovoltaic systems. 'T'he Solar Photovoltaic Energy Research, Development, and Demonstration Act of 1978 is aimed at achieving these cost reductions by supporting research and development and by aggressively stimulating widespread commercial use of the technology.

Some of the key findings of the Act are that: (1) "the early demonstration of the feasibility of using solar photovoltaic energy systems for the generation of electricity could help to relieve the demand on existing fuel and energy supplies," (2) "the early development and widespread utilization of photovoltaic energy systems could significantly expand the domestic energy resource base of the United States, thereby lessening its dependence on foreign supplies," (3) "the establishment of sizable markets for photovoltaic energy systems will justify private investment in plant and equipment necessary to rcalize the economies of scale, and will result in significant reduction in unit costs of these systems," (4) "photovoltaic energy systerns are cconomically competitive with conventional energy resources for a wide variety of applications in many foreign nations at the present time, and will find additional applications with continued cost reductions," and (5) "the early development and export of snlar photovoltaic energy systems, consistent with the established preeminence of the United States in the field of high technology products, can make a valuable contribution to the well-being of the people of other nations and of this Nation's balance of trade" (Photovoltaic RD\&D Act 1978, Findings (3), (5), (6), (12), and (13)).

These findings highlight the role of international markets in the commercial development of photovoltaic energy technology. The Act calls for actions to accelerate the development of these markets and stimulate international participation and cooperation in photovoltaics. In particular, $\$ 11(\mathrm{a})$ of the Act states:

Within one year after the date of the enactment of this Act, the Secretary, in consultation with Secretary of State, the Administrator of the Agency for International Development, the Director of ACTION, the Director of the Export/Import Bank, and other appropriate Federal officials, shall. submit to the House Committee on Scionce and Technology and the Senate Committee on Energy and Natural Resources a plan for demonstrating applications of solar photovoltaic energy systems and facilitating their widespread use in other nations, especially those with agreements for scientific cooperation with the United States. (b) The Secretary is authorized to encourage, to the maximum extent practicable, international participation and cooperation in the development and maintenance of programs established under this plan. The Secretary, in consultation and cocperation with the Federal officials specified in subsection (a), shall insure to the maximum extent possible that the plan submitted under subsection (a) and any other international activities under this section are consistent with and reflective of any similar activities or requirements under any other Federal statute, specifically including any of the several programs under other agencies and Departments involving United States international cooperation and assistance in nonnuclear energy technology, and will not duplicate activities under such programs. The plan required in subsection (a) shall specifically identify all such programs and statutes and describe how the activities under this section will be consistent with such programs, will be coordinated with them, and will avoid duplication of activities under such programs (Photovoltaic RD\&D Act 1978, \$11(a)). 
This draft plan fulfills the requirements of the Act. Appendix A identifies relevant programs and describes their interaction with the plan. Sec. 1.3.2 summarizes these programs and describes their relationship to the plan.

\subsection{OBJECTIVE AND BENEFTS OF THE INTERNATIONAL PHOTOVOLTAIC PRO- GRAM PLAN}

Commercial sales of photovoltaic systems are being made today primarily to fulfill power needs in remote locations around the world for communications and for corrosion protection of pipelines, wells, and bridges. These markets will expand significantly and new markets will develop as the price of photovoltaic systems declines. Sales of photovoltaic systems to other nations by U.S. firms currently dominate domestic sales and are expected to continue to do so until larger U.S. residential and commercial applications become feasible. In addition, many current domestic sales are made to the government rather than to private consumers and businesses.

Present government purchases of modules or systems will not be able to provide the volume necessary to sustain the domestic industry and to reduce prices through mass production efficiencies and experience, nor will domestic commercial sales support mass production facilities until cost reduction goals are attained late in the 1980 s without incentives. The Photovoltaic RD\&D Act calls for sufficient government support, principally in the form of government procurements and the technology development program, to stimulate an annual doubling in domestic photovoltaic production capacity through 1987.

The international photovoltaic plan may help to facilitate achievement of the Photovoltaic RD\&D Act's cost reduction and production development goals while maximizing the opportunities for U.S. industry to compete successfully in developing foreign markets. That is, expanding international markets may provide incentives for increased industry production capacity, and practical commercial experience may lead to additional reductions in delivered system costs.

There is no doubt that a.great need for photovoltaic energy exists in many countries, particularly emerging and developing ones. Rising costs and restrictions on the supply of petroleum and other fossil fuels has made the search for alternative, renewable energy sources increasingly criticul to the development process (Simith 1977; Rosenbloom et al. 1979). The use of photovoltaics to provide village power or for agricultural water pumping could help to ease dependence on increasingly costly and vulnerable fossil fuel supplies, could reduce the proliferation of nuclear technology, and might confer significant environmental and economic benefits on communities and nations, especially when compared to other energy sources.

It is less certain whether the potential need for photovoltaic energy will translate into an effective market demand. Some government and industry representatives believe that photovoltaic sales in developing countries will expand significantly over the next decade. However, some experts with experience in development programs are not sure that large development markets will arise. Estimates of the potential size of the international market for photovoltaic equipment vary from tens to thousands of $M W p$.

Uncertainty in the international market for photovoltaics may discourage U.S. industry from capturing the commercial opportunities that could develop in the next several years. Though a sizable international market is likely to evolve in the long run (once 
system costs have been reduced to domcstic commercial levels) U.S. industry dominance in the international market could be retarded or lost in the interim. Also, the global energy crisis warrants an aggressive effort to accelerate the development and adoption of photovoltaics internationally.

Strong U.S. government leadership in the international use of photovoltaics could benefit both the interests of developing countries and the U.S. goal of achieving a substantial domestic capacity for photovoltaic production and use. Appropriate government activities can reduce existing uncertainties in the international market, permitting potential photovoltaic purchasers and users in developing countries to make effective decisions regarding appropriate local applications. At the same time, government activities could encourage U.S. industry to be confident about making promising investments, and thus capture the expanding commercial opportunities of the international market.

This conclusion is reinforced by the $\Lambda \mathrm{ct}$, which states "it is the proper and approuriate role of the Federal Government to underluke research, development and demonstration programs in solar photovoltaic energy technologies and to supplement and assist private industry and other entities und lliereby the general public, so as to hasten the general commercial use of such technologies" (Photovoltaic RD\&D Act 1978, $\$ 2(a),(10)$ ).

Therefore, the primary objective of the international photovoltaic plan is to accelerate the widespread use of photovoltaic systems internationally.

In achieving this objective, a number of national and international benefits will result. The first benefit will be to maintain, stabilize, and foster the expansion of the photovoltaic industry in the U.S. and abroad by facilitating international commerce and making photovoltaics more cost effective. Removal or circumvention of currcnt barriers to international sales may provide a substantial stabilizing influence on the photovoltaic industry as it encounters the stresses of rapid technological change and cost reduction.

A second benefit will be a contribution to the economic, political, and social advancement of developing countries. As mentioned earlier, steep price increases for petrolcum in oil-deficient, developing countries have slowed progress toward development goals and have eroded or neutralized the gains made by the countries themselves or through assistance provided by the United States and other donors. Photovoltaic applications for these nations could have especially important development benefits.

The third benefit will be to reduce the rate of growth in the worldwide demand for oil. Just as the domestic photovoltaic program will lead eventually to fossil-fuel displacement, so too can the international use of photovoltaics benefit other nations through the displacement of grid-connected power and through the substitution of photovoltaic devices for diesel or gas-generated electric power. Other benefits associaled witli oil displacement are:

- an easing of the competition between major consumers over limited oil supplies;

- a reduction in the long-term upward pressure on oil prices;

- a reduction in the balance-of-payment deficits of many developed and developing countries;

- a lessening of the harmful environmental effects from continued or accelerated use of traditional fuel; and

- the preservation of future nonconventional energy sources, e.g. forests, rivers, and so forth. 
A fourth benefit of meeting the plan's objective will be helping to improve the U.S. balance-of-trade position. Traditionally, the United States has maintained its trade position in the world economy through the export of high technology products, production equipment, and agricultural products. Since the rapid rise in world oil prices of the 1970 s, the United States has suffered damaging trade deficits. Widespread world sales of photovoltaics would continue the U.S. tradition of high technology trade as a means of reducing the deficit.

Finally, meeting the objective of the plan will encourage international scientific and technological cooperation through the cooperative development and demonstration of photovoltaic devices. This benefit supports previous legislation in the nonnuclear technology field and recent international commitments, such as those made at the Bonn Summit, July, 1978. (See also Sec. 1.3.)

For the plan to be successful, agencies will have to coordinate their efforts, provide for management, and monitor and assess progress toward reaching the objective. The Act establishes the following quantitative objectives for the domestic photovoltaic industry.

- Double the production of photovoltaic energy systems each year during the decade starting with FY79, measured by the peak generating capacity of the systems produced, so as to reach a total annual U.S. production of solar photovoltaic energy systems of approximately 2 million $\mathrm{kW}_{\mathrm{p}}$ and a total cumulative production of such systems of approximately 4 million $\mathrm{kW}_{\mathrm{p}}$ by $\mathrm{FY} 88$;

- Reduce the average cost of installed solar photovoltaic energy systems to $\$ 1 / \mathrm{W}_{\mathrm{p}}$ by FY88; and

- Stimulate the purchase by private buyers of at least $90 \%$ of all solar photovoltaic energy systems produced in the United States during FY88 (Photovoltaic RD\&D Act $1978, \S 2(\mathrm{a}))$.

The international plan directly supports the first numerical target of the act and indirectly supports the second and third. If these legislative production goals are to be met, then rapid growth in international sales will be essential. Available market information indicates that the production goals, as currently stated in the Act, are very ambitious.

The plan's objective of accelerating the widespread use of photovoltaic systems in intcrnational markets will be measured by the number of photovoltaic systems used abroad. Achieving the objective of the plan will contribute to the national goal of $20 \%$ of domestic energy demand to be met by renewable sources by the year 2000 through its impact on production volume and prices. During the period FY85-FY88, sales of photovoltaics to U.S. markets should expand dramatically. When this expansion occurs, the key role of international markets as a bridge to U.S. grid markets will be realized.

\subsection{CURRENT INTERNATIONAL ACTIVITIES AND PROGRAMS OF U.S. GOVERN- MENT AGENCIES IN PHOTOVOLTAICS}

In recent years, various federal agencies and departments have been undertaking activities involving photovoltaic technology in international settings. First, programs have been developed by the Department of Energy (DOE) and the Agency for International Development (AID) to demonstrate photovoltaics in international settings. Second, Congress has passed a number of Acts dealing with international activities in renewable 
energy technologies. Finally, a number of bilateral and multilateral agreements addressing solar technologies have been signed. Each of these three types of activities is summarized below.

\subsubsection{Related Legislation and U.S. Initiatives}

Legislation related to the international use of photovoltaics falls into three categories. First, there is a DOE-related legislation. Second, certain other laws call for the use of photovoltaics in federal facilities. These indirectly relate to international markets because of the nature of the system designs. Third, there are a number of acts dealing with the use of renewable technologies to promote socioeconomic development and to prevent the prolif eration of nuclear weupons.

The Department of Energy Organization Act (1977) mentions activities related to forcign policy and international trade. The Act requires the Lepartment of Energy to l'ecum= mend legislative and administrative actions to more effectively manage national energy issues, including recommendations concerning forelgn polley and inlernutiunal trade. Previous solar energy legislation, such as the Solar Energy Research, Development, and Demonstration Act of 1974, also states that the export of solar energy products can help maintain U.S. preeminence in high technology products and can contribute to the U.S. balance of trade.

Two additional pieces of legislation focus on the use of photovoltaics in federal facilities but are related to applications that could be used in international settings. The first is the Federal Photovoltaic Utilization Act (part of the National Energy Conservation Policy Act 1978). The Act establishes "a photovoltaic energy commercialization program for the accelerated procurement and installation of photovoltaic systems for electric production in federal facilities" (Energy Conservation Policy Act 1978, $\$ 563$ ). \$98 million was authorized for the program. The FY80 phase of the program's implementation will address federal applications that are similar in design and energy requirements to international photovoltaic applications. The second legislative action was an amendment to the Department of Energy Act of 1978. The amendment made approximately $\$ 12$ million available for the purchase of photovoltaic systems for use on federal facilities. The amendment is frequently referred to as the Tsongas Amendment and preceded the larger federal photovoltaic utilization plan.

The first act related to development needs is the Nuclear Nonproliferution Act of 1978, which provides "for more efficient and effective control over the proliferation of nuclear explosive capability." The Act requires the United States to cooperate with other nations in identifying nonnuclear energy alternatives to meet their needs. Emphasis is placed on the reduction of developing nations' oil dependence by the utilization of solar and other renewable energy technologies (Nonproliferation Act 1978; PRC Energy Analysis Co. 1978).

The International Development and Food Assistance Act of 1977 has a similar thrust. Sec. 119 of the Act amended the Foreign Assistance Act of 1961 to furnish assistance for cooperative programs with developing nations. These programs should deal with "energy production and conservation, with particular emphasis on programs in research, development, and the use of small-scale decentralized renewable energy sources for rural areas carried out as integral parts of rural development efforts" (Food Assistance Act 1977, \$ $119(a)(1))$. The Act authorized $\$ 18$ million in FY78 for implementing these sections. The 
Act specifically required AID, with technical assistance from DOE, to undertake programs directed toward the development and implementation of renewable and unconventional energy technologies.

The objective of the international photovoltaic plan is consistent with these previous legislative mandates and initiatives; the benefits of the plan will help realize the policies expressed therein. The balance between serving the needs of developing nations and helping the U.S. photovoltaic industry achieve cost reduction and increased sales is of paramount importance to the plan. The strategies and tactics outlined in subsequent sections simultaneously address both issues and are designed to serve both purposes.

\subsubsection{Current and Planned Multilateral and Bilateral Agreements in Photovoltaics}

The United States currently has a large number of multilateral and bilateral agreements concerning solar energy. Many of these agreements address research, development, and demonstration of photovoltaic technology.* Table 1-1 summarizes the major bilateral agreements dealing specifically with photovoltaics. To date, photovoltaics have not been a major activity in any multilateral agreements. The majority of the agreements mentioning photovoltaics call for exchange of research and development information.

Several agreements and proposals include photovoltaic demonstrations. The largest is the Saudi Solar Village Project to construct a $500 \mathrm{~kW}$ village power system in a town outside of Riyadh, Saudia Arabia (Saudi Arabian-United States Joint Commission on Economic Cooperation, 1977). The project will cost approximately $\$ 20$ million.

\subsubsection{Current U.S. Government Projects Addressing International Photovoltaic Applications}

A number of U.S. government agencies are already involved in demonstrating photovoltaic systems in other nations and facilitating their widespread use. The activities undertaken have included system experiments in other nations and system field tests in the U.S. under conditions similar to those in developing nations. In addition, some resources already have been devoted to the development of nonmodule system components for use in international applications.

Table 1-2 presents the major DOE projects addressing international photovoltaic applications. DOE's program in photovoltaics focuses primarily on the domestic use of the technology. However, a number of projects are directly related to international photovoltaic applications. The Schuchuli Indian Village Project is the most obvious example. Sec. 2.5 describes the U.S. domestic solar program and assesses the importance of international photovoltaic markets to this program.

DOE and AID have been responsible for these projects. Table 1-3 presents the current and planned projects that contain a photovoltaic component within AID. Most of these

*In addition to the bilateral and multilateral agreements with solar energy activities of which the U.S. is a direct participant, other cooperative efforts relevant to photovoltaics also exist. For example, the World Bank, with support from the United Nations Development Program, has recently initiated a project to test and demonstrate small-scale photovoltaic-powered pumps for use in irrigation in developing countries. 
Table 1-1. CURRENT AND PROPOSED U.S. BLLATERAL AGREEMENTS IN PHOTOVOLTAICS

\begin{tabular}{|c|c|c|c|}
\hline Program Title & Activities & Cognizant Organizations & $\begin{array}{l}\text { Approximate } \\
\text { Total Budgets } \\
\text { (\$ Thousands) }\end{array}$ \\
\hline $\begin{array}{l}\text { Saudi Solar Village Project (Part of } \\
\text { Saudi Arabia-U.S. Joint Program } \\
\text { for Cooperation in the Fiəld o: So- } \\
\text { lar Energy) }\end{array}$ & $\begin{array}{l}500 \quad K W_{p} \text { village power system, } \\
\text { perf crmance evaluation } 3 \text { year } \\
\text { O\& } M^{\&} \text { and training support }\end{array}$ & $\begin{array}{l}\text { U.S. DOE and Saudi } \\
\text { Arabia } \\
\text { Manajed by SERI }\end{array}$ & 20,000 \\
\hline $\begin{array}{l}\text { U.S.-Spain Treaty of Friendship and } \\
\text { Cooperation }\end{array}$ & $\begin{array}{l}\text { Joint cevelopment of two-sided } \\
\text { solar cels }\end{array}$ & $\begin{array}{l}\text { U.S. DOE and Spain } \\
\text { Susported by SERI }\end{array}$ & 1,000 \\
\hline $\begin{array}{l}\text { U.S.-U.S.S.R. Agreement for Coop- } \\
\text { eration in the Field of Energy }\end{array}$ & $\begin{array}{l}\text { Exchange of photovoltaic technical } \\
\text { information (e.g. galium arsenide: } \\
\text { multiple junction silicon cells) }\end{array}$ & $\begin{array}{l}\text { U.S. DOE and U.S.S.R. } \\
\text { Supported by SERI }\end{array}$ & 30 \\
\hline $\begin{array}{l}\text { U.S.-Italy Memorandur of Unde:- } \\
\text { standing for Joint Solar Energy } \\
\text { Programs }\end{array}$ & $\begin{array}{l}\text { Proposed } 20 \mathrm{KW} \text { photovoltaic ex- } \\
\text { perinental system and } 3-5 \mathrm{KW} \mathrm{p}_{\mathrm{p}}^{\mathrm{re}} \\
\text { mote system, research information } \\
\text { exchange }\end{array}$ & $\begin{array}{l}\text { U.S. JOE and Italy } \\
\text { Supported by SERI }\end{array}$ & $\begin{array}{l}\text { Not Yet } \\
\text { Determined }\end{array}$ \\
\hline $\begin{array}{l}\text { U.S.-Mexico Bilaterall Agreement } \\
\text { on Energy }\end{array}$ & $\begin{array}{l}\text { Basie photovaltajc research and } \\
\text { village power source demonstration }\end{array}$ & $\begin{array}{l}\text { U.S. DOE and Mexico } \\
\text { Supported by SERI }\end{array}$ & $\begin{array}{l}\text { Not Yet } \\
\text { Determined }\end{array}$ \\
\hline $\begin{array}{l}\text { Proposed U.S.-Israel Cooperative } \\
\text { Projects on Solar Energy }\end{array}$ & $\begin{array}{l}\text { Proposed research and development } \\
\text { on liminescent solar concentrators }\end{array}$ & $\begin{array}{l}\text { U.S. DOE and Israel } \\
\text { Supported by SERI }\end{array}$ & 800 \\
\hline $\begin{array}{l}\text { Proposed U.S.-Japan Solar Energy } \\
\text { Agreement }\end{array}$ & $\begin{array}{l}\text { Joini research and development in } \\
\text { photsvoltaics }\end{array}$ & $\begin{array}{l}\text { U.S. DOE and Japan } \\
\text { Supported by SERI }\end{array}$ & $\begin{array}{l}\text { Not Yet } \\
\text { Determined }\end{array}$ \\
\hline
\end{tabular}




\section{Table 1-2. CURRENT DOE PHOTOVOLTAIC PROJECTS RELEVANT TO INTERNATIONAL APPLICATIONS ${ }^{a}$}

\begin{tabular}{|c|c|c|}
\hline Project Title & Description & Cognizant Organizations \\
\hline $\begin{array}{l}\text { Schuchuli Indian } \\
\text { Village Power System }\end{array}$ & $\begin{array}{l}3.5 \mathrm{~kW} \text { remote } \\
\text { general power supply } \\
\text { for village in U.S. }\end{array}$ & $\begin{array}{l}\text { Part of Systems Tests } \\
\text { and Application } \\
\text { Photovoltaic Program } \\
\text { at DOE with support } \\
\text { from NASA }\end{array}$ \\
\hline $\begin{array}{l}\text { Indian Village } \\
\text { Refrigerator } \\
\text { Experiment }\end{array}$ & $\begin{array}{l}330 W_{p} \text { to power } \\
\text { refrigerator for } \\
\text { medicines and foods in } \\
\text { Sil Nakya, Arizona }\end{array}$ & $\begin{array}{l}\text { Used by Public Health } \\
\text { Service; also part of } \\
\text { Systems Tests and Appli- } \\
\text { cation Program (above) }\end{array}$ \\
\hline $\begin{array}{l}\text { Isk Royale } \\
\text { Refrigerator } \\
\text { Experiment }\end{array}$ & $\begin{array}{l}220 \mathrm{~W}_{\mathrm{p}} \text { to power } \\
\text { refrigerator for } \\
\text { foodstuffs for trail } \\
\text { crews around Lake } \\
\text { Superior, Michigan }\end{array}$ & $\begin{array}{l}\text { Used by National Park } \\
\text { Service; also part of } \\
\text { Systems Tests and Appli- } \\
\text { cation Program (above) }\end{array}$ \\
\hline
\end{tabular}

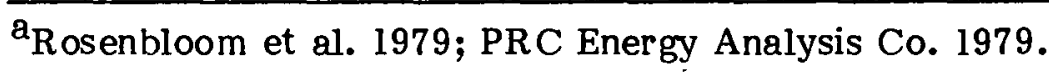


Table 1-3. CURRENT AND PLANNED INTERNATIONAL PHOTOVOLTAIC PROJECTS AT THE AGENCY FOR INTERNATIONAL DEVELOPMENT

\begin{tabular}{|c|c|c|}
\hline Project Site and Type & $\begin{array}{l}\text { Cognizant } \\
\text { Bureau/Office } \\
\text { within AID and } \\
\text { Other Agencies }\end{array}$ & $\begin{array}{c}\text { Status as of } \\
\text { July } 1979\end{array}$ \\
\hline \multicolumn{3}{|l|}{ Mali } \\
\hline $\begin{array}{l}\text { Pumping powered by photo- } \\
\text { voltaic cells. Part of larger re- } \\
\text { newable energy project. }{ }^{a}\end{array}$ & $\begin{array}{l}\text { Africa Bureau in } \\
\text { coordination with } \\
\text { DOE/SERI. Peuce } \\
\text { rnrps Vnlunteers also } \\
\text { involved. }\end{array}$ & $\begin{array}{l}\text { Approved and in early } \\
\text { implementation state. } \\
\text { Five year project }\end{array}$ \\
\hline \multicolumn{3}{|l|}{ Upper Volta } \\
\hline $\begin{array}{l}1.8 \mathrm{KW} \text { photo voltaic powered } \\
\text { pumping system for potable } \\
\text { water and grain grinding mill in } \\
\text { village. Project is part of } \\
\text { larger program on women/de- } \\
\text { velopm ent/food production, but } \\
\text { also explicitly a test and dem- } \\
\text { onstration of photovoltaic } \\
\text { system. }\end{array}$ & Africa Bureăl & $\begin{array}{l}\text { I'wo yeär project Im- } \\
\text { plemented, March, } \\
1979\end{array}$ \\
\hline \multicolumn{3}{|l|}{ Niger } \\
\hline $\begin{array}{l}\text { Demonstration of use of photo- } \\
\text { voltaics for irrigation pumping } \\
\text { as small part if } 1 \text { ill } \\
\text { institution-building project. } \\
\text { (The project involves an agree- } \\
\text { ment between United Nations } \\
\text { Educational, Scientific and Cul- } \\
\text { tural Organization (UNESCO) } \\
\text { and the Nigerian National Solar } \\
\text { Energy Laboratory for training } \\
\text { of West Africans in solar tech- } \\
\text { nology.) }\end{array}$ & $\begin{array}{l}\text { Africa Bureau with } \\
\text { Nigerian National Solar } \\
\text { Energy Laboratory }\end{array}$ & $\begin{array}{l}\text { Approved and being } \\
\text { implemented (early } \\
\text { phaso) }\end{array}$ \\
\hline \multicolumn{3}{|l|}{ Mnrnecen } \\
\hline $\begin{array}{l}\text { Larger renewable energy pro- } \\
\text { ject which allows for photo- } \\
\text { voltaic experimentation among } \\
\text { other technologies. }\end{array}$ & Near East Bureau & $\begin{array}{l}\text { Advance planning } \\
\text { state. Project } \\
\text { Proposal due by } \\
\text { August, } 1979\end{array}$ \\
\hline
\end{tabular}

\footnotetext{
a AID 1978.

$\mathrm{b}_{\text {Rosenbloom et al. } 1979 .}$
} 
Table 1-3. CURRENT AND PLANNED INTERNATIONAL PHOTOVOLTAIC PROJECTS AT THE AGENCY FOR INTERNATIONAL DEVELOPMENT (continued)

\begin{tabular}{|c|c|c|}
\hline Project Site and Type & $\begin{array}{l}\text { Cognizant } \\
\text { Bureau/Office } \\
\text { within AID and } \\
\text { Other Agencies }\end{array}$ & $\begin{array}{l}\text { Status as of } \\
\text { July } 1979\end{array}$ \\
\hline \multicolumn{3}{|l|}{ Nepal } \\
\hline $\begin{array}{l}\text { Trickle-charge battery system, } \\
\text { for use in radio communica- } \\
\text { tion. This system is part of a } \\
\text { project in teacher training. } \\
\text { Radio receivers and cassette } \\
\text { tape recorders in remote vil- } \\
\text { lages are photovoltaic powered. }\end{array}$ & Asia Bureau & $\begin{array}{l}\text { Approved and being } \\
\text { implemented. Photo- } \\
\text { voltaic component is } \\
\text { approximately } 7-9 \% \text { of } \\
\text { total funding }\end{array}$ \\
\hline \multicolumn{3}{|l|}{ Thailand } \\
\hline $\begin{array}{l}\text { No photovoltaic installations. } \\
\text { As part of a larger energy pro- } \\
\text { ject, there is an agreement to } \\
\text { keep Thailand informed of } \\
\text { 'state of art' in photovoltaics. }\end{array}$ & $\begin{array}{l}\text { Asia Bureau with } \\
\text { NASA }\end{array}$ & Approved July, 1979 \\
\hline Phillippines & 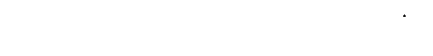 & \\
\hline $\begin{array}{l}\text { The pump irrigation component } \\
\text { of a larger nonconventional } \\
\text { energy project is photovoltaic } \\
\text { powered. }\end{array}$ & $\begin{array}{l}\text { Asia Bureau in coordi- } \\
\text { nation with DOE }\end{array}$ & $\begin{array}{l}\text { Approved and being } \\
\text { implemented. Photo- } \\
\text { voltaic component, } \\
\text { over a couple of years, } \\
\text { is approximately } 1 \% \text { of } \\
\text { total funding }\end{array}$ \\
\hline
\end{tabular}

Asia General

Asian conference on renewable energy to be held in Manilu, November, 1979, will include information on photovoltaics.

Asia Bureau

Approved

\section{Panama}

Small photovoltaic component of larger energy project.

Photovoltaic cells will be used to power radio transceivers and repeaters for remote schools.

Coordinated ApplicationsProgram with research and development and on-site emphasis on photovoltaic powered refrigeration for health clinies. Not tied to specific sites; siting to be done later, in coordination with in-country missions.

Latin America Bureau

Energy Office and Participating Agency Service Agreement (PASA) with NASA.
Approved and beginning implementation 


\section{Table 1-3. CURRENT AND PLANNED INTERNATIONAL PHOTOVOLTAIC PROJECTS AT THE AGENCY FOR INTERNATIONAL DEVELOPMENT (concluded)}

\begin{tabular}{|c|c|c|}
\hline Project Site and Type & $\begin{array}{l}\text { Cognizant } \\
\text { Bureau/Office } \\
\text { within AID and } \\
\text { Other Agencies }\end{array}$ & $\begin{array}{l}\text { Status as of } \\
\text { July } 1979\end{array}$ \\
\hline \multicolumn{3}{|l|}{ Tanzania } \\
\hline $\begin{array}{l}\text { Communication (radio) and per- } \\
\text { haps refrigeration for health } \\
\text { clinics. This is to be a small } \\
\text { demonstration projoot. }\end{array}$ & Africa Bureau & $\begin{array}{l}\text { Early planning stage by } \\
\text { Tanzania mission }\end{array}$ \\
\hline \multicolumn{3}{|l|}{ Rwanda } \\
\hline $\begin{array}{l}\text { Probable limited photovoltaic } \\
\text { component of some kind as part } \\
\text { of larger village-level re- } \\
\text { newable energy project. }\end{array}$ & Africa Bureau & Planning stage \\
\hline \multicolumn{3}{|l|}{ Tunisia } \\
\hline $\begin{array}{l}\text { Photovoltaic power for } \\
\text { village. A demonstration } \\
\text { village project in which } \\
\text { photovoltaic cells will power } \\
\text { pumping, lighting, and cottage } \\
\text { industry. }\end{array}$ & $\begin{array}{l}\text { Near East Bureau with } \\
\text { technical advice from } \\
\text { DOE and NASA }\end{array}$ & Planning stage \\
\hline \multicolumn{3}{|l|}{ Egypt } \\
\hline $\begin{array}{l}\text { Possible inclusion of photo- } \\
\text { voltaics in a larger solar/wind } \\
\text { project. }\end{array}$ & Negr F.gst Burequ & Planning stage \\
\hline \multicolumn{3}{|l|}{ Bangladesh } \\
\hline $\begin{array}{l}\text { Radio receiver system, powered } \\
\text { by photovoltaic cells, as part of } \\
\text { a larger project of flood and } \\
\text { cyclone warning for rural vil- } \\
\text { lages. Approximately } 2200 \\
\text { radio receivers will bc dictrib- } \\
\text { utcd ( } 50 \text { watts each), most of } \\
\text { which will be photovoltaic } \\
\text { powered. }\end{array}$ & $\begin{array}{l}\text { Asia Bureau in con- } \\
\text { junction with Foreign } \\
\text { Office of United States } \\
\text { Disaster Assistance }\end{array}$ & $\begin{array}{l}\text { Funds not yet } \\
\text { obligated. Slated for } \\
\text { FY80. Photovoltaic } \\
\text { component is } 20 \% \text { or } \\
\text { more of total funding }\end{array}$ \\
\hline \multicolumn{3}{|l|}{ Guyana } \\
\hline $\begin{array}{l}\text { Possible use of photovoltaics } \\
\text { with health clinic equipment. }\end{array}$ & Latin $\Lambda$ merica Burcau & Early planning stage \\
\hline
\end{tabular}


projects include the construction of either pumping or general village power photovoltaic systems.

In addition to the projects described above, which are primarily intended to test photovoltaic applications, DOE has also worked jointly with the Department of Commerce (DOC) to help U.S. industry identify problems in selling photovoltaics internationally. For example, DOE and DOC jointly-sponsored solar export management seminars have recently been organized by SERI for private industry.

There are currently two DOE draft program plans and one AID project plan in existence that describe possible future international photovoltaic activities by U.S. agencies. None of these plans has been finalized and therefore does not represent any official planning information. One of the reasons these plans are still in draft form is that the international photovoltaic program plan may result in some additions or deletions to these plans. The first plan is the Draft National Photovoltaic Program Multiyear Program Plan (DOE, June 1979). This plan outlines domestic R\&D activities in photovoltaics over the next decade. Elements of the plan are advanced research and development, technology development, systems engineering and standards, tests and applications, and the beginning commercialization activities.* The second draft plan, being developed by DOE, recognizes aspects of photovoltaics research, development, but specifically addresses com mercialization (DOE, July 1979).

The Photovoltaic Development and Support Program for AID (NASA-Lewis Research Center, March 1979) calls for a small project and is not as comprehensive as the previous ones. The project involves application of photovoltaic technology to development needs. It calls for $\$ 8.5$ million to be spent between FY79 and FY83 and is to be managed by the NASA-Lewis Research Center. At least four application demonstrations will be constructed in AID-participant nations. Other activities under the project will be development support, field support, information dissemination, and technical training.

Coordination of the two DOE plans is under way, and the final plans should specify what photovoltaics activities will be undertaken by which organizations within the Department. The AID project is separate from the DOE plans. Coordination is attained by involvement of the same personnel and organizations in implementing both the AID and DOE programs.

The international photovoltaic plan program elements and tactics that are presented in Sec. 4.0 start with these plans and attempt to build on them and integrate them into a single national focus.

\subsection{REVIEW OF THE PHOTOVOLTAIC MARKETS}

This section provides general background information on current and potential markets. Solar photovoltaic energy conversion is one of the half-dozen technologies that comprise the solar option.** Photovoltaic technology exhibits both strong attributes and difficult implementation problems.

*A draft Remote Stand-Alone Applications Implementation Plan has been prepared for DOE to support program-wide planning (NASA-Lewis, July 1979). This plan outlines system development and testing activities in remote settings.

**Others are solar thermal, solar thermal electric, wind, ocean thermal, and bioconversion. 
Again, the basic problem with photovoltaic conversion, as with most solar technologies, is cost. At today's prices, photovoltaic systems are competitive for some applicationssuch as space satellites, communications equipment, corrosion protection for bridges and pipelines, and aids to navigation that do not have ready access to the utility power grid. However, the total nongovernmental demand for solar cells today is below $1 \mathrm{MW}$ of peak capacity/yr and does not yet provide the base for the multi-MWp annual production levels that will be required to reach DOE's price goals for solar cell modules: $\$ 2.80 / W p$ by 1982 and $\$ 0.70 /$ Wp by 1986 (1980 dollars).

Reductions in photovoltaic system prices that occurred in the 1970s have opened up a number of terrestrial markets for photovoltaics. Prior to 1970, photovoltaic module sales were used almost exclusively in space systems. These space cell modules initially cost over $\$ 200 / \mathrm{Wp}$. Today, with photovoltaic module prices at approximately $\$ 10 / \mathrm{W}_{\mathrm{p}}$, the major terrestrial markets for photovoltaics are in communications and cathodic protection system3. In both of thesc markete, ealoe aro being made for systems that are operating in remote locations with small power requirements. Utility power typically is not available, or the cost of utility line extension is prohibitive. Batteries, thermal electric generators, and diesel generators are power sources for which photovoltaic systems currently are substituted. Both batteries and small-scale generators have high maintenance costs; generators typically have poor reliability characteristics and need fuel, making them expensive to use in a remote setting.

A small quantity of today's sales are made in consumer and recreation markets (battery chargers for sailboats, watches) and for remote water pumping systems located in foreign countries. Purchases by the U.S. photovoltaic program continue to account for a significant portion of total photovoltaic sales.

Annual sales of photovoltaic modules by U.S. companies have yet to exceed $1 \mathrm{MWp} / \mathrm{yr}$. In 1976, two studies estimated worldwide sales at $400 \mathrm{~kW} / \mathrm{yr}$ (BDM Corp. 1977; Intertechnology Solar Corp. 1978). The 1977 sales estimates were $750 \mathrm{~kW}$, with shipments of approximately $500 \mathrm{~kW}$ (Booz-Allen 1978, p. III-3). One study projected 1978 sales of approximately one $\mathrm{MW} / \mathrm{yr}$, with shipments of $100-800 \mathrm{~kW}$ (Booz-Allen 1978 , p.III-1). Approximately half of the 1978 sales are estimated to have been in foreign markets (DOE, April 1979, pp. 2-3).

Several studies have attempted to describe the future development of these current markets, as well as new photovoltaic markets (BDM Corp. 1977; Intertechnology Solar Corp. 1978; Aerospace Corp. 1977). Most of these studies were summarized and updated in the 1978 SERI report Photovoltaic Venture Analysis (Costello et al. 1978, pp. 23-36; D$1-D-130)$. Available market information was used in the Venture Analysis to develop ranges of descriptions that characterize potential markets for photovoltaics. These descriptions are shown in Table 1-4. Photovoltaic market research to date, while sufficient to provide a rudimentary indication of how photovoltaic markets might develop, does not allow the construction of any single-market scenario in which a high level of confidence can be placed.

In Table 1-4, break-even prices and annual potential market sizes are shown for each market sector. Break-even price and annual potential market size are important parameters in characterizing how any market will develop. A higher break-even price indicates higher costs of competitive power systems. Photovoltaics, therefore, becomes a more effective competitor in the larger market scenarios. Market potential is the upper boundary on annual potential sales and reflects the size of the market for which photovoltaics could compete. Actual sales may only be a small percentage of the potential market. 
Several observations can be made from Table 1-4. Current markets, such as U.S. and foreign communications and cathodic protection, represent only modest future markets, even under the most optimistic of the market scenarios. The potential size of these markets ranges from approximately 5-25 MW $/ \mathrm{yr}$. However, these markets can be penetrated at relatively high photovoltaic system prices, such as those typical of today's systems. Under all of the scenarios, U.S. and foreign markets are approximately equal in size for current applications.

Table 1-4 contains several potential intermediate markets. Intermediate refers to a market in which photovoltaics might be used, should substantial photovoltaic system price reductions be achieved. The $\$ 3-10 / W_{1}$ system price needed for photovoltaics to compete in intermediate markets is still well above the system prices at which photovoltaics could compete with utility-generated power in the United States (markets 13 and 14 in Table 1-4).

Four potential U.S. intermediate markets are shown: outdoor lighting, U.S. Department of Defense (DOD) applications, other U.S. government applications, and consumer applications. These markets have a total potential size ranging from $10 \mathrm{MW}_{\mathrm{p}} / \mathrm{yr}$ to nearly $400 \mathrm{MW}_{\mathrm{p}} / \mathrm{yr}$. The major components of the very large market scenario are highting and DOD applications, both of which are highly speculative markets.

Table 1-4 also shows three major foreign intermediate markets. These are low-lift and medium-lif $t$ pumping applications, and general power systems for remote villages. The total size estimates for these markets range from $16 \mathrm{MW}_{\mathrm{p}} / \mathrm{yr}$ to $305 \mathrm{MW}_{\mathrm{p}} / \mathrm{yr}$. Should the U.S. lighting market prove not to be very promising, as has been suggested by several experts, international markets have the greatest potential for photovoltaic sales in the intermediate photovoltaic system price range.

A recently completed DOE - report on the export potential for photovoltaic systems arrived at similar conclusions (DOE, April 1979). Table 1-5 presents the foreign market sales forecasts made in this study. Forecasts contained in this report indicate that foreign sales of communication and cathodic protection systems have the potential to grow more rapidly than U.S. sales in these markets during the early 1980s. The United States and foreign sales for current markets, however, are projected in the report to remain approximately equal until 1985 because of slower penetration in foreign markets. Foreign intermediate markets, such as water pumping and village power, are projected to be the dominant photovoltaic markets in the mid-1980s. As indicated in the Venture Analysis, there exists a high degree of uncertainty in these foreign intermediate markets.

Foreign water pumping and village power markets are considered the markets with the greatest future opportunity for photovoltaic sales. Pumping applications are particularly promising because of the coincidence of energy needs and solar insolation. Based on several analyses undertaken at the Massachusetts Institute of Technology Energy Laboratory and Lincoln Laboratory, it would appear that the most promising applications were those in which there was a finite return potential on the investment and one in which the farmer or other individuals in the rural area could both reap the benefit of the technology and thereby pay for it in the medium term (Smith 1977; Smith et al. 1978; Matlin 1977; Matlin et al. 1977). It is likely that the primary customers in the village power and water pumping markets will be foreign governments, international developers, and financing agencies. Much work needs to be done to understand and develop these markets before the market potential and sales forecasts cited here can be translated into significant sales. 
Table 1-4. RANGES OF INITIAL (1977) BREAKIVEN PRICES AND ANNUAL MARKET POTENTIALS ${ }^{\mathrm{a}}$

\begin{tabular}{lll}
\hline Markets & $\begin{array}{c}\text { Market Size } \\
\left(\mathrm{MW} / \mathrm{Y} \mathrm{Y}_{\mathrm{p}}\right)\end{array}$ & $\begin{array}{c}\text { System Break-even } \\
\text { Price }\left(\$ W_{\mathrm{p}}\right)\end{array}$ \\
\hline 1. U.S. Communications & $2.5-2.7$ & $20-26$ \\
2. U.S. Shallow Well Cathodic & $0.5-1.6$ & 35 \\
3. U.S. Deep Well Cathodic & $0.18-6.5$ & $11-17$ \\
4. U.S. Outdoor Lighting & $10-290$ & $1.5-4$ \\
5. U.S. Government: DOD & $0-86$ & $0-4.3$ \\
6. U.S. Government: Non-DoD & $.6-6$ & $6-8$ \\
7. U.S. Consumer & $1-3$ & $4-20$ \\
8. Forcign Communications & $1.7-10$ & $111 \%-1$. \\
9. Foreign Pumping: Low-Lift & $10-75$. & $3.5-4.25$ \\
10. Foreign Pumping: Medium-Lif t & $5-200$ & $4-9$ \\
11. Foreign Deep Well Cathodic & 0.14 .6 & $15-50$ \\
12. Foreign Remote Power & $1-40$ & $4-12$ \\
13. U.S. Grid: Sunbelt & 390 & 1.05 \\
14. U.S. Grid: Non-Sunbelt & 21.45 & 0.63 \\
\hline
\end{tabular}

${ }^{\mathrm{a}}$ Costello et al. 1978 . 
Table 1-5. ESTIMATED FOREIGN MODULE SALES PROJECTIONS BY MARKET SEGMENT IN MWp (Annual) ${ }^{a}$

\begin{tabular}{|c|c|c|c|c|c|c|c|c|c|c|c|c|c|}
\hline Market Segments & 1978 & & 1982 & & & 1986 & & & 1990 & & & 2000 & \\
\hline & & $\mathrm{L}$ & M & $\mathrm{H}$ & $\mathbf{L}$ & M & $\mathbf{H}$ & $\mathrm{L}$ & $\mathbf{M}$ & $\mathbf{H}$ & $\mathbf{L}$ & M & $\mathbf{H}$ \\
\hline Corrosion Protection & 0.008 & 1 & $\underline{1.5}$ & 1.5 & 3.2 & $\underline{4.5}$ & 4.9 & 6 & $\underline{8.5}$ & 11 & 11 & 17 & 25 \\
\hline Communications & 0.4 & 2 & $\underline{2.8}$ & 3.2 & 5.2 & $\underline{7.5}$ & 9.5 & 8 & 11 & 15 & 11 & $\underline{12}$ & 24 \\
\hline $\begin{array}{l}\text { Marking and Warning } \\
\text { Devices }\end{array}$ & 0.04 & 0.05 & $\underline{0.3}$ & 0.4 & 0.52 & 1.2 & 2.2 & 1.6 & $\underline{2.8}$ & 4.5 & 3.5 & $\underline{7.5}$ & 10 \\
\hline Water Pumping. & 0.05 & 1.2 & $\underline{5.2}$ & 5.7 & 3.7 & $\underline{29}$ & 88 & 9 & $\underline{78}$ & 250 & 70 & $\underline{470}$ & 900 \\
\hline $\begin{array}{l}\text { General Village } \\
\text { Power Sources }\end{array}$ & 0.006 & 0.3 & $\underline{0.6}$ & 1.5 & 0.9 & $\underline{10}$ & 24 & 3 & $\underline{25}$ & 100 & 10 & $\underline{100}$ & 400 \\
\hline Consumer Products & 0.009 & 0.1 & $\underline{0.1}$ & 0.1 & 0.1 & 1 & 1.3 & 2.4 & $\underline{3.5}$ & 4.4 & 8 & $\underline{9.5}$ & 14 \\
\hline Total & 0.513 & 4.65 & $\underline{10.5}$ & .12 .4 & 14 & $\underline{53}$ & 130 & 30 & $\underline{129}$ & 380 & 106 & $\underline{621}$ & 1,373 \\
\hline
\end{tabular}

QU.S. DOE, April 1979, pp. 2-6. 


\section{SEPI}




\section{SECTION 2.0}

\section{OVERVIEW OF THE PLAN}

This section presents a brief overview of the international photovoltaic plan's strategy, program elements, and tactics. It outlines major milestones and their timing and summarizes resource requirements. The plan must be viewed in the context of ongoing domestic photovoltaic programs. Therefore, the relationship between the international plan and domestic photovoltaic activities is outlined in the last part of this section.

\subsection{INTERNATIONAL PHOTOVOLTAIC PROGRAM PLAN STRATEGY}

The strategy of the international photovoltaic program plan is to accelerate the widespread use of photovoltaics in other nations by aggressively demonstrating systems in commercial and development settings and increasing awareness of the capabilities of photovoltaics using multiple and innovative techniques. In addition, it is the strategy of the plan to build on the present programs, capabilities, and expertise of U.S. government agencies. These capabilities are utilized in the plan rather than duplicated by the lead agency.

The strategy of the plan contains a number of other key elements. First, the plan balances the pursuit of development needs in other nations with efforts to foster the expansion of the U.S. photovoltaic industry. The balance is apparent in the resource requirements, timing, and priority of the individual programs in the plan. Next, the plan provides a single focus both for coordinated development assistance activities and for coordinated federal assistance to the photovoltaic industry. Finally, it is the strategy of the plan to maximize the direct contact between the suppliers of the technology and purchasers/users of photovoltaic power, in a manner consistent with U.S. foreign policy and development assistance objectives. The government's role is to facilitate and moderate this contact and to aid the diffusion of the technology. This facilitation is accomplished by selectively undertaking activities before the private sector would be willing to commit similar resources to such activities. In particular, programs will be pursued that yield benefits to all members of the industry, such as information dissemination, foreign training, trade fair attendance, and exploratory market research. Individual firms would hesitate to pursue these programs because the benefits cannot be completely captured by the firm bearing the costs (Henderson and Quandt, 1971). The plan's strategy follows the fundamental assumption of the National Photovoltaic Program (DOE, June 197.9). That is: "Commercialization is a private sector process, by definition. It is the fundamental assumption of the Program Strategy delineated here that the government can, through suitable program activities, cause the process to take place at an accelerated rate" (DOE, June 1979, pp. 1-5). At the same time, the strategy recognizes the federal government's role in U.S. foreign trade and international relations.

\subsection{PROGRAM ELEMENTS AND TACTICS}

The strategy of the plan will be implemented by the concurrent pursuit of five program elements. Each of these program elements is further divided into numerous tactics. The program elements are linked by a set of management activities. Fig. 2-1 outlines the program elements and tactics of the plan. 


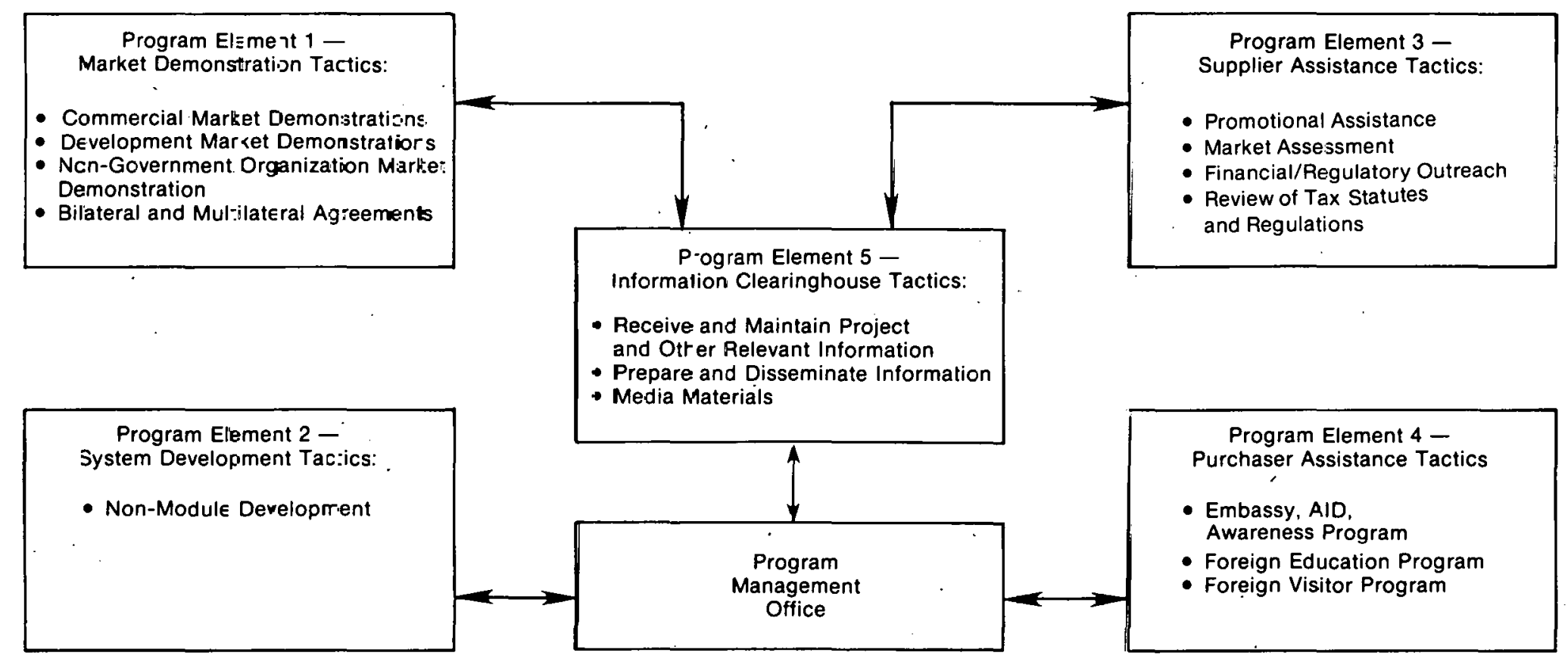

Figure 2-1. Overview of the International Photoroltaic Program Plan 
The five program elements are: (1) market demonstrations; (2) systems development; (3) supplier assistance; (4) purchaser assistance, and (5) information clearinghouse. The market demonstration element includes both engineering field tests of photovoltaic systems in the U.S. and market tests of those systems in other nations. Tactics within the demonstration program element are distinguished by the audience being addressed and the method by which the demonstrations can be implemented.

Photovoltaic systems have the potential to serve large international commercial markets. Purchasers in these markets have the internal resources or adequate access to commercial credit markets to purchase photovoltaic systems through conventional means. The U.S. photovoltaic industry is beginning to explore these opportunities but progress has been slow due to the high cost of marketing and the current high prices of photovoltaic systems. The first market demonstration tactic, commercial market demonstrations, addresses the problems in commercial markets by aggressively supporting the industry through market research and design, engineering field tests, and market tests. Market test support is also designed to provide incentives for the industry to invest in lower cost production facilities.

The second tactic is to demonstrate photovoltaic systems that serve the needs of developing countries. This tactic could be pursued primarily through AID programs, because AID has the lead U.S. responsibility and principal experience in helping to serve those needs. Through AID planned demonstration projects, other international financial assistance organizations around the world, e.g., World Bank, African Development Bank, can be made more aware of the potential usefulness of photovoltaics in serving development needs.

One highly influential group not associated with these international financial institutions are nongovernment organizations (NGO) with employees and volunteers in the developing nations of the world, e.g., Volunteers in Technical Assistance, CARE, Rockefeller Foundation, Catholic Relief Services. These organizations traditionally have been very effective in assisting developing nations. The third market demonstration tactic provides small-scale health and agricultural demonstrations targeted at the NGO audience.

The final tactic of the market demonstration program element is to make the best use of opportunities that arise through DOE participation in multilateral and bilateral agreements. As discussed above, about ten of these agreements already mention photovoltaics and future agreements in this area certainly will arise. This tactic provides a focal point for these agreements and incorporates them into a larger context of international photovoltaic activities.

The second program element of the plan is the development of key nonmodule photovoltaic system components. The single tactic in this program element has the objective of developing and improving key nonmodule photovoltaic system components unique to international applications. The design phases of the demonstration program are not long enough or large enough to address component improvements. This tactic fills that gap and contributes to reductions in the cost of the entire photovoltaic system.

The third program element addresses the competitive position of U.S. photovoltaic suppliers in international markets. It contains four tactics, two of which address market research and marketing costs while the others address financial and tax issues.

The first tactic is to provide support for U.S. attendance at international trade promotion activities. Among the first concerns raised by the current photovoltaics industry 
and by experts who export other technology-related products were the difficulties of marketing internationally. (See Appendix $E$ on photovoltaic industry viewpoints and Appendix $\mathrm{F}$ on export industry perspectives.) This tactic helps put the U.S. industry in a competitive position with other supplier nations at trade promotion activities.

Market assessment is the second tactic of the supplier assistance program element. Testimony before the Committee on Science and Technology of the U.S. House of Representatives and the Senate Committee on Energy and Natural Resources on the Photovoltaic RD\&D Act of 1978 highlighted the need for international market information on international markets (Congressional Record Vol. 124, 1978). The design and market grants that are part of the plan's demonstration program will provide some of the needed information but not in a complete or publicly available form. This tactic provides resources to conduct on-site, country-specific market studies for public use and government policy decisions (Congressional Record, March 1978). The studies will be conducted in a manner used extensively by the Department of Commerce for other U.S. export products.

Tactic three is financial and regulatory outreach. This tactic could provide both written and verbal information to the photovoltaics industry on financial and regulatory assistance programs available through U.S. agencies (such as the Small Business Administration, the Export/Import Bank, and the Department of Commerce). Outreach to the industry makes financial and regulatory programs more effective by increasing awareness. Similar activities are already under way; this project would be an extension of those activities.

The fourth tactic in the supplier assistance program element is a review of relevant tax statutes and federal regulations. This tactic was suggested by international market experts and former international sälès executives. (See Appendix F.) It máy l'epresent a low cost means of reducing the existing U.S. export barriers and could create a precedent for actions concerning export of other solar products.

The fourth program element is purchaser assistance. The three tactics that comprise this program element provide information to potential purchasers of photovoltaic systems. This element is parallel to the supplier assistance program element discussed above. Together they are designed to better inform purchasers about photovoltaics and assist suppliers in translating this awareness into sales.

The first two tactics of the purchaser assistance program element are both foreign visitor programs. The first tactic is uimed at informing international industrial and governmental decision makers in shorter, one- to two-week visits to the U.S. The second tactic is designed to provide future foreign system designers and installers with more information nbout the capabilities of photovoltaic systems through four- to six-week training sessions in the U.S. Both tactics include visits to U.S. photovoltaic experiments and manufacturers to increase direct contacts between buyers and sellers. The panel of experts on technology export emphasized the importance of such visits and direct contacts with the industry. (See Appendix F.)

The third tactic is designed to make overseas representatives of U.S. agencies (U.S. Embassies and AID Field Offices) better informed about the photovoltaic option so they can respond to inquiries from potential purchasers. The mechanisms proposed are already used to inform these organizations about other services and technologies.

The fifth program element is the information clearinghouse, which plays a vital role in meeting the plan's objective because it provides a single focal point for information. 
Information handled by the clearinghouse will include extensive data on the design, performance, and cost of the engineering field tests and the market demonstrations; information for foreign visitors; information on system development activities; and market data. The information will be used by the program manager to direct all the plan's activities and will be direct means of accelerating the use of photovoltaics.

A central program management office will be established to implement the plan. The program management of fice will report to the Assistant Secretary with responsibility for the solar program within DOE. The major responsibilities of the program manager will be: (1) policy and project analysis, monitoring, and evaluation; (2) reporting and documentation; (3) controlling and projecting the use of resources; (4) liaison with the government agencies and other relevant organizations; and (5) coordination of all the tactics in the plan.

\subsection{TIMING AND MILESTONES}

A summary of the plan's timing and key milestones are presented in Fig. 2-2. Milestones are shown for each of the plan's tactics. The figure indicates that most of the activity occurs between FY81 and FY84. The rationale for this time frame is based on the role of international markets in the evolution of photovoltaic technology. International markets can help fill the "gap" betweep current remote applications of photovoltaics and widespread use of photovoltaics in U.S. electricity markets, e.g., residences, intermediate sized load centers, and central-station utility owned generating facilities. The current price goal for photovoltaic systems in residential and intermediate load center applications is to be competitive with conventional electricity prices in 1986. Price goals for central station photovoltaic systems are aimed at reaching a competitive position by 1990 (DOE, June 1979, pp. 1-9).

Many overseas applications of photovoltaics could be cost-effective at prices only moderately lower than present ones, and at higher prices than those required for large-scale domestic markets. Therefore, the plan's activities are focused on the near-term future, before the late $1980 \mathrm{~s}$, when foreign markets are likely to continue to be the dominant opportunity for commercial development of the U.S. photovoltaic industry. Specifically, the plan's major demonstration and information dissemination activities occur mostly before 1985, after which photovoltaic system costs should be competitive in many foreign market applications. The strategy is to lay the groundwork-through technology development, demonstrations, market analysis, information, and other activities-to permit U.S. industry to compete most successfully in the growing international photovoltaic market beyond 1985 , if not sooner.

\subsection{RESOURCE REQUIREMENTS}

Table 2-1 summarizes the yearly proposed budget outlays required under the plan, by program element. The total cost of the plan is approximately $\$ 135$ million over 8 years, with most expenditures occurring between 1982 and 1985. The total budget estimate was derived from an investigation of the resources required to complete each of the tactics. Previous and ongoing photovoltaic project costs were used to estimate early engineering field tests and market field tests. The costs of these systems are expected to decline over the period and these lower costs have been used to estimate budgets in later years. Cost sharing by industry and potential users will increase the effects of funds spent on the international program. Ongoing programs are also included in the total. Details of the recommended budget are shown in Sec. 5.0 . 


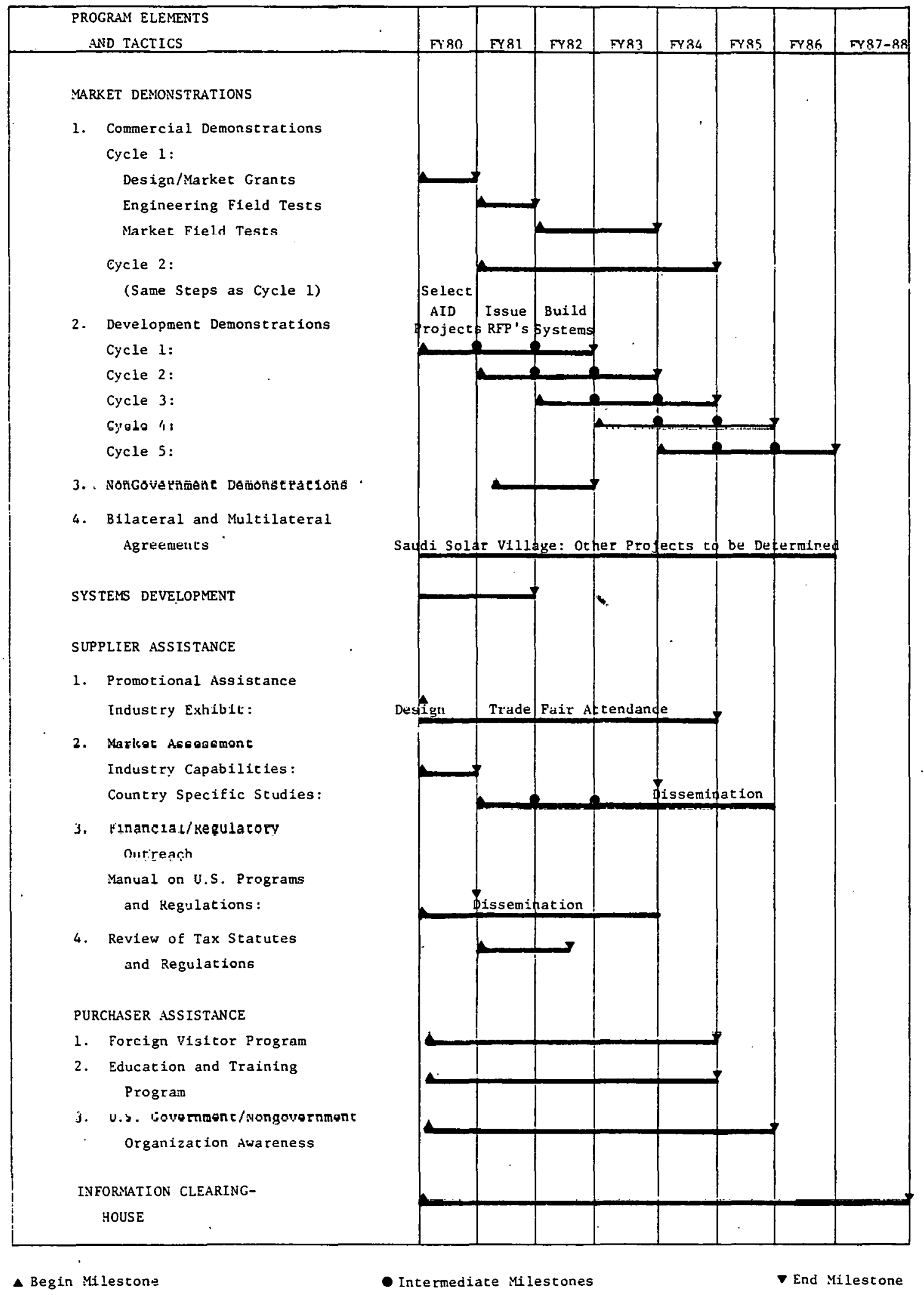

Figure 2-2. Overview of International Photovoltaic Program Timing 


\section{Table 2-1. PROPOSED INTERNATIONAL PHOTOVOLTAIC PROGRAM PLAN RESOURCE REQUIREMENTS}

(\$Millions)

\begin{tabular}{|c|c|c|c|c|c|c|c|c|c|}
\hline \multirow[b]{2}{*}{ Program Element } & \multicolumn{9}{|c|}{ Fiscal Year } \\
\hline & 80 & 81 & 82 & 83 & 84 & 85 & 868 & $87-88$ & Total \\
\hline $\begin{array}{l}\text { 1. Market Demonstrations } \\
\text { 2. Systems Development } \\
\text { 3. Supplier Assistance } \\
\text { 4. Purchaser Assistance } \\
\text { 5. Information Clearinghouse } \\
\text { Management }\end{array}$ & $\begin{array}{r}11.0 \\
2.0 \\
.3 \\
.2 \\
.2 \\
.2 \\
\end{array}$ & $\begin{array}{l}13.3 \\
2.0 \\
2.15 \\
1.25 \\
.6 \\
1.2 \\
\end{array}$ & $\begin{array}{l}21.3 \\
-- \\
2.0 \\
2.7 \\
1.0 \\
2.7 \\
\end{array}$ & $\begin{array}{l}26.0 \\
-- \\
2.0 \\
2.4 \\
1.0 \\
2.6 \\
\end{array}$ & $\begin{array}{l}15.3 \\
-- \\
1.0 \\
2.3 \\
1.0 \\
1.5 \\
\end{array}$ & $\begin{array}{l}5.3 \\
-- \\
.05 \\
.1 \\
.6 \\
.6 \\
\end{array}$ & $\begin{array}{c}4.8 \\
-- \\
.05 \\
-- \\
.5 \\
.5 \\
\end{array}$ & $\begin{array}{c}2.8 \\
-- \\
.1 \\
-- \\
.1 \\
.3 \\
\end{array}$ & $\begin{array}{l}99.8 \\
4.0 \\
7.65 \\
8.95 \\
5.0 \\
9.6 \\
\end{array}$ \\
\hline Totals ${ }^{\mathbf{a}}$ & 13.9 & 20.5 & 29.7 & 34.0 & 21.1 & 6.65 & 5.85 & 3.3 & $\$ 135.0$ \\
\hline
\end{tabular}

ancludes funds already proposed for international photovoltaic activities and fuands for new activities. (See Section 5.0.)

The Photovoltaic RD\&D Act of 1978 calls for an aggressive plan (Sec. G, 2b), but contemplates that the total federal government expenditures for photovoltaics total $\$ 1.5$ billion from 1979 to 1988 . In Fig. 2-3, the budget of the international plan is shown in the context of total expected photovoltaic outlays (DOE, June 1979, p. xiii).

\subsection{RELATIONSHIP TO DOMESTIC PHOTOVOLTAIC PROGRAMS}

To achieve significant fuel displacement in the United States,* photovoltaic systems must be capable of producing electricity "cost competitive with utility-generated electricity from conventional sources." The objective of the U.S. domestic DOE Photovoltaics Program is to reduce system costs to a competitive level in major U.S. energy markets through "extensive research, development, and demonstration, and limited product support" (DOE, June 1979). The program also will resolve the technical, institutional, legal, environmental, and social issues involved in fostering widespread adoption of photovoltaic energy systems,

Fig. 2-4 describes the DOE Photovoltaics Program in terms of the RD\&D process for components and systems. The figure defines major program milestones and the steps between initial concepts and their possible widespread commercial use. The top line shows the steps followed in the development of low-cost components for photovoltaic systems. The transition between each major program activity is identified by the milestones indicated. Each milestone is described in Table 2-2. At each step, a winnowing process occurs in which the most promising components or techniques are carried to the next step.

*The recently completed Solar Energy Domestic Policy Review estimates 1.0 quad of primary fuel for the "maximum practical case" and 0.1 quad for the " $\$ 25 / \mathrm{bbl}$ base case." 
While potential low-cost components are essential to program success, they still must be incorporated into systems that meet the requirements of specific applications. The "Applications/Systems" line begins with analysis of user requirements, leading to definition and development of several alternative systems and their requirements on components. Systems are initially those tested in a laboratory environment. Then, the most attractive candidate systems are tested in the end user's environment to establish system feasibility (Initial System Evaluation Experiments: ISEE) and, finally, system readiness. Systems successfully emerging from System Readiness Experiments (SRE) should meet user requirements and have the potential of being produced commercially at the price goal established for that application. At the commercialization stage, photovoltaic systems are cost competitive on a life-cycle cost basis and are ready, then, for widespread commercialization. Demonstration of commercial readiness then could be shown through Commercial Readiness Demonstration Projects (CRDP). Incentives to help market development and reduce costs through economies of scale in production could also be implemented during this stage.

Key elements of the U.S. domestic DOE Photovoltaic Program strategy include:

- Substantial reductions in the price of components and subsystems through:

- aggressive advanced research and development to bring advanced concepts to the point of technical feasibility; and

- intensive technology development to identify, develop, and suitably demonstrate cost-effective designs and production processes for components for which technical feasibility has been proven, thereby establishing their technology readiness.

- definition, development, design, and testing of complete photovoltaic systems in real-world applications to demonstrate, first, that such systems are feasible and, second, that they are ready for commercialization.

- development of a substantial body of experience, confidence, and expertise within the private sector on the part of both users and suppliers of photovoltaic systems.

- careful study and implementation of commercialization strategies that will encourage market penetration and stimulate emplacement of appropriate production capacity as photovoltaic technologies approach commercial readiness.

International markets potentially could fill the intermediate market gap between remote and grid-connected applications for photovoltaic systems in the United States. To help realize this potential, the International Photovoltaics Plan accounts for anticipated changes in photovoltaic technology and markets. The plan also accounts for activities already planned in the DOE domestic program.

Figure 2-5 describes a scenario for the next decade that indicates the relationship of the evolving technology to the evolving market. Program decisions are aimed at guiding and accelerating the technology through these phases with the objective of widespread commercial deployment in the United States and abroad in the late 1980s.

This scenario is characterized by four phases. The transition between each phase represents a series of events that include technological change, cost reduction, and corresponding shifts in market emphasis. In general, industry investment decisions are required during the phase transitions and government program activities are aimed at facilitating this invest ment process. 


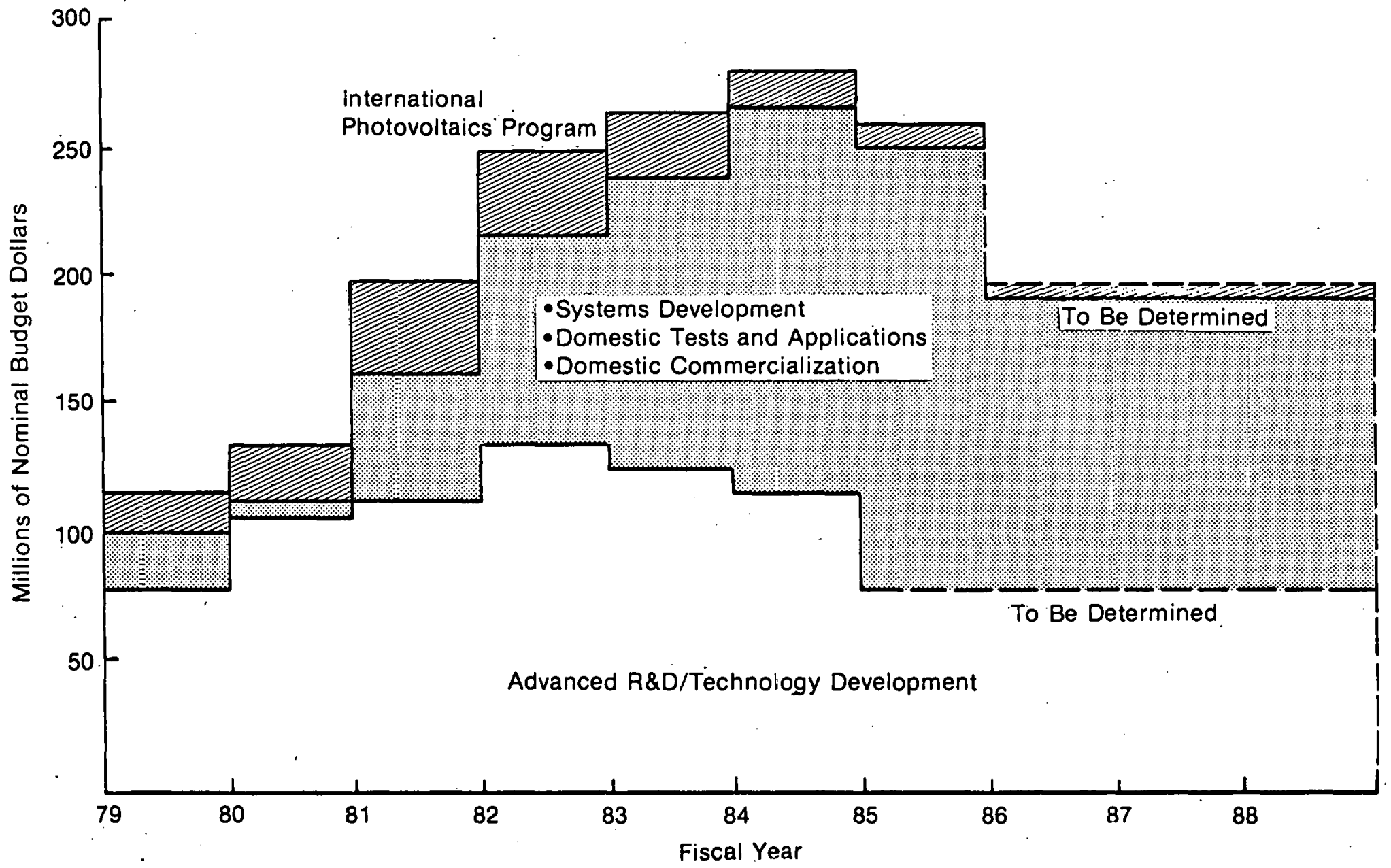

Figure 2-3. Overview of Planned DOE Photovoltaics Program Funding Requirements and Their Relation to the International Photovoltaic Program Plan ( $\$$ Million/yr) ${ }^{\text {a }}$

a Derived from DOE,June 1979 and DOE,July 1979. 


\section{COLLECTOR AND BALANCE-OF-SYSTEM COMPONENTS}

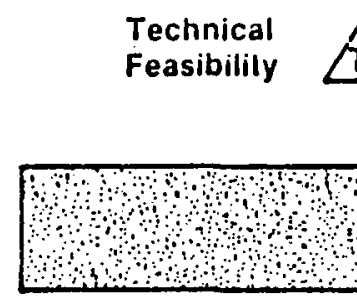

Adranced Reseaich and Development

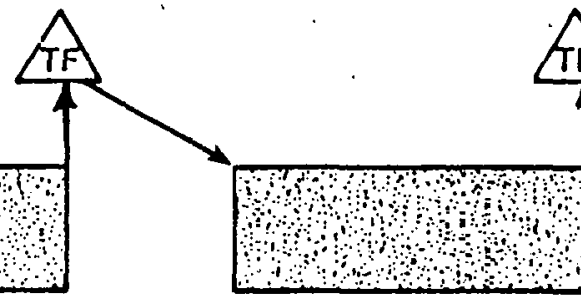

Technology Developmien

\section{Applications/Systems}

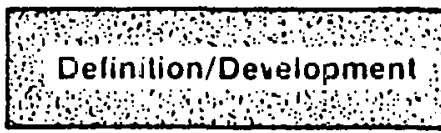

Syslem Engineering and Standards

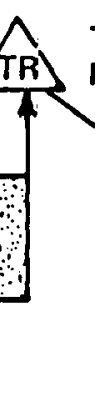

Technology

Readiness

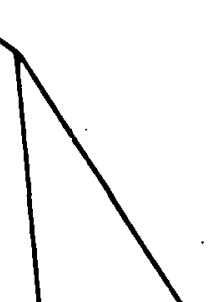

Corr merclal

Readiness
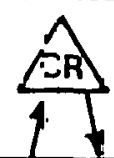

National

Energy Impacl

Figure 2-4. Research, Development, and Demonstration Process Ior Components and Systems 
Table 2-2. KEY MILESTONES IN THE DOMESTIC U.S. PHOTOVOLTAIC RD\&D PROCESS ${ }^{\mathrm{a}}$

\begin{tabular}{|c|c|}
\hline Milestones & Requirements \\
\hline Technical Feasibility (TF) & $\begin{array}{l}\text { - Stable, reproducible performance } \\
\text { characteristics } \\
\text { - Laboratory-scale process yields products } \\
\text { with consistent performance } \\
\text { characteristics } \\
\text { Mass production is feasible and likely } \\
\text { to produce an economically viable } \\
\text { product after suitable technology } \\
\text { development }\end{array}$ \\
\hline Technology Readiness (TR) & $\begin{array}{l}\text { - Appropriate subscale demonstration of } \\
\text { steps in production process } \\
\text { - Full-scale production process (i.e., in } \\
\text { sufficient quantity) expected to yield } \\
\text { product at or below price goal } \\
\text { Representative products available for } \\
\text { intensive performance and reliability } \\
\text { analysis }\end{array}$ \\
\hline System Feasibility (SF) & $\begin{array}{l}\text { System for a given application is } \\
\text { carried through detailed design, } \\
\text { installation, and successful operation } \\
\text { in user's environment } \\
\text { - Instrumented for detailed performance } \\
\text { evaluation }\end{array}$ \\
\hline System Readiness (SR) & $\begin{array}{l}\text { - System, using technology-ready } \\
\text { components or representatives thereof, } \\
\text { is designed, installed, and success- } \\
\text { fully operated } \\
\text { - User environment, design, installation, } \\
\text { and operation representative of real } \\
\text { world } \\
\text { - System capable of being profitably } \\
\text { marketed at stated price goal }\end{array}$ \\
\hline Commercial Readiness (CR) & $\begin{array}{l}\text { - System can be purchased within stated } \\
\text { price range }\end{array}$ \\
\hline
\end{tabular}

$a_{D O E}$, June 1979, pp. 1-6. 
Phase 1 describes the situation as it currently exists. The dominant technology uses single-crystal silicon cells in flat-plate modules. These cells and modules are fabricated in a highly labor-intensive batch process. In some sense this technology is already obsolete - it is unlikely that any additional capacity of this type will be added. In fact, the producer currently adding single-crystal silicon production capacity is employing an advanced, more highly automated production process. It also appears that small commercial facilities for the production of flat-plate cadmium sulfide cells and thick-film polycrystalline silicon modules will come on line within a year. Finally, many of the existing lines will evolve through the adoption of new technology toward more automation, cheaper process steps, and thus, lower cost modules. In other words, in terms of module production, we are already seeing the transition to Phase 2. The systems employing the modules in Phase 1 , however, are still largely "custom built" for specific applications, which are primarily small and remote from power grids (microwave repeaters, navigational aids, cathodic protection, etc.). The current annual market is on the order of $1-2 \mathrm{MW}_{\mathrm{p}} / \mathrm{yr}$ and is largely sold for international use at $\$ 10-25 / \mathrm{Wp}$ (1980 dollars).

The transitions between Phases 1 and 2, and Phases 2 and 3, are the most critical in terms of program success. Phase 2 will be characterized, in 1982-1984, by automated single-crystal silicon ingot technology. Furthermore, in this period new technology, such as the continuous melt-replenishment silicon ingot machine, will be available for incorporation into existing lines. Plans also call for the initial construction of pilot facilities for silicon noningot technology such as the ribbon and web processes. It is also expected that concentrator array production will occur at larger scales during this period. The market will still be dominated by foreign applications (probably for village power and water pumping) at prices in the $\$ 6-13 / W_{p}$ range. This is because, at these prices, applications in the United States will still be economically unjustified with the exception of potential military and federal remote applications markets. Total world sales will be on the order of 10-100 $\mathrm{MW}_{\mathrm{p}}$ per yeur.

In the transition to Phase 3 , the program will see the results of technology development and commercialization efforts reflected in major expansion of production capacity using both advanced ingot, noningot and concentrator technologies for the grid-connected U.S. market. Prices will fall to the $\$ 1.60-2.60 / W_{1}$ range and, if substantial progress is made in the advanced research laboratories, pilot facilities for these advanced collectors will be initiated.

It is expected that the single-family, all-electric, new construction residential market will grow fastest, to be followed by additional residential, commercial, selected industrial, and possibly, central station applications. Many different system designs, configurations, and technologies will compete for the various market segments.

Phase 4 arrives with the stable conditions expected at the beginning of the 1990s, when government commercialization efforts should no longer be needed. The industry will be competitive, composed of a healthy mix of technologies at nearly a gigawatt or greater annual output. These conditions should allow photovoltaics to achieve very high levels of photovoltaic deployment by the year 2000 .

In summary, the domestic photovoltaic plan and the international plan are both key elements to the evolution and widespread adoption of the technology. Neither plan can reach its objective unless the activities of the other are successful. 
Figure 2-5. A PV Evolution Scenario 


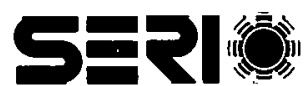




\section{SECTION 3.0}

\section{PROGRAM ELEMENTS AND TACTICS}

This section presents detailed descriptions of the program elements and tactics that compose the international photovoltaic program. To recapitulate the five program elements: (1) market demonstrations; (2) systems development; (3) supplier assistance; (4) purchaser assistance; and (5) information clearinghouse. Together with the management activities described in Sec. 4.0, they represent an integrated program for facilitating the development of international markets for photovoltaics and for advancing the role that U.S. industry will play in that development.

The descriptions of each program element begin with an overview of the objectives and tactics within the program element. A general explanation of these included objectives and tactics follows. Each tactic is then examined in detail with an overview of the approach and an explanation of how and why the approach will work.

Although each of the program elements is described separately, it should be emphasized that they will be closely coordinated during their implementation. The program management office (Sec. 4.0) will be responsible for this coordination.

\subsection{PROGRAM ELEMENT 1: MARKET DEMONSTRATIONS}

This program element is the centerpiece of the international photovoltaic program plan. It provides direct experience for potential users and U.S. suppliers to prove the capabilities of photovoltaic systems in specific international markets and applications. The results of engineering and market tests undertaken in this program element are major sources of information for improving system designs and evaluating photovoltaic system performance and economics. All information resulting from engineering and market tests and other activities in the market demonstration program element will be made publicly available through this information clearinghouse. The demonstration program element also is the starting point for building the local installation and distribution contacts that will be essential if photovoltaic systems are to be used extensively in international markets and if U.S. suppliers are to maintain a large share of world photovoltaic sales. Experience with the market demonstration tactics in this program element is likely to establish the viability of photovoltaics for use by poorer developing countries in new applications such as water pumping for both drinking and agricultural use, refrigeration, health care equipment, and remote general power. These market demonstrations will also help establish the extent to which new markets for photovoltaics exist in industrialized countries with large, rural, unelectrified areas, especially in developing countries with considerable financial resources at their disposal. Experience with photovoltaic systems installed as part of this program element could lead to significant reductions in system costs through design improvements and better manufacturing, distribution, installation, and maintenance techniques.

\subsection{Overview of the Market Demonstration Program Element Objectives and Tactics}

Table 3-1 lists the four market demonstration tactics and their respective objectives. Each tactic is designed to address a different sector of the international market. The commercial market demonstration tactic is targeted toward industrialized countries and developing countries with access to private financing. This program relies primarily on 
Table 3-1. MARKET DEMONSTRATION PROGRAM ELEMENT TACTCS AND OBJECTIVES

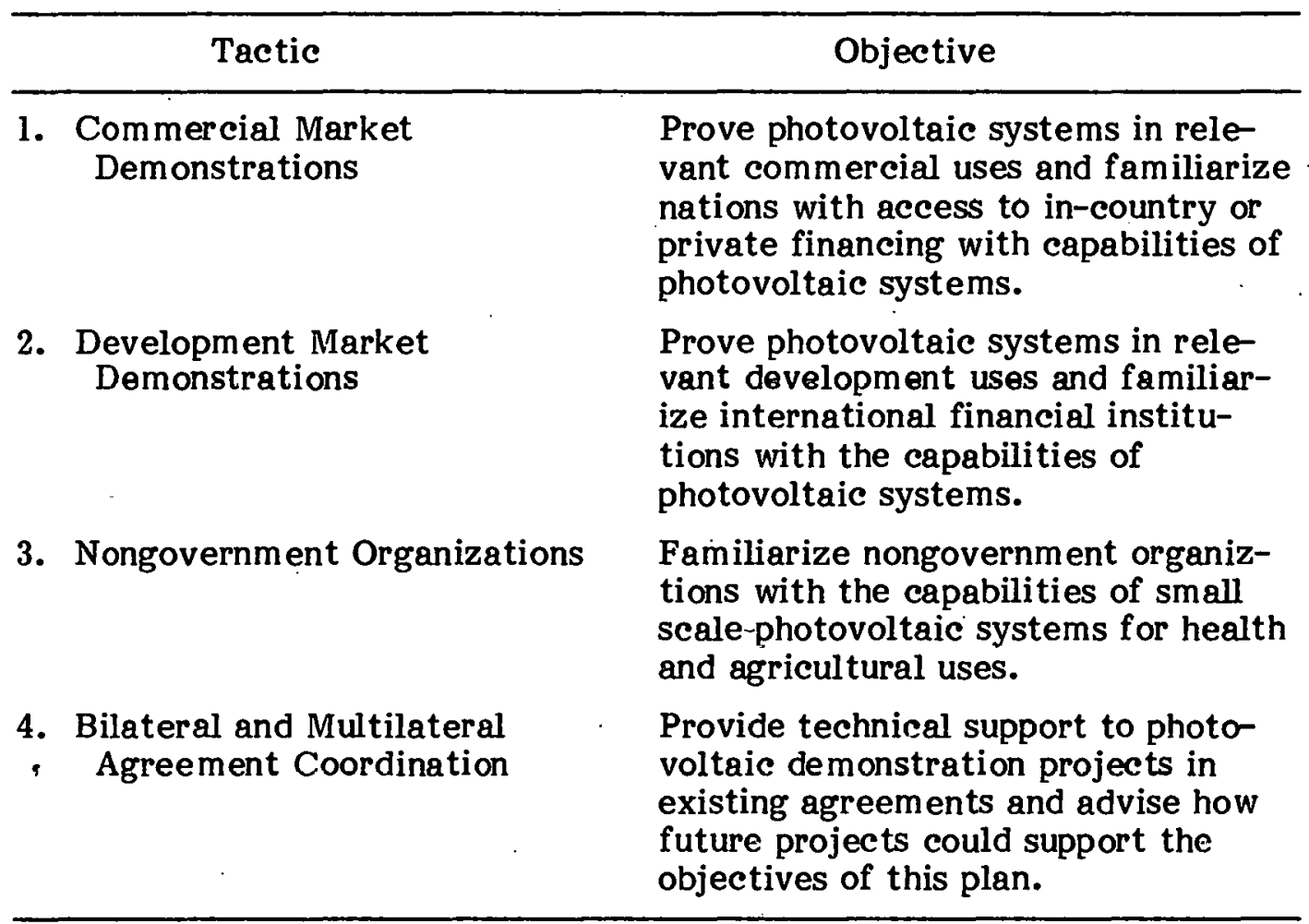


the marketing ability of private industry to identify promising markets, to develop appropriate photovoltaic applications and system designs, to form associations with incountry system companies and installers, and to solicit potential purchasers willing to cost-share photovoltaic market tests. Companies are given initial design and marketing planning grants to define markets and develop system designs. Then, multiple engineering field tests of each design are constructed in the United States or in experimental facilities in other parts of the world. After successful engineering tests, qualified companies are awarded two-year contracts to construct numerous (approximately 25 per company) photovoltaic systems in international markets with user cost sharing. An important element of the commercial program is that it provides participating companies with sufficient experience to simplify system designs and reduce photovoltaic system costs. The program also stimulates participation by many diverse companies.

The development market demonstration tactic (Tactic 2) is intended to work with poorer developing countries which are dependent on the assistance-giving agencies and international financial institutions for support of development projects. In this tactic, DOE and the photovoltaic industry could work with the U.S. Agency for International Development (AID) to identify promising photovoltaic applications, design photovoltaic systems, and conduct engineering and market tests of these systems. This program could be directed by AID because of its familiarity with the demands of the development market and experience with applying new technology in development programs.

The third tactic involves demonstration of small-scale photovoltaic systems to nongovernment organizations. These organizations, through technical assistance, community development efforts, and charity programs, play an important role in fostering development in many regions of the world. This tactic is intended to be a modest effort, emphasizing testing and demonstrating photovoltaic systems in applications relevant to the organizations.

The final tactic is to cooperate with and support demonstration projects in existing and future bilateral and multilateral agreements. These projects can provide an important additional source of information on international photovoltaic markets and systems.

To obtain the greatest possible benefits of the information and experience derived from the market demonstration program element, demonstration projects will be closely coordinated with information dissemination and promotional activities (such as industry trade fairs) of other program elements and tactics.

\subsubsection{Program Element Rationale}

Photovoltaics is an energy technology which is new and unfamiliar to most of the world. Terrestrial uses of photovoltaics to date have been limited, specialized, and typically not available for public view. This situation is particularly true for international markets which appear to have significant growth potential. To make photovoltaic systems adaptable to common and appropriate uses in other nations, these systems must be demonstrated under real environmental and social conditions. Their value to potential international purchasers and users must be demonstrated, and potential user awareness must be heightened.

Demonstrations generate crucial information for social impact assessment, technology assessment, and design improvement. The types of demonstrations discussed here are intended to be consistent with the evolutionary approach to photovoltaic applications projects now being followed in the DOE domestic photovoltaic program. 
The photovoltaic system demonstrations outlined will include opportunities for interested potential purchasers to receive technical and economic information and to examine installations first-hand in the field sites. The demonstrations will provide the evidence necessary to show potential purchasers how photovoltaic systems can effectively meet user needs in diverse development settings.

Marketing and sociological studies have established that purchasers or users of new technologies systematically progress through several stages: (1) awareness; (2) interest; (3) trial; (4) evaluation; and (5) adoption. Demonstrations address the first four stages (especially stages three and four) of this acceptance process by drawing attention to and permitting a form of testing and assessment of the innovative technology and its applications. Without the knowledge and experience represented by the first four stages of this diffusion process, potential purchasers will not adopt photovoltaic systems. Therefore, demonstrations supplemented by information dissemination are fundamental to successful commer cial impact.

Engineering and market tests offer industry an opportunity to evaluate and improve a wide range of photovoltaic designs and applications, and to gain experience with the application needs of other countries. On-site work also permits industry to begin to develop international marketing networks and a sales infrastructure. Further, sales of photovoltaic equipment for demonstrations enhance the production potential of the U.S. photovoltaic industry.

Different types of demonstration conditions each have special features and appeal to distinct potential markets. Given different short-term market possibilities, demonstrations are needed that are structured for and aimed primarily at definable classes of potential purchasers. An important feature of the market demonstration program element is that the tactics attempt to address specific sectors of the international market.

\subsubsection{Program Element 1, Tactic 1: Commercial Market Demonstrations}

\subsubsection{Tactical Objective and Summary of Approach}

The objective of the tactic is to test photovoltaic systems in relevant commercial uses and familiarize nations with access to in-country or private financing of the capabilities of photovoltaic systems. Figure 3-1 describes the timing of the commercial market demonstration tactic.

The approach can be summarized in five steps:

1. DOE works directly with photovoltaic companies to define applications, system designs and specific markets. The program consists of two cycles of projects, each of which has three phases. Cycle one begins in FY80, with projects completed in FY83. Cycle two begins in FY81 and is completed in FY84.

2. Phase 1 of each cycle is the design and market planning grants. This phase begins with DOE issuing solicitations in FY80 to industry for market planning research on promising international markets for photovoltaics. The industry selects applications and markets and does field work needed to design appropriate photovoltaic systems for those applications and to develop marketing plans. Companies are required to cost-share some part of the marketing plan preparation and product development 


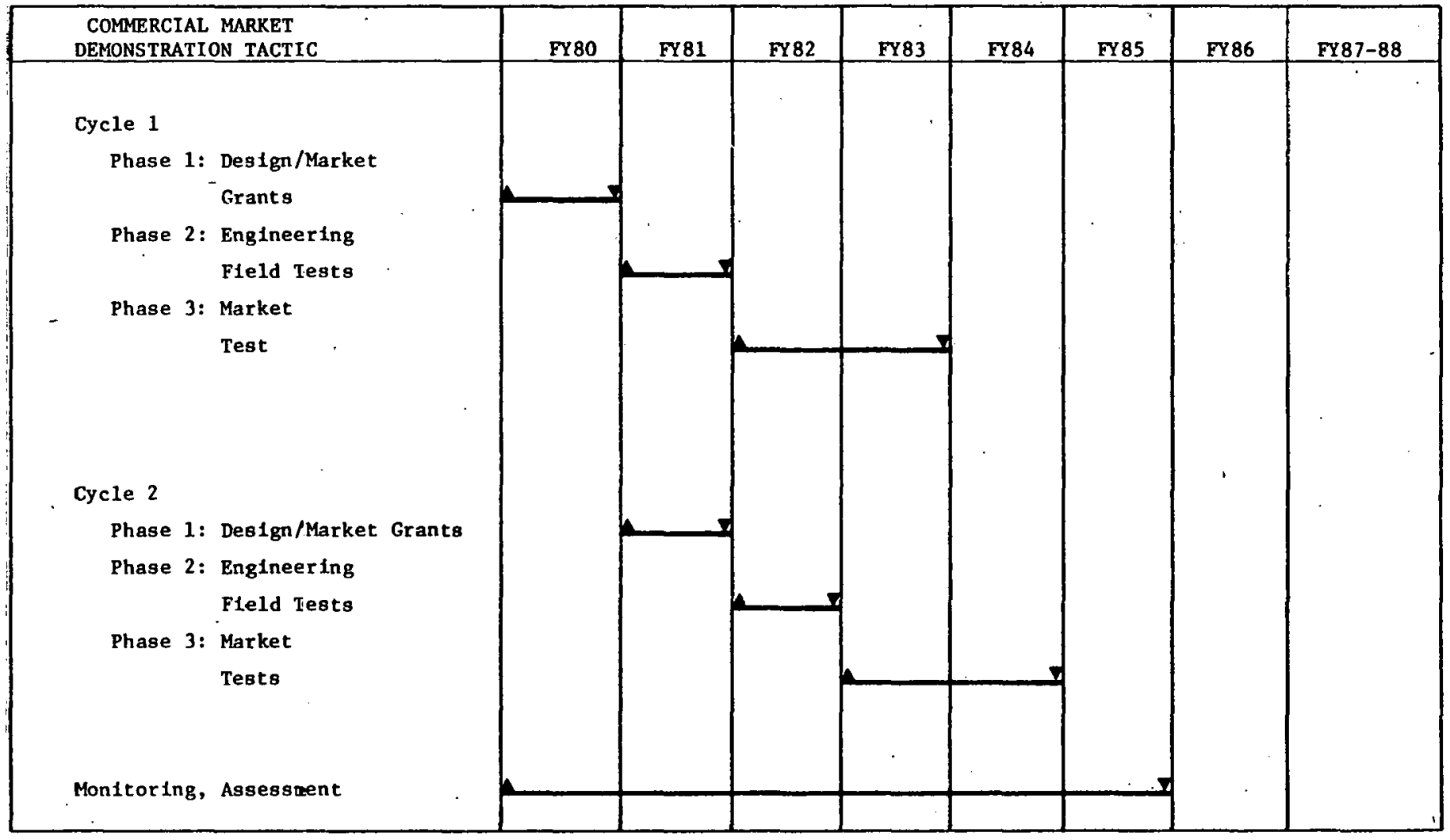

Figure 3-1. Commercial Market Demonstration Tactic Timing 
effort. One requirement of the marketing plan, necessary for participating in future phases, is the identification of users in specific markets that would be willing to costshare market tests built in phase 3. Companies must also establish affiliation with a local systems company, or iginal equipment manufacturer, installer, or other local company in the regions where they anticipate selling their systems. It is estimated that ten companies will participate in cycle 1 , phase 1 , and twenty-five in cycle 2, phase 1 .

3. Phase 2 of each cycle is the engineering field tests. DOE begins by reviewing marketing plans of phase 1 contractors. DOE then funds engineering field tests (EFTs) of approximately three system designs for each company with acceptable marketing plans that have identified photovoltaic applications and markets with good commercial potcntial. Most of the EFTs arc built in the United Etates by participating companies, and initial operation is closely monitored.

4. Phase 3 of each cycle concerns market tests. This phase begins with a DOE review of the initial results of the EFTs. Companies with viable systems in phase 2 are awarded two-year cooperative agrcements to construct market tests in the markets specified in phase-1 marketing plans. Companies are required to build systems for users who are willing to cost share systems. Companies must also work with a local systems company, equipment manufacturer, or distributor. In bidding on phase 3 projects, companies are allowed to bid fixed numbers of systems they would like to biild at prespecified prices. Companies may be funded to build as many as 75 systems, depending on the system sizes and costs proposed.

5. Companies are required to report results of the demonstrations one year after completion of the phase-3 effort. The extent of commercial sales related to these market field tests must also be reported.

To insure industry competition, the results of all design and market grants and market tests will be made publicly available through the information clearinghouse and other appropriate infor mation dissemination channels. It is also possible under this tactic that several companies will conduct market studies and market tests in the same countries if more than one company expresses an interest in a particular area.

\subsubsection{Discussion and Rationale}

The commercial market demonstration tactic is designed to maximize the participation of U.S. industry and the direct contact of U.S. industry with potential customers and with foreign companies that will be needed to install and service photovoltaic systems in foreign markets. This tactic is responsive to the recommendations of experienced industry representatives and the results of studies that examine the role that demonstrations can play in the commercial development of a product. The workshops of export industry marketing representatives conducted to support the preparation of this plan (see Appendix F) stressed the importance of encouraging the direct marketing efforts of U.S. companies. Marketing planning grants combined with market tests enable companies to learn about viable market opportunities and to design and build systems that will respond to these opportunities. According to these experts, no one is better prepared to expand exports of photovoltaic systems to commercial markets than private companies. The most effective actions that the U.S. government can take are to tap the resources of private companies by complementing the market development process that would be followed by these companies. 
Interviews with photovoltaic industry representatives also emphasized the importance of encouraging industry market experience through government-funded demonstration projects that provide contacts between U.S. companies or their local affiliates and potential users or installers, and test photovoltaic systems under realistic market circumstances (see Appendix E). Companies interviewed felt that direct government involvement in demonstrations in international markets should be minimal.

Studies of the results of past U.S. demonstrations programs for various technologies also support the features of the approach to be followed in the commercial market demonstration tactic (Baer et al. 1976; Charpie Task Force 1978). These studies suggest that demonstrations can be most effective when the technology is well in hand, when costs and risks are shared by nonfederal participants, when projects take advantage of existing industrial capabilities, and when projects are initiated from nonfederal sources. Photovoltaic systems for most international applications represent off-the-shelf-hardware. Both industry and potential users will cost-share parts of this tactic. Industry and users are both optimistic about the market for photovoltaics, have initiated numerous projects on their own, and continue to advocate new projects and programs. Effective demonstrations also have been shown to be only one part of a larger, integrated federal effort to stimulate commercialization-an essential principal of the international photovoltaics program.

A study of the availability of financial resources for purchasing photovoltaics in foreign countries (conducted to support this plan, see Appendix G) found that two-thirds of all development projects today in countries with high market potential for photovoltaics are funded through commercial channels. The role of commercial financing in industrialized countries is even more prominent. The development market tactic (tactic 2) addresses an important sector of the international market in which public institutional and concessionary financing dominate. However, commercial markets in which commercial financing is available, appear to be the largest source of funds for photovoltaics and the largest potential markets. An analysis of projects in agricultural and energy development projects funded by various commercial sources indicates substantial market opportunities, financing, and interest in photovoltaics exists.

A three-phased approach in the commercial market demonstrations is used to take advantage of industry market and product development expertise, and at the same time provide some government control to ensure that systems operate effectively and that marketing plans are politically and economically realistic. The three phases also correspond closely to the steps in the product development process.

Two cycles are to be conducted to allow for diverse company participation in the tactic. Companies not prepared to participate in the first cycle will have the chance to participate in cycle 2. Companies participating in the first cycle would be eligible for cycle 2, but new participants will be given preference.

The design and market grants in phase 1 permit a company to perform in-depth market research and to make initial contacts with potential customers and local companies. These market studies may be the most effective way to supply the photovoltaic industry with new and useful market information. The experience of both market experts and the photovoltaic industry suggest that this direct contact with a market by interested companies is more helpful than government-funded, publicly available market studies. The reason for this is that marketing grants permit a company to analyze a market from its own perspective and to address questlons relevant to its own sales position in specific markets. Each company is likely to have different geographic and product interests and 
marketing approaches, all of which cannot be adequately covered in large, publicly available studies. Market information collected by a company for its own use is the type of information on which a company will base its marketing decisions. More general studies cannot substitute for this market research.

Marketing and design grants (phase 1) will be awarded to approximately 10 companies in cycle 1 and 25 companies in the later cycle. The exact number will depend on the extent of cost sharing offered. Bidding companies must be affiliated with U.S. manufacturers of photovoltaic modules. Possible criteria for selection may include the position of the bidding company in international markets, experience with photovoltaic systems and commitment to commercial photovoltaic products. Phase-1 agreements will cover less than a one-year term. Upon completion, companies will be required to submit a summary of their marketing plan and a description of the photovoltaic system designs that they plun to market.

Companies that complete phase 1 may be awarded cooperative agreements in phase 2 to construct engineering field tests (EF"I).* Completion of phase 1 would not uuluirulically qualify a company for participation in phase 2. Selection for phase 2 would be based on the appropriateness of the marketing plan and the probability that the proposed system designs will satisfy the market identified. EFTs serve several purposes. They prove that construction of an operational system is possible and that no technical problems with the system exist. EFTs also indicate what actual system costs and performance will be. EFTs related to international markets are important because they provide visible proof to foreign customers that similar systems have been successfully constructed in trie United States and that these systems are in use and work. EFTs can also serve as a focal point for educating foreign visitors as part of the purchaser assistance program element. (See Section 4.4.)

Approximately three EFTs will be built by each contractor in phase 2. About 10 companies are expected to build EFTs in cycle 1 and 20 companies are expected to build EFTs in the later cycle. The slight attrition of contractors from phase 1 to phase 2 will result from loss of interest by a few companies and unsatisfactory phase 1 results. Thirty EFTs would be built in cycle 1 and 60 in cycle 2, with an average system size of 5 $\mathrm{kW}$ /system. (Company cost sharing would allow möe engineering fleld tests lu be constructed.) This number is believed to be sufficient to prove that market tests built under phase 3 are technologically feasible and to identify any basic flaws in photovoltaic system designs.

Although most of the engineering field tests will be built in the United States, contractors will have the opportunity to propose that EFTs be built overseas. A proposal to build an EFT overseas will be accepted if the test is in a setting that clearly shows it is an engineering experiment and not a demonstration. Research laboratories, research centers, or universities would be prime candidates for overseas engineering field tests.

Building the majority of EFTs relevant to international markets in the United States will demonstrate U.S. approval of photovoltaic systems. But these EFTs will not provide a convincing demonstration to potential foreign customers that photovoltaics can effectively meet the needs of their specific application in their own environment. While EFTs are technologically and thus experimentally motivated, MFTs are exemplary and commercially motivated. The Charpie Task Force Report to DOE on demonstrations states

*In some cases, it may be possible to skip the engineering field test if a company has already demonstrated that a proposed system has operated effectively in the U.S. 
that a well defined separation between "experimental" and "exemplary" projects is needed, and that exemplary projects should be pursued if the ultimate objective of the program is to influence commercial decision makers (Charpie Task Force 1978).

It is expected that contractors participating in the engineering field tests will also participate in phase 3 of the commercial market demonstrations. In phase 3 , each contractor will build multiple market field tests in foreign locations. The specific systems and locations in which these systems will be built will be determined by participating companies. Companies will be required to solicit cost sharing from users of these systems, and to specify the degree of user cost sharing in their phase-3 bids. Cost sharing by users has been shown in previous studies to be a critical element of demonstration projects which have been successful in promoting diffusion of the new technology (Baer et al. 1976).

Another consideration in the approach to phase 3 is the impact that demonstrations have on the production capability of photovoltaic system suppliers and module manufacturers. A recent study of the effectiveness of alternative photovoltaic procurement strategies in motivating companies to improve module and systems technology and reduce costs found that multiyear contracts for substantial numbers of systems would help suppliers simplify system designs and implement production advances (Costello and Posner 1979). For this reason, phase 3 contractors will last two years. Companies will be asked to bid a specific number of systems to be built at predetermined prices. Companies may submit alternative bids. That is, they may bid a large number of systems at low prices and a smaller number at higher prices. This technique will encourage companies who believe that they can reduce costs through larger purchase quantities to do so. Awards for phase 3 systems will be distributed among bidding companies according to the relative prices quoted by different companies and the availability of phase 3 funds. Companies with lower prices and larger quantities will be given large awards. However, all qualified companies will be awarded contracts for at least a few systems. This approach will maintain a competitive industry at the same time that companies with more aggressive production plans will be rewarded. Companies should receive larger contracts for lower prices which are based on real production improvements, not efforts to buy market share.

In the recommended budget option (Sec. 6), the average number of systems built by a single company in phase 3 would be approximately $255 \mathrm{~kW}$ systems. User cost sharing in each company's phase-3 bids would permit a larger number of systems to be built. Several companies may build up to 100 systems depending on the size and prices of systems bid. Mure than 600 systems $\left(5 \mathrm{~kW}_{\mathrm{p}}\right)$ will be constructed in phase 3 of the commercial market demonstration tactic under the recommended budget. This number of systems will result in broad exposure for a wide variety of systems and applications built by numerous companies in many different markets and regions. The results of these projects will be the basis of purchaser decisions on whether or not to select photovoltaics and U.S. components and systems in many commercial markets through the 1980s. If the program is successful, commercial users will independently select U.S. photovoltaic systems over other power alternatives and over products produced by other countries. The U.S. market share of the international market will increase and the world wide sales of photovoltaic systems will also increase.

\subsubsection{Program Element 1, Tactic 2: Development Market Demonstrations}

\subsubsection{Tactical Objcetive and Summary of Approach}

The objective of this tactic is to prove photovoltaic systems in uses relevant to development, and to convince international development and financial organizations that 
photovoltaic systems are viable and applicable in developing countries. If AID agrees with the plan, the approach would be as follows:

1. Identify ongoing and-planned AID development programs and projects in which photovoltaics could substitute for other energy sources (begin in FY80; repeat in 1981-1984).

2. Select one central bureau program and 8-15 country mission projects (ongoing or planned) for inclusion of photovoltaics (begin in FY82; repeat in 1983-1986).

3. DOE provides AID with funds and, as necessary, technical direction for technology evaluation of existing photovoltaic projects, and provides system performance requirements for selected program/projects (begin in FY80; repeat evaluation of existing projects in 1981-1988; repeat assessment of requirements in 1981-1984). DOE application projceto construoted in FY80 and FYRI in remnle slundudume piogram managed by NASA-Lewis sliuuld also be examincd.

4. AlD conducts evaluations arid specifies system performanoe requirements for integrating photovoltaics in selected projects on the basis of local conditions and development needs.

5. DOE provides AID with funds to construct selected photovoltaic systems.

6. AID, assisted by DOE as necessary, issues requests for proposals (RFPs) for photovoltaic systems (beginning in FY81 and repeated in 1982-1985).

7. Designs assessed by AID (with technical assistance from DOE) and selected proposals for system purchases are funded (beginning in FY82; repeated in 1983-1986). Systems are installed in field sites.

8. AID monitors performance and impacts of systems and provides documentation of project performance to LUE (beginning in FY82; lejpeated 1983-1988).

9. AID ensures that projects which are operative in the field are utilized as demonstrations for other international development and financial organizations and for developing country governments through site visits and dissemination of information (beginning in FY82; repeated in FY83-88).

10. In FY82, cycle 2 of development market demonstrations begins (with step 2 above). A total of five cycles are conducted with each cycle beginning one year af ter the previous cycle.

The timing of the development market demonstration tactic is deteribud in Figure 3-2.

\subsubsection{Discussion and Rationale}

Developing countries have a significant definable need for photovoltaic systems, and constitute a significant potential market for photovoltaics. Photovoltaic systems will become increasingly cost effective in many applications in developing countries in the near future for two reasons. First, these countries have development needs in remote locations which require small-scale electric sources. Many of these needs cannot be met cost-effectively by conventional electrical technology. Photovoltaic systems can be 


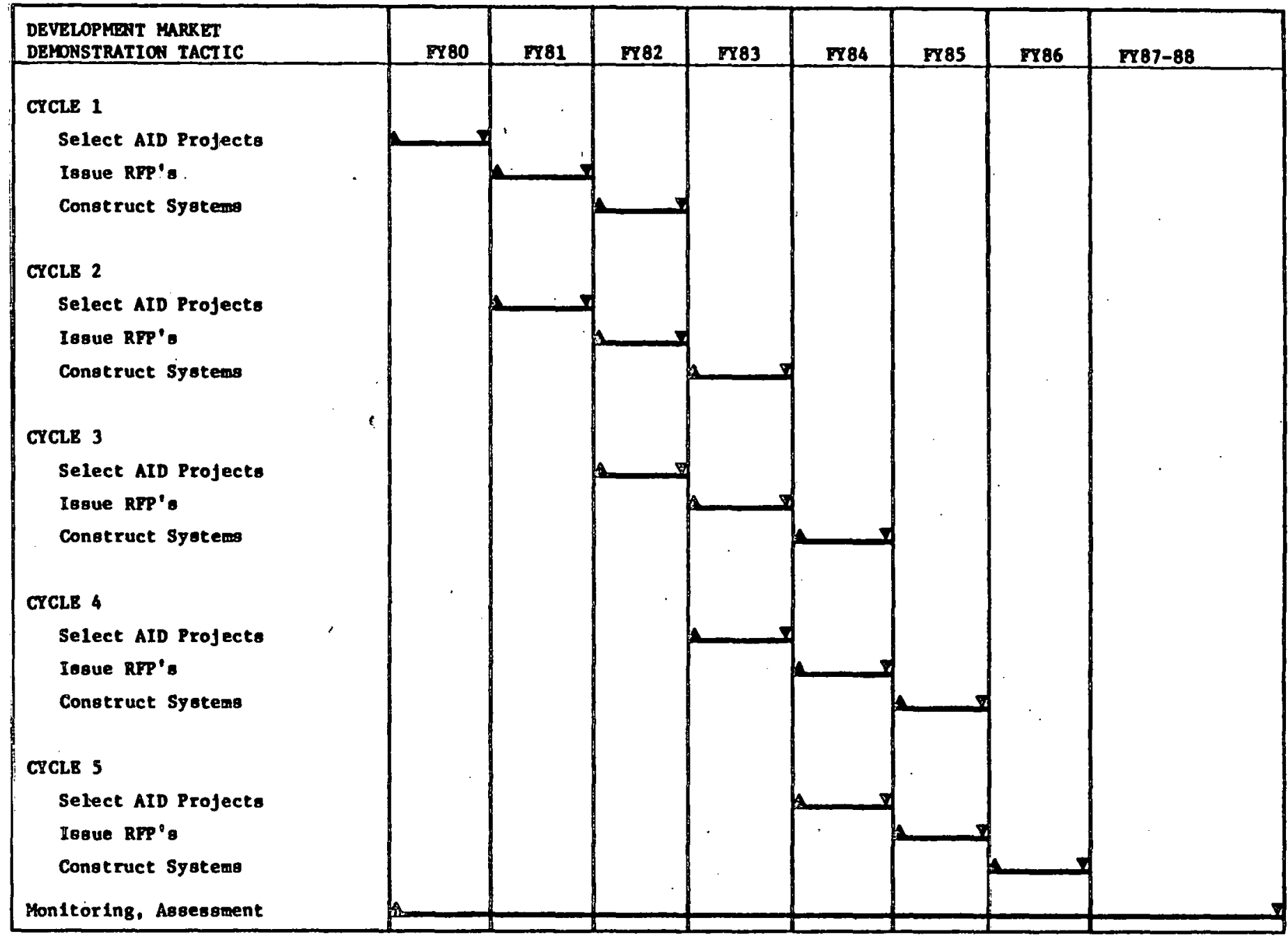

Flgure 3-2. Development Market Demonstration Tactic Timing 
sized to meet specific local conditions and these systems do not require continuous fueling or extensive maintenance. Second, many developing countries lack the foreign exchange to continue to import sufficient petroleum to meet their development requirements and lack the infrastructure for appropriate and reliable distribution of petroleum fuels and grid electricity.

An analysis of future development projects in many countries suggests that substantial quantities of investment funds from international financial institutions, development agencies, as well as commercial banks will be devoted to projects which might use photovoltaics (see Appendix G).

Demonstrations and field tests of photovoltaic systems in developing countries, in conjunction with existing programs, will provide rapid information feedback to the U.S. photovoltaic industry on system design and operation. Demonstrations funded by the U.S. government will provide an initial boost to the photovoitaic industry and are likely to stimulate additional purchases, in the short and midterms, by foreign governments-often funded by international financial institutions-and by international development organizations. These potential buyers of photovoltales must have the oppor'tunity to acquire technical and evaluative. information about the viability and applicability of photovoltaics in development contexts before they will undertake their own, independent purchases and uses of photovoltaic systems. Carefully designed and rigorously evaluated and documented demonstration projects can supply this information. (See Appendix $G$ on the programs and priorities of international financial institutions.)

Development market demonstrations will have the important added benefit of making immediate contributions to ongoing U.S. foreign assistance programs in the areas of agriculture, education, health, rural economic development, and energy. They are likely also to facilitate the development of some new projects which would not be feasible using conventional energy sources, such as remote medical facilities with adequate refrigeration equipment. The type of demonstrations envisioned should enhance the effectiveness of U.S. foreign assistance programs and their positive political, economic, and social impacts.

AID may be the appropriate federal agency to conduct and oversee technology demonstrations in those countries that are AID recipients. AID has the Congressional mandate and primary responsibility for assistance programs. It also has the requisite information, steadily increasing experience, and necessary relationships with foreign governments to conduct demonstrations. Further, AID is the major federal agency with ongoing and planned projects utilizing photovoltaies.*

AID is empowered to draw on and coordinate its efforts with other agencies of the federal government by means of Participating Agency Service Agreements (PASA) and Resource Services Supporting Agreements (RSSA). Currently, AID has a general purpose RSSA with DOE for information and assistance in certain energy areas. These agreements will be used as needed to implement the development market demonstration program.

* Over the duration of the program, some of the AID activities in the development market demonstrations may be transferred to the newly created Institute for Scientific and Technological Cooperation which is expected to assume responsibility for certain AID research functions. 
A programmatic emphasis on energy-and especially on nonconventional energy resources -has recently developed in AID. A survey of ongoing and planned AID projects (June 1979) reveals 11 projects in which photovoltaics are a component or main focus. (See Sec. 1.3.3.)

The average time between project conception and beginning implementation of a project in AID is about two and one-half years. To reduce the time lag for the photovoltaic demonstration program, it is important to begin the program quickly and to endeavor to substitute photovoltaics for other electrical sources in ongoing and planning-stage projects and programs, especially in 1980 and 1981.

Because of the organizational structure of AID, it would be necessary to distinguish in the selection of demonstrations between central-bureau programs and country-mission programs and projects as specified in step 2 of the approach.

Most AID programs and projects are not directly focused on energy. Rather, they are concerned with development needs in the areas of health care, agricultural development, education and rural community development. Not all such projects require new energy sources. Those projects for which a new energy source is needed subsume the concern with energy technology on considerations of cost, local conditions, and applicability of the energy source to the development need. Therefore, in structuring the demonstrations, it would be necessary to select from among possible projects those that can most usefully and effectively integrate photovoltaic systems with development goals and local circumstances. Careful selection of appropriate and feasible programs and projects for the demonstrations is the key to successfully meeting the tactical objective.

All activities of AID that fall under the mandate of the international photovoltaic program plan, and that directly concern the technology evaluation and system performance aspects of the international development of photovoltaics, should be funded by DOE as indicated in step 3 . DOE has responsibility assigned by Congress to carry out all aspects of energy programs, as well as to coordinate U.S. international energy initiatives. Moreover, AID does not have funds available to independently run a program of the nature and scale of the one outlined here. Because AID staff generally do not have the expertise to undertake the more technical aspects of assessment suggested in this program, DOE would coordinate efforts with AID and provide AID with technical support as needed. Systems experiments supported by DOE in the Remote Stand-Alone Program, as well as AID systems, should be used to evaluate concepts and applications for use in subsequent years under this tactic (NASA-Lewis, July 1979).

Although AID would draw on technical support from DOE and others, AID itself would generate the system performance requirements and perform evaluations and selections, because these steps must be carried out in a full context of local environmental and social conditions and development needs (step 4). In undertaking evaluations and specifying performance requirements, AID, in addition to posing technical performance questions, will focus especially on the issue of integration of the photovoltaic power system with the jurposes and gouls of development projects. Entire projects must be successful in these demonstrations, not just the electrical generation components, and system performance specifications must, therefore, go far beyond power levels or hardware characteristics.

Once demonstration projects have been selected and assessments completed, AID, with the assistance of DOE, will issuc RFPs for the first cycle of systems. The RFPs will be addressed to both photovoltaic module manufacturers and to original equipment producers. They will emphasize that designs submitted must already be proven in engineering 
field tests. RFPs will also emphasize the importance of effective integration of photovoltaic components with the overall project.

Before proceeding to assess the designs proposed, AID will establish a method of evaluation of proposals, including such factors as cost, technical assessment of the design, suitability to the development needs of the selected projects, and potential generalization and marketability of the design. The proposed designs will be evaluated independently by AID, DOE, and the office managing the international photovoltaic program. AID and the DOE/Program Office will then correlate the evaluations and select designs for implementation.

In addition to funding the costs of photovoltaic systems, DOE must be prepared to provide performance support to AID if needed. Since most of the AID demonstrations will not be energy projects specifically but rather will be parts of broader development projeets, suppurt und back-up for problems of performanoe of the photovoltair syjsems must be available. AlD's development projects cannul be pelmitted to fail altogether should difficulties arise with the power generation equipment.

Step 7 of the approach specifies that the first cycle of photovoltaic systems will be installed in field sites in FY82. Installation will include more than just physical placement of the equipment. AID, DOE, and the equipment contractor jointly will prepare materials for user education and maintenance training; each system design will be accompanied by a user manual and operation and maintenance instructions in appropriate languages. Further, prior to and concurrent with each installation, local technicans will be trained in installation and operation procedures, and local users will receive training, to the degree necessary, in the nature of the system and its utilization and maintenance.

At each demonstration site, AID will coordinate with the equipment contractor to monitor the condition and performance of the photovoltaic system, beginning with the initiation of operation. Routine monitoring will be conducted by local users; additionally, periodic inspections of equipment will be made by the contractor. Monitoring will include recording of technical data on performance of the system and detailed information on any malfunctions. These data will be provided to the information clearinghouse.

In addition to monitoring system performance, AID will conduct systematic evaluations of the social, economic, and environmental impacts of all aspects of the photovoltaic system, its contribution to the larger development project of which it is part, and user response to the system. Special attention will be devoted to documenting the effects of local maintenance and management of the system.

Although the last new demonstrations will be installed in FY86, all demonstration systems will operate in conjunction with the AID programs for at least one and, more commonly, two years. Selected demonstrations may be monitored for longer term performance (5-10 years). Therefore, monitoring and assessment of the demonstrations will be continued at least through FY88.

All systems installed in the development markets will be proven in the United States prior to their use by AID. Only off-the-shelf components and system configurations that have already been proven through engineering field tests will be allowed in this tactic. In spite of this requirement, the first two months of operation of each demonstration project should be viewed as a test period, during which the project is monitored intensively and modified if necessary. 
The combination of the duration of the development market demonstration tactic and the time required for design, installation, monitored operation, and evaluation of projects makes it possible to undertake five cycles of projects; i.e.; five years of initiation of projects. Wide geographic distribution of projects and diversity of technology and of applications are desirable to ensure that these projects fulfill the requirements of the law and their functions as demonstrations. Over the five cycles, a total of 45-80 projects will be carried out-sufficient to provide at least one project in every region with AID missions.

\subsubsection{Program Element 1, Tactic 3: Nongovernment Organization Market Demonstra- tions}

\subsubsection{Tactical Objective and Summary of Approach}

The objective of this tactic is to familiarize nongovernment development assistance organizations (NGO)* with the capabilities of small-scale photovoltaic systems for use in agricultural and health needs. Figure 3-3 describes the timing of this tactic.

The approach is summarized in seven steps:

1. Representatives of selected nongovernment organizations meet to define technical characteristics required for small-scale photovoltaic systems to be helpful in the context of their current international programs in agriculture and health (FY80).

2. DOE, assisted by other appropriate organizations, writes and issues requests for solicitations for photovoltaic system designs that meet NGO requirements (FY81,82).

3. NGOs with DOE assistance, review designs and select those that are the most applicable and most promising (FY81,82).

4. DOE enters into cooperative agreements with NGOs for the construction of selected systems. The amount of funds to be provided to participating NGOs will be determined prior to the selection of promising systems.

5. NGOs contract with photovoltaic suppliers for the systems (FY81,82).

6. NGOs place the systems in locations they and their host countries feel are appropriate.

7. Future sales of systems or other products to NGOs and other potential purchasers in host countries are the concern of the photovoltaic industry.

\subsubsection{Discussion and Rationale}

Like AID, NGOs direct their efforts to the poorer sectors of developing countries, emphasizing programs to improve health, agriculture, education, and local economic

\footnotetext{
*These organizations are also referred to as voluntary organizations.
} 


\begin{tabular}{|c|c|c|c|c|c|c|c|c|}
\hline $\begin{array}{l}\text { MONGOKERMMMAT ORGAN- } \\
\text { IZATICR DLMONSTRATION TACTIC }\end{array}$ & Fr80 & Fr81 & FY82 & Tr8: & FY34 & Fr85 & Fr86 & FY87-88 \\
\hline $\begin{array}{l}\text { MCO' a Define Techatcal } \\
\text { Requlrements and Intereat }\end{array}$ & 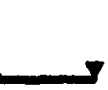 & & & & & & & \\
\hline DOS IAsues RFP & & $\mathbf{J}$ & & & & & & \\
\hline Syatem Conatructed & & & & & & & & \\
\hline Monftoring, Asuessment & & & & & & & & \\
\hline
\end{tabular}

Figure 3-3. Nongovernment Organization Demonstrallon Tactic Timing 
conditions. The impact of these organizations has been extremely great in the developing world. According to a recent release from the William Carey International University: "To this day, voluntary associations of all types and varieties, religious and secular, self supporting and philanthropic, exercise an influence all out of proportion to their physical size in the international scene. Unbelievably, they account for founding of $85 \%$ of all the schools in Africa, and until recently the vast majority of all medical and agricultural research centers in the nonwestern world" (1979). A small sample list of these organizations is presented in Table 3-2. NGO programs offer an opportunity to demonstrate the viability and applicability of photovoltaics in less developed countries. Moreover, NGO's themselves are a potential early market for photovoltaic systems. In addition to employing photovoltaic equipment in their assistance programs, some of them will also find photovoltaics appropriate for powering their remote field facilities (especially health care facilities).

Table 3-2. EXAMPLES OF U.S. NONGOVRRNMENT ASSISTANCE AND VOLUNTARY ORGANIZATIONS REGISTERED WTTH THE ADVSORY COMMITTEE ON VOLUNTARY FOREIGN AID (AID)

The African American Institute

American Bureau for Medical Advancement in China, Inc.

The Agricultural Development Council, Inc.

Agricultural Missions Foundation, Ltd.

American Dentists for Foreign Service, Inc.

American Friends Service Committee, Inc.

The Asia Foundation

Catholic Relief Services - U.S.C.C.

Community Systems Foundation

Cooperative for American Relief Everywhere (CARE)

Inter-American Development Institute

International Executive Service Corps.

Operation Bootstrap - Tanzania

Save the Children Federation

Volunteers in Technical Assistance (VITA)

World Relief Commission, N.A.E.

The concept of funding market tests for and by NGOs is a new one. Although the funding required for this program is limited, it will enable NGO demonstrations that both complement and supplement the development market and commercial market demonstrations. NGO demonstrations complement the other tactics in the following respects: (1) most of the photovoltaic systems that the NGOs will install will probably be prototype systems (their installation will constitute a form of field testing); (2) NGO applications will focus strictly on small-scale systems and their uses in health and agriculture; (3) some of the NGO demonstrations will be placed in countries in which AID has no mission; and (4) management of these demonstrations will illustrate the fact that diverse kinds of organizations can successfully operate photovoltaic systems and adapt them to their own defined needs. The NGO demonstrations will supplement the other tactics because they will contribute to increasing the exposure that photovoltaics receive in developing countries; they will contribute to the positive effects of photovoltaics in development projects; and they will help link photovoltaic knowledge and experience into the infrastructures and information networks of the NGOs abroad. 
The approach to demonstrating photovoltaics in NGO settings begins with an open meeting at which the representatives of NGOs will be briefed on the characteristics of small-scale photovoltaic systems useful to their health and agricultural programs. At the conclusion of this meeting, participating NGOs will be invited to submit short proposals (by individual organizations or groups of them) to DOE if they want to be considered for demonstration funding. In their proposals, the NGOs will specify as fully as possible the technical characteristics of the systems they need, and the locations at which they desire to construct these systems.

DOE and the DOE/Program Manager of the international photovoltaic program will evaluate and rank the proposals. Evaluation criteria will go beyond considerations of feasibility and soundness to include issues of innovativeness of application, nonduplication of AID photovoltaic projects, and potential for contributing to development efforts.

Nongovernment organizations are not likely to have enough staff members who are technically familiar with photovoltaics. Therefore, DOE will take responsibility for writing and issuing requests for proposals for the system design oompetition to meet NGO proposal requirements. Additionally, DOE will sereen the designs for technical soundness.

After initial screening, the designs will be conveyed to the participating NGOs, which in turn will select those they want to install. Because one feature of this tactic is to create initial contacts between NGOs and the photovoltaic industry, the NGOs will contract directly with systems suppliers for their systems. Technical advice will be made available to the NGOs at this stage by DOE. DOE will fund the NGO purchases. The prototype systems will be installed in field sites over a two-year period (FY81 and FY82). The participating NGOs will be responsible for the maintenance and monitoring of the systems. As a condition of their participation, they will be required to monitor and assess these systems for a term of at least one year of operation, and to report their findings to DOE. They will also be strongly encouraged to make their projects accessible to interested parties. Technical advice from DOE will be available on request to the participating NGOs for at least one year af ter the beginning of project operation.

This tactic is designed to introduce photovoltaics to NGOs and to help NGOs and industry to initiate relationships. Future sales of photovoltaic systems to NGOs should occur in the commercial market. Participating and other interested NGOs will be included in the information clearinghouse for the duration of the program.

\subsubsection{Program Element 1 , Tactic 4: Assistance and Coordination of Bilateral and Multilatcral Agreements}

\subsubsection{Tactical Objective and Summary of Approach}

The objective of this tactic is to provide technical support to photovoltaic demonstration projects in existing bilateral and multilateral agreements and to advise how projects in future agreements could support the objective of this plan. In Figure 3-4, the timing of bilateral and multilateral agreements in photovoltaics is shown.

The approach to be used is:

1. The international photovoltaic program office establishes contact with managers of ongoing bilateral and multilateral agreements that include photovoltaic demonstration projects (FY80). 


\begin{tabular}{|c|c|c|c|c|c|c|c|c|}
\hline $\begin{array}{l}\text { BILATERAL AND MULTILATERAL } \\
\text { AGREEMENTS }\end{array}$ & FY80 & Fr81 & FY82 & FY83 & FY84 & FY85 & $7 \times 86$ & FY87-88 \\
\hline \multicolumn{9}{|l|}{ Saudi-Solar Village } \\
\hline \\
\hline \multirow{2}{*}{\multicolumn{9}{|c|}{$\begin{array}{l}\text { U.S.-Italy Experimental } \\
\text { Systema }\end{array}$}} \\
\hline & & & & & & & & \\
\hline \multicolumn{9}{|l|}{ U.S. - Hexico Village } \\
\hline & To be & ermit & & & & & & \\
\hline Others Yet to Be & & & & & & & & \\
\hline Identifled & To be & ermin & & & & & & \\
\hline
\end{tabular}

Figure 3-4. Assistance and Coordination of Bllateral and Multilateral Agreements Timing 
2. Technical and planning support is provided, as needed, to ongoing agreements to ensure effective demonstrations of photovoltaic systems (FY80-FY88).

3. Information is collected from existing photovoltaic projects and used, as appropriate, in information dissemination activities of the international photovoltaics program.

4. The program of fice provides advice on useful projects that could be included in future bilateral and multilateral agreements on an ongoing basis (FY80-FY88).

5. Although no management changes are proposed as part of the international photovoltaics program, funds for existing and future photovoltaic demonstration projects in bilateral and multilateral agreements will be included in the budget of the program, to best illustrate the total amount of U.S. resources dedicated to international photovoltaic activities.

\subsubsection{Discussion and Rationale}

Existing and future photovoltaic demonstration projects with bilateral and multilateral agreements will be supported through this tactic. As pointed out in Sec. 1.3.2, several bilateral agreements in photovoltaics already exist. While many of these are primarily oriented toward scientific and technical information exchange (Technical Cooperation Sub-Panel 1978), a few will include jointly supported photovoltaic demonstration projects. The Saudi Arabian-United States SOLERAS program will devote a large amount of resources for photovoltaics demonstration projects. The Saudi project represents a major existing commitment to bilateral demonstrations. A joint agreement with Italy is also expected to lead to cooperative photovoltaic demonstration projects, and other joint demonstrations are anticipated in photovoltaics (DOE, January 1979).

The planning and budgeting process for future bilaterial and.multilateral agreements is, to a large extent, unpredictable. The size, timing, and nature of these agreements are dependent on the interests of participating countries as well as the complexities of international politics. Therefore, it is difficult to rely on these agreements to acquire photovoltaic market experience in particular countries. It is also difficult to estimate how many projects will be agreed to in the future and what their U.S. government funding needs will be. Nevertheless, in. addition to the photovoltaic demonstration projects already agreed to, other agreements will be signed.

This tactic is intended to take advantage of the opportunities for market and systems experience and information collection in existing and future bilateral and multilateral agreements. It should not be assumed that specific projects will be managed by the DOE/Program Office. Rather, the program of fice will interact with and support those organizations in charge of specific agreements and projects. Contact will be made with participating organizations in existing projects and an agreement for information exchange and technical support will be made. The results of applications projects sponsored through bilateral and multilateral agreements will be disseminated along with the results of other demonstration tactics. When possible, advice will be given to those in charge of existing projects concerning specific system applications and markets that promise to generate the most useful information for both the United States and other participating countries.

These same contacts will be established as new agreements develop in photovoltaics. Again, the approach will be to share information and offer technical support. In new agreements, particular emphasis will be placed on helping participating parties choose projects that result in useful information. 
Although the function of this tactic is primarily coordination with bilateral and multilateral agreements containing photovoltaic demonstrations, funds for these demonstrations are budgeted within the tactic. No matter by whom or where the actual agreement was managed, funding in the past has originated from ongoing DOE photovoltaic programs. Because the international photovoltaics program is a coordinated and comprehensive program, it is logical that funds already allocated to these agreements, as well as those allocated to future agreements, be reported as part of the program's budget.

Bilateral and multilateral demonstrations can be a useful source of information. They offer exposure of technologies to government officials. But these projects often are oriented towards research and development and projects that are many years from real market viability. The complexities of the planning process also make it difficult to depend on these projects to acquire needed information about particular systems in particular markets. Often projects resulting from agreements demand a high degree of government involvement, reducing the contact that industry has with users and potential customers and thus impairing direct information exchange.

Existing commitments to bilateral photovoltaic projects are quite substantial due to the scale of the U.S.-Saudi projects. The budgets beyond existing commitments should support several well planned future projects. These projects cannot be specified, however, because they have not been defined. Numerous opportunities are likely to present themselves. Limited funding for future projects may require that future projects be carefully selected. These limitations in future funding are, however, appropriate because of the difficulty of using the bilateral or multilateral agreement mechanism to support an effective demonstration project. Should future demands for bilateral and multilateral demonstrations exceed the funding available, and a policy decision be made that these projects proceed, then additional funding should be requested for the international photovoltaic program. Bilateral and multilateral demonstration projects should not be considered good substitutes for other demonstration tactics outlined in previous sections. Because of the unpredictable number and size of agreements and projects, there may be a tendency to support projects beyond the tactic budget by using funds from other demonstration tactics. This situation has had negative impacts on the photovoltaic program, however, and should be avoided.

\subsection{PROGRAM EIEMENT 2: SYSTEMS DEVELOPMENT}

This program element will be limited to a modest component and system development effort specific to systems intended for international markets. The DOE domestic photovoltaic program is centered around major technology development for photovoltaic modules and other system components, but much of this development work can be applied to photovoltaic systems for international markets. Thus, there is little need for an extensive development program for international systems. Most photovoltaic systems for international markets can be assembled from off-the-shelf components.

System development work, particularly in the design area, could improve performance of photovoltaic systems and reduce costs. The approach used in this plan is to encourage system design and development activities by private companies through the market demonstration program element. Some direct development work, however, particularly in the early years of the program, could stimulate developments unlikely to occur from industry participation in the demonstration programs or independent industry programs. 


\subsubsection{Systems Development Program Element Objective and Summary of Approach}

The objective of this program element is to support early system development needs unique to systems for international markets that will not be met by market demonstrations and private industry development efforts.

The approach will follow closely the approach to technology development outlined in the "Remote Stand-Alone Applications Implementation Plan" now being prepared by NASALewis Research Center as part of the DOE domestic photovoltaics program (1979). The major steps are:

1. DOE performs sensitivity studies on the balance of system components (all components except the modules) to determine areas that show the most promise for cost reduction (FY80).

2. DOE examines performance of remote stand-alone photovoltaic systems constructed to date relcvant to international markets to identify possible design improvements and system development needs (FY80).

3. Priority development efforts are selected which would improve photovoltaic systems for international applications and which are not likely to be done through other programs (FY80).

4. DOE (NASA-Lewis Research Center) initiates development work on these projects. Possibilities include development of simplified control systems and low-cost structures (FY80-FY81).

\subsubsection{Discussion and Rationale}

The approach outlined above is a summary of a program already initiated by DOE/Energy Technology. The program is to be conducted for DOE by the NASA-Lewis Research Center. This systems development will complement ongoing development work in the DOE domestic program and in industry. It will be targeted toward selected projects which, on the basis of past experience with photovoltaic systems, hold promise for performance and cost improvements but will not be initiated elsewhere. Development will focus on nonmodule, balance of system components such as structures and controls. Research will be limited to photovoltaic system components. Although improved, more efficient load devices for use in photovoltaic systems would enhance photovoltaic system economics, these development projects will not be included in llis piugram. Industry is already active in developing improved pumps, refrigerators, and other load devices. Load device development will remain industry's domain.

System development projects initiated under this program will be confined to the early years of the international photovoltaics program, FY80 and FY81. Beyond these years, development problems should be adequately addressed in the engineering and market tests conducted in the market demonstration program element. If further development beyond FY81 appears necessary, the future of the system development program element will be reassessed.

\subsection{PROGRAM EIAMENT 3: SUPPLIER ASSISTANCE}

This program element will help U.S. suppliers meet the demands of the international market. The assistance is to help U.S. industry fill a demand that is being stimulated by the other elements of the plan. 


\subsubsection{Overview of Supplier Assistance Program Element Objectives and Tactics}

The tactics that comprise this program element and their respective objectives are presented in Table 3-3. Figure 3-5 describes the timing of each of the tactics.

The first tactic-promotional assistance-is aimed at helping to promote U.S. photovoltaic products in international markets. In this tactic, U.S. photovoltaic products will be promoted as a group through the support of promotional activities by industry associations. Any company which desires to participate in an industry exhibit displaying U.S. photovoltaic capabilities would be encouraged to do so.

Table 3-3. U.S. SUPPLIER ASSISTANCE TACTICS AND OBJECTIVES

Tactic

1. Promotional Assistance

2. Market Assessment

3. Financial and Regulatory Outreach

4. Review of Federal Regulations and Tax Statutes
Objective

Help U.S. photovoltaic industry make contact with potential buyers in foreign countries.

Assist industry in gathering and assessing international market information.

Inform U.S. industry of how to take advantage of U.S. financial programs and comply with regulations.

Improve the international competitive position of the U.S. photovoltaic industry by exploring opportunities for favorable interpretation of U.S. regulations and possible changes in taxes.

The second tactic in this element of the program is to help U.S. industry identify future market opportunities. Market studies on a country specific basis are usually required before an accurate assessment of a potential market is possible. These studies are typically very costly. Federal support for photovoltaic market studies will be offered in tactic 2. These studies will be publicly available, and will complement the information assembled under the design and marketing grants of the first program element.

U.S. photovoltaic suppliers are often confused by the multitude of U.S. and affiliated organizations offering financing for international development programs and exports in general. Regulations and statutes governing exports and their relevance to photovoltaics are equally confusing. Tactic 3 will inform U.S. suppliers of financing provisions and regulations and statutes that could assist their export activities.

U.S. sales of photovoltaics internationally, like all U.S. exports, are subject to a multitude of U.S. regulations and tax statutes, agreements of multilateral trade negotiations, and other agreements. Tactic 4 will examine these regulations and statutes to identify any opportunities for favorable interpretation or modification to lower the costs of photovoltaic exports. Assessments of international competition in photovoltaics made to support this plan found that several countries are actively promoting their photovoltaic products through flexible antitrust and tax provisions. (See Appendix D.) Similar actions in the U.S. could counteract this marketing advantage. 


\begin{tabular}{|c|c|c|c|c|c|c|c|c|}
\hline TACIICS & FY 80 & FY81 & FY 82 & FY:33 & rY84 & FY 85 & FY86 & FY 87-88 \\
\hline $\begin{array}{l}\text { Pronotional } \\
\text { Assiatance } \\
\text { Industry Exh1bit }\end{array}$ & Design & & & & & & & \\
\hline $\begin{array}{l}\text { Market sosesment } \\
\text { Capaid lities Assessment } \\
\text { Country Specific Studies }\end{array}$ & & & & & Diss & at 1on & & 1 \\
\hline $\begin{array}{l}\text { F1nancial/Regulatory } \\
\text { Outreach } \\
\text { Manuel on U.S. Progrems } \\
\text { and Regulations }\end{array}$ & & & minat & & & & & \\
\hline $\begin{array}{l}\text { Review of Tax Statutes } \\
\text { and Hegulations }\end{array}$ & & & & & & & - & \\
\hline
\end{tabular}

Figure 3-5. Supplier Assistance Program Element Timing 


\subsubsection{Program Element Rationale}

One of the benefits which should result from the international photovoltaic program is the expansion of U.S. industrial capabilities in photovoltaics. Expansion can best result if U.S. companies are competitive in the international market. Analyses of international competition in photovoltaics today (Appendix D) suggest that the U.S. has a strong technological position in photovoltaics. Challenges to U.S. technology from other nations are, however, bound to occur. But the U.S. is likely to be most seriously challenged by the strength of other countries' marketing capabilities. The primary rationale behind the supplier assistance strategy is to encourage and improve the marketing strength of U.S. companies.

Sales in international markets, especially in the early $1980 \mathrm{~s}$, are likely to require expensive marketing efforts. In many markets, where the government or international financial institutions are likely customers, individuals with decision-making power may be difficult to identify. Many decision makers will have to be convinced of photovoltaic system capabilities before sales will result. This strategy will offer U.S. government help to offset marketing costs and better define markets and sources of financing.

The tactics in the following descriptions are all of modest cost. Combined with the tactics of other strategies, they offer an opportunity to U.S. industry to capture a large share of a growing international market.

\subsubsection{Program Element 3, Tactic 1: Promotional Assistance}

\subsubsection{Tactical Objective and Summary of Approach}

The objective of this tactic is to improve the competitive position of U.S. companies in international markets.

The approach can be summarized in two steps:

1. DOE funds will support the photovoltaic industry association or other appropriate groups for the construction of trade fair or other trade promotional exhibits for the U.S. photovoltaic industry (FY80).

2. Funding would also be available for attendance at selected trade promotional activities from FY80 to FY84. The U.S. Department of Commerce may coordinate this activity.

The industry association or group which receives the contract for preparing and maintaining this exhibit will be required to include materials from all U.S. photovoltaic manufacturers and systems that request to be included.

\subsubsection{Discussion and Rationale}

This tactic directly responds to the marketing problems confronting U.S. companies in making international sales. Interviews with those in the photovoltaic industry (Appen$\operatorname{dix} E$ ) and the experience of market experts with previous U.S. export ventures (Appendix F) suggest that one of the most serious obstacles to U.S. photovoltaic exports is the fragmentation of international markets and the associated high costs of marketing. 
Small businesses have the most severe problems in international sales because of limitations on investment funds for high-risk marketing efforts. In this early stage of market development, substantial investments in marketing are needed to build sales to the level where marketing costs per sale are reduced.

International trade fairs and other trade promotional activities sponsored by the Department of Commerce have proven to be successful in promoting U.S. products and could help promote photovoltaics. U.S. firms go where the customers traditionally gather-the recognized commercial trade fairs. International trade fairs and other similar trade promotion activities are one means of demonstrating and selling a product, and more than 80 general and specialized international trade fairs are held each year. The Department of Commerce sponsors an official U.S. participation in selected major international exhibitions because the cost of exhibiting on an individual basis is prohibitive. In areas where there are no suitable trade fairs, the Department of Commerce sponsors special exhibits of American products. Exhibitions are scheduled only. when in-depth research reveals excellent sales potential for the products being displayed.

Several U.S. photovoltaics suppliers have already participated in international trade fairs. Their reaction to these fairs has generally been positive. Interviews with industry representatives found that companies participating in trade fairs believe them to be a good mechanism for acquainting potential users with photovoltaics and U.S. photovoltaic products. The benefits of this exposure rarely lead directly to sales by the specific company participating. Rather, the benefits of increased awareness accrue to the whole industry. As a result, many companies are hesitant to bear the expense for trade fair participation because they do not receive the exclusive benefit of their participation.

\subsubsection{Program Element 3, Tactic 2: Market Assessment}

\subsubsection{Tactical Objective and Summary of Approach}

The objective of this tactic is to assist industry in gathering, assessing, and analyzing international market information. If DOC agrees with the plan, the approach would be as follows:

1. DOC, with assistance from DOE, assesses U.S. photovoltaje industry capabilities and the availability of photovoltaic products, and the nature of international competition (FY80 with periodic updates).

2. DOC, with direction from a photovoltaic industry advisory committee, directs country specific, publically available market studies. (FY81-FY83).

3. Results of market studies are then reported to the photovoltaic industry advisory committee and other audiences through existing DOC information dissemination channels and the infor mation clearinghouse (FY80-FY85).

\subsubsection{Discussion and Rationale}

Several studies have examined potential markets for photovoltaics over the last several years (Aerospace Corp. 1977; BDM Corp. 1977, 1978; Booz-Allen 1978; Costello et al. 1978). All of these studies have found a high degree of uncertainty in potential markets. This uncertainty is especially prevalent in international markets, in which market 
experience is limited and markets are highly fragmented. Studies of the current photovoltaic industry have found that market uncertainty is one of the most serious problems currently confronting the photovoltaic industry (Booz-Allen 1978; Costello et al. 1978). Faced with this market uncertainty, photovoltaic suppliers have difficulty making investment decisions. Poor information on potential markets makes it difficult to develop marketing plans and strategies.

Interviews with photovoltaic companies (Appendix E) indicated that most suppliers have not found existing government market studies to be very useful. The studies have been too global in scope, covering too many countries and possible photovoltaic applications. Previous studies have also focused almost entirely on the costs of photovoltaic systems as compared to alternative power sources, and on statistical estimates of market size. They have usually ignored many factors needed for a company to develop a marketing plan, such as financing availability, sales channels, and the availability of distributors and service companies. These studies have also failed to identify probable decision makers.

The approach outlined here is intended to respond to the inadequacies of previous studies, and to make future studies more useful. The intent of this approach is to assist industry in developing their own international marketing plans by performing market studies useful to them. These studies will of course provide information on international markets useful to government decision makers and help guide government-supported marketing programs. The DOC concluded market studies should complement market investigations that will be conducted by particular companies under the commercial market demonstration and promotional assistance tactics.

DOC has helped industry identify export opportunities and techniques for selling U.S. products in foreign markets since its inception in 1913. Through its various bureaus (the Industry and Trade Administration, the Bureau of Export Development, the Bureau of Field Operations, and the Bureau of International Economic Policy and Research) DOC has established an effective approach for helping U.S. companies learn more about foreign markets. The tactic will take advantage of DOC's extensive expertise in international markets.

One of the strengths of the DOC approach is the extent to which it works directly with industry. With the assistance of a photovoltaic industry advisory commitee, DOC will select six countries to conduct initial market research. The industry committee will also help guide the selection of specific applications which will be emphasized in these country-specific market studies. Studies of six initial countries will be started in FY81. Six additional country-specific studies will begin and be completed in FY82; six more will be done in FY83. Some of the key questions that will be addressed include:

1. Are there any local distributors or other companies who would team with a U.S. component supplier? How is the current competition (e.g., diesels) purchased, supplied, distributed, and maintained locally?

2. How can photovoltaics be written into a developing country's agricultural or electrification expansion plan? Who is the government contact with the power to alter those plans?

3. Are there any institutions in the country that could make industry's (or government's) demonstrations more effective in stimulating purchases?

4. Who traditionally controls the bulk of finances for capital goods purchases in the country? How much money is available? 
5. What is the foreign competition doing in the country?

6. What is the mix of applications which would be most effective in the country?

This sampling of questions indicates the kind of specificity required to develop a real marketing plan for a photovoltaic company. This information would also help in targeting of government-sponsored experiments and demonstrations as well.

The third step in this tactic will be to effectively disseminate the results of market studies to industry. The Department of Commerce will use its established information dissemination channels. For example, DOC publications such as the International Marketing Information Series and the Index to Foreign Market Reports may be useful. DOC also has approximately 60 district offices with established methods of distributing information to industry. The resources of the international photovoltaics program information clearinghouse will also be used.

\subsubsection{Program Blement 3, Tactic 3: Financial and Regulatory Outreach}

\subsubsection{Tactical Objective and Summary of Approach}

The tactical objective of this tactic is to inform the U.S. photovoltaic industry about how to take advantage of U.S. financing programs and comply with export regulations.

The approach can be summarized in a few steps:

1. The Export/Import Bank, SBA, State Department, AID, Treasury Department, the Department of Commerce and Overseas Private Investment Corporation (OPIC), with assistance from DOE, may continue to prepare manuals or other documents describing how to use government programs to improve photovoltaic marketing strategies (FY80 and FY81).

2. A summary manual would then be prepared by $D U E$ and distributed to the industry (FY81).

3. Periodic announcements of new programs would be prepared by cognizant agencies and distributed to industry by DOE. (DOE will use existing distribution facilities and channels where they exist; e.g., the Department of Commerce.)

\subsubsection{Discussion and Rationale}

Many federal agencies already have programs which could aid U.S. companies in exporting photovoltaic systems. These programs could be helpful to U.S. photovoltaic companies in financing photovoltaic systems for prospective purchasers, and in understanding how regulations governing exports can be observed without impairing their export marketing plans. The Department of Commerce, for example, offers a number of useful services unknown to many of the photovoltaic companies. These include a Business Counseling Service which supplies information on upcoming projects of international financial institutions, and sources of credit, other information on financing, and insurance. DOC also offers an Agent/Distributor Service that helps U.S. companies locate foreign import agents and distributors as well as providing a number of other programs 
that help identify promising export opportunities. The Export/Import Bank has several programs for guaranteeing international loans, for insuring loans, and for helping small businesses. Other agencies have programs that could also help photovoltaic companies.

Interviews with photovoltaic industry representatives (Appendix E) found that companies currently are confused by available financing programs, export regulations, and the role that the U.S. government can play in facilitating export activities. A large amount of time is required for individual companies to decipher these programs and regulations. :To take advantage of existing and future financing programs and to learn quickly how to deal with regulations, photovoltaic companies would benefit from a single source of information. As new programs become available and new regulations are adopted, companies will be informed under this tactic.

\subsubsection{Program Element 3, Tactic 4: Review of Export Regulations and Tax Statutes}

\subsubsection{Tactical Objective and Summary of Approach}

The tactical objective is to facilitate the international competitive position of the U.S. photovoltaic industry by exploring opportunities for favorable interpretation of U.S. export regulations and tax opportunities.

The approach is outlined in two steps:

1. The program management office, in coordination with the agencies, could study and review tax statutes and foreign trade regulations (FY81).

2. The Federal Trade Commission (FTC) and the Departments of Treasury and Justice could work with the DOE/Program Office in evaluation and recommendations relating to tax statutes and foreign trade regulations (FY82).

\subsubsection{Discussion and Rationale}

Government regulations and tax statutes have a direct effect on the competitive position of U.S. photovoltaic companies in the international market. Analyses of international competition indicates that European countries and Japan have shown historical strength in exporting other high-technology products. While the U.S. is the world leader today in photovoltaic module exports, France and Germany have played a strong role in marketing these modules as part of complete systems through joint-venture agreements. According to some U.S. photovoltaic companies, U.S. preeminence in photovoltaic exports can be maintained by permitting photovoltaic companies to pursue licensing agreements, joint ventures, and other cooperative approaches to international marketing. While analyses (Appendix D) found that U.S. photovoltaic companies offer the lowest photovoltaic module prices on the world market, the price competitiveness of U.S. companies might be further enhanced by modification or favorable interpretation of tax laws for photovoltaic production and export.

The first step in this strategy provides for the DOE/Program Office, in coordination with the agencies, to meet with members of a photovoltaic industry advisory committee to study and review regulations and statutes affecting photovoltaic exports. The FTC and the Treasury Department could assist in the evaluation of tax statutes and foreign trade regulations and prepare recommendations. 
This meeting with government officials can give industry the opportunity to explain any existing problems with federal regulations and statutes. It is possible that no major problems currently exist and that those that do can be easily resolved. If any real problems are identified, the second step could be for FTC, Treasury, and Justice to determine whether modifications are warranted, necessary, and feasible, and to make the appropriate recommendations and decisions.

The final step calls for a review of existing tax statutes as they relate to photovoltaic export activities. The study will outline what modifications, if any, in existing tax statutes could have a positive influence on photovoltaic exports and which modifications might be feasible.

\subsection{PROGRAM EIEMENT 4: PURCHASER ASSISTANCE AND INPORMATION DISSEM- INATION}

Before photovoltaic systems will be used extensively in international markets, potentiul purchasers must become more informed about the performance and economics of these systems and their ability to meet user needs. 'This program element will provide information to potential users through information and education tactics.

\subsection{Overview of Purchaser Assistance Program Element Objectives and Tacties}

The tactics that make up this strategy and their respective objectives are presented in Table 3-4. Figure 3-6 describes the timing of the purchaser assistance tactics.

Table 3-4. PURCHASER ASSISTANCE AND INPORMATION DISSEMINATION TACTICS AND OBJECTIVES

\begin{tabular}{cl}
\hline \multicolumn{1}{c}{ 'l'actic } & \multicolumn{1}{c}{ Objective } \\
\hline 1. Foreign Visitor Program & $\begin{array}{l}\text { To inform foreign industrial and } \\
\text { government decision makers about } \\
\text { the applicability of photovoltaic } \\
\text { systems to their needs. }\end{array}$ \\
$\begin{array}{ll}\text { 2. Foreign Education and Train- } \\
\text { ing Program }\end{array}$ & $\begin{array}{l}\text { To make future foreign system } \\
\text { designers and installers more aware } \\
\text { of the capabilities of photovoltaic } \\
\text { systems. }\end{array}$ \\
$\begin{array}{l}\text { 3. U. Agency and Nongovern- } \\
\text { ment Organization Aware- } \\
\text { ness Program }\end{array}$ & $\begin{array}{l}\text { Provide information to U.S. } \\
\text { embassies, AID missions, and non- } \\
\text { government organizations about the } \\
\text { applicability of photovoltaic systems } \\
\text { to serve foreign country needs. }\end{array}$ \\
&
\end{tabular}

The education and training tactic and foreign visitor tactic attempt to build foreign buyer expertise and interest in photovoltaic systems. These tactics also encourage 


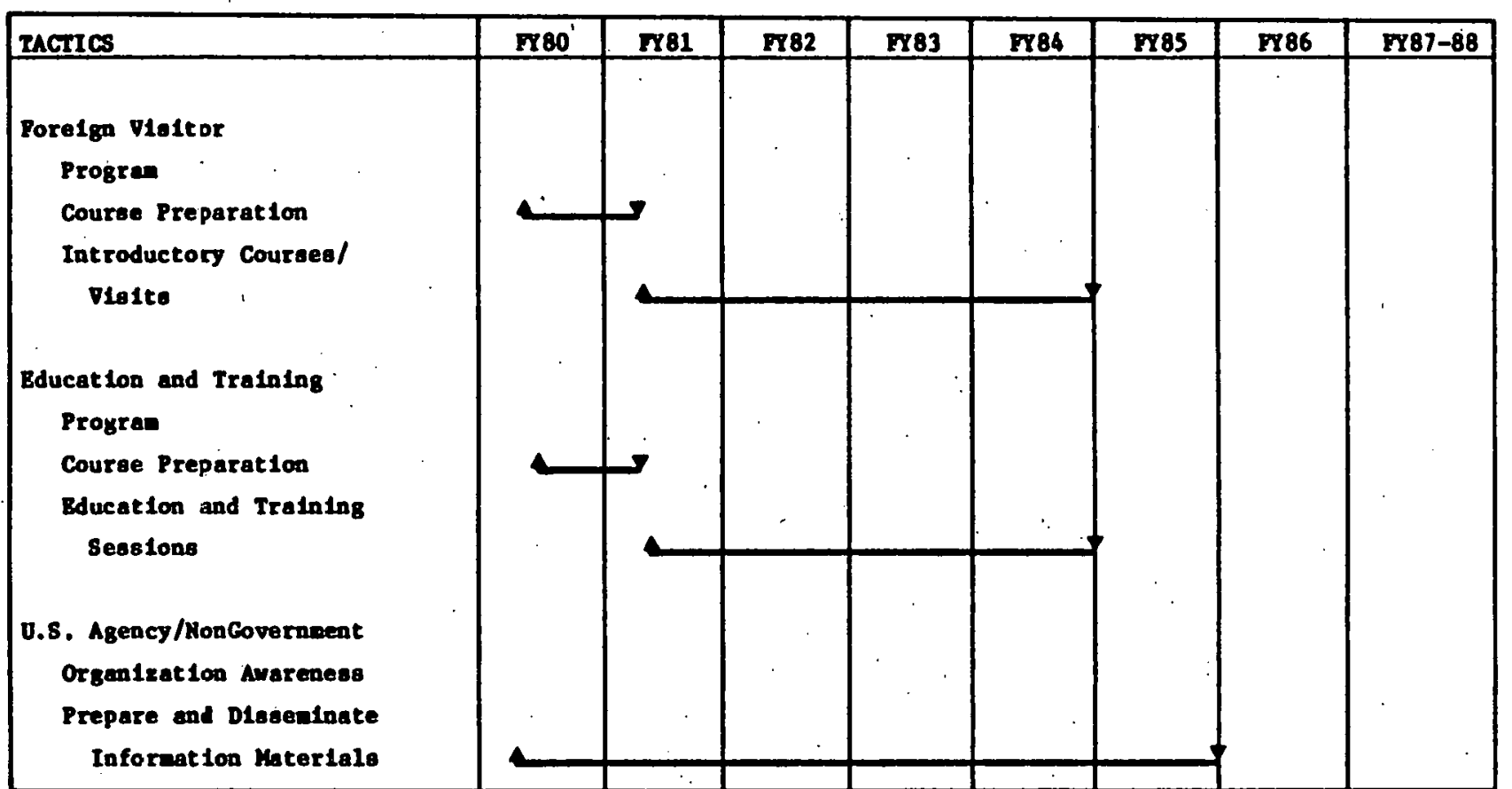

Figure 3-6. Purchaser Assistance Program Element Timing 
interactions between U.S. suppliers and foreign visitors, with the intent that potential purchasers become familiar with U.S. suppliers' products and how and where they can be obtained. This contact with U.S. suppliers was thought by U.S. export marketing experts (Appendix F) to be an important feature of a foreign education program.

\subsubsection{Program Element Rationale}

Dissemination of information to potential purchasers is an essential element of the international photovoltaics program. Purchaser awareness is a prerequisite to the diffusion of any new product in any market. International markets for photovoltaics are no different. The tactics in this program element are all low-cost efforts to improve purchaser awareness. They are designed to use existing information networks. These information programs, in addition to educating potential buyers on the cost of photovoltaic systems for specific applications, will be product oriented. That is, they will go beyond merely creating buyer awareness to assist purchasers in meeting suppliers of photovoltaic systems.

The importance of information dissemination in the international program cannot be ignored. Without an aggressive information effort, projects in other tactics would have little positive impact on market development. This tactic, and the information clearinghouse activities are necessary complements to the other program elements of the international photovoltaics program. Without them, the information collected on photovoltaic system capabilities could not be used to further the program objective.

The first tactic could use existing information dissemination networks of U.S. agencies and nongovernment organizations. These organizations have well developed techniques for supplying information to industry and government officials in foreign countries and to individual communities. Embassies can work directly with foreign government decision makers and through them with in-country information channels. AID missions have established contacts with local development organizations. Nongovernment organizations have excellent associations with local communities. All of the analyses conducted in support of this plan found a need to make information on photovoltaics available to potential purchasers.

\subsubsection{Program Element 4, Tactic l: Roreign Visitor Program}

\subsubsection{Tactical Objective and Summary of Approach}

The foreign visitor program will be established in an effort to enhance the awareness of forcign government and industry leaders with photovoltaic system capabilities. These. leaders, if convinced of the technical and economic viability of photovoltaics, could help promote their widespread use. This tactic will also inform commercial and industrial representatives, engineers with utility companies, government of ficials and others who have the capacity to assist in the introduction and marketing of the photovoltaic systems about how photovoltaics can be economically applied in foreign markets.

The approach is as follows:

1. DOE assigns responsibility for design of a short (one- to two-week) course on photovoltaic technology applications and economics. The course should include visits to U.S. demonstrations projects and suppliers (FY81). 
2. The State Department, with suggestions from other agencies, such as the International Communications Agency, and from industry, might select government and industry for participation (FY81-FY84). DOE funds the program.

In implementing this tactic, all photovoltaic companies expressing interest in seeing visitors would have equal opportunities to serve as hosts.

\subsubsection{Discussion and Rationale}

DOE will fund this visitor program and assign responsibility for conducting and administering it. The tactic consists of a few-day orientation to familiarize the participants with photovoltaic technology. Each participant will be given an information packet containing data on market studies prepared by the information clearinghouse, market demonstrations, system development test results, and U.S. photovoltaic products.

After this brief instructional session, the visitors will have the opportunity to see demonstrations of photovoltaic systems built and operated successfully in the United States. This will help convince visitors that photovoltaic systems today are technically capable of reliable perfor mance, often a determining factor to potential purchasers when selecting between alternative systems. These demonstrations should also suggest the kinds of applications in which photovoltaics have been successfully used.

The program will conclude with visits to several U.S. photovoltaic companies. These visits will help establish contacts between customers and suppliers.

The State Department could be responsible for selecting and compiling the visitors list and extending the invitations for program participation. Other program participants, and U.S. companies, may be asked to submit suggested visitors to the State Department. AID may be helpful in carrying out this program. The "Reimbursable Development Program" authorized in the Foreign Assistance Act of 1961 may serve as a model for this visitor program.

\subsubsection{Program Element 4, Tactic 2: Poreign Education and Training Program}

\subsubsection{Tactical Objective and Summary of Approach}

By helping educate those working in technical positions on photovoltaic system design and performance, a foundation of communication for the advancement and use of these systems is established. The objective of this tactic is to implement an intensive summer training program to educate engineers in technical positions of potential user institutions and system design, distributor, and installation companies on the design and application of photovoltaic systems.

The approach is as follows:

1. Contract with a university to develop an educational program on photovoltaics for foreign technicians (FY80).

2. Fund the university to conduct this program annually, with approximately 100 visitors attending when program is operating at its peak (FY81-84). 
3. State Department, AID, and U.S. photovoltaic companies could assist DOE in selecting tactic participants (FY81-84).

Like the foreign visitor tactic, all photovoltaic companies that desire to serve as hosts for visitors will have equal opportunities to receive visitors.

\subsubsection{Discussion and Rationale}

The foreign education training program will be established by awarding a grant to a U.S. university to create an education program designed to equip foreign technicians with the skills and information needed to design photovoltaic systems and choose between photovoltaics and other competitive power sources. This grant should be awarded to a university already offering an energy program with a strong emphasis in solar and in photovoltaics, and with skills in operating special education programs.

The university will set up an approximately six-week summer program. The course should include a general background in photovoltales, hands-on training in systems engineering, field applications and designs, technology assessment, and economics of photovoltaic use. The training will include a tour of U.S. photovoltaic companies and DOE demonstrations of photovoltaic systems. The infor mation clearinghouse will provide the university with updated information relevant to the course work being taught in an effort to help provide up-to-the-minute instruction on all areas of progress related to the international marketing of photovoltaics.

The State Department and AID could cooperate with the program management office to determine who will attend the program. The State Department and AID are the U.S. agencies most familiar with government and industry officials in foreign countries. Participants may also be suggested by U.S. companies marketing photovoltaics internationally. These companies, even more than government agencies, are likely to come in contact with potential users as the international program progresses. The program will be set up to accommodate 100 students/yr during its peak years, FY82-FY84. The emphasis of recruitment will be in countries with scientific and technological cooperative agreements with the United States. The United States will pay for a significant portion of the travel, tuition, and living expenses for participants. Some cost sharing by participants will be required. Cost sharing serves as a mechanism for screening seriously interested participants. It may also be appropriate to include foreign engineering students who are already studying in the U.S. in this program.

\subsubsection{Program Element 4, Tactic 3: U.S. Embassy, AID, and Nongovernment Organi- zation Awareiess}

\subsubsection{Tactical Objective and Summary of Approach}

The purpose of this tactic suggests the use of special techniques available through AID, the State Department, U.S. Embassies, and nongovernment organizations to promote the knowledge and use of photovoltaics. The objective is to promote this knowledge and use through established agencies and organizations. 
The approach in this tactic is as follows:

1. The State Department, with assistance from DOE, could prepare and disseminate information packets on photovoltaic systems and U.S. products to U.S. embassies. Embassies disseminate information in each country as appropriate (FY80-85).

2. AID, with assistance from DOE, could send "mailgrams" to country missions on photovoltaic systems (FY80-FY82).

3. Materials for use in training programs of U.S. government supported and nongovernment volunteer organizations are prepared and disseminated to appropriate organizations.

4. Special multimedia presentations are prepared by DOE and disseminated by these other agencies (FY80-FY85).

\subsubsection{Discussion and Rationale}

With the assistance of DOE, the State Department could prepare and distribute information packets to be sent to all U.S. embassies. The information packets will contain an introduction to photovoltaies and to the types of systems available in foreign countries. These packets will be updated with new data as they become available. The information will be distributed to the embassy personnel who deal directly with the energy issues of the country. These staff members will disseminate information on photovoltaic systems to the appropriate divisions of foreign governments and industrial and commercial interests with whom U.S. industry might cooperate in marketing.

AID might provide "mailgrams" to be sent to all AID country missions. The "mailgrams" would introduce and instruct the missions about photovoltaics and photovoltaic systems. This awareness program should provide a foundation of knowledge to the country missions, who in turn can introduce and instruct potential users about photovoltaics and photovoltaic systems. Interest in photovoltaics generated through AID missions could be helpful in selecting demonstration projects in the development market demonstration tactic if it is conducted through AID.

Many voluntary organizations are excellent vehicles in the integration and acceptance of photovoltaic systems, because of their direct involvement in local development projects and the technical abilities of many volunteers. A photovoltaic training packet which could be used as a part of the training programs of voluntary organizations will be prepared and made available to these organizations.

As part of this tactic, DOE and other participating agencies might also prepare multimedia presentations describing photovoltaic applications to be distributed through country missions, embassies and nongovernment organizations.

The agencies proposed in this strategy were selected based upon the responsibilities mandated in their legislation and upon their capabilities. The State Department has 138 embassies. . These embassies are a part of the Foreign Service and share in the responsibility of negotiating agreements between the United States and the country involved, explaining and disseminating official U.S. policy, and maintaining cordial relations with the country's government and people. Embassies also act as sources of information on 
U.S. industry products and services. The AID country missions have primary responsibility for generating and implementing assistance programs and projects in the less developed countries where many of the projects will be demonstrated.

Voluntary organizations direct their efforts to the welfare of the poorest people in less developed countries. These organizations can use this opportunity to demonstrate photovoltaic systems, integrate them into their programs, and for powering their remote field facilities. Information dissemination to nongovernment organizations will help support the nongovernment organization demonstration tactic as well.

\subsection{PROGRAM ELEMENT 5: INFORMATION CLEARINGHOUSE}

There is a vast amount of information now being generated relevant to the international marketing of photovoltaic systems. The projects and activities outlined in this plan and the research and commercial work of others will produce a large amount of additional information over the lifetime of the plan. This data will need to be analyzed and exchanged with industry and potential users to further economical applications of photovoltaics and photovoltaic systems technologies. The international photovoltaic program office will systematically receive and prepare this information for dissemination to agencies participating in the program, contractors, the photovoltaic industry, potential purchasers, and others. This activity constitutes the information clearinghouse program element.

\subsubsection{Information Clearinghouse Program Element Objeetive and Summary of Approach}

There are at least five types of information which the international photovoltaic program will collect and maintain. These include information on all phases of market demonstrations conducted by industrial firms, AID, and nongovernment organizations; market studies done by DOC, contractors or other organizations; results of system development tests and state-of-the-art of photovoltaic technology; program activities to monitor, control, and assess program impact and worth; and federal agency activities relevant to the plan. In addition, the program office will maintain contact with SERI's Information Center and will both provide information to the center and receive information from it. Other existing information collection and dissemination capabilities, for example those within the Department of Commerce, and will be used as much as possible.

The information clearinghouse will establish criteria for the types of regularly updated information needed by participating federal agencies, U.S. photovoltalc industry and nongovernment organizations. It will then provide information to these organizations on $a$ regular and periodic basis, so that all concerned agencles and firms are kepl up tu dute. The clearinghouse will also respond to specific requests for information by participating organizations. Because the information flow on photovoltaics will be extremely large, the information clearinghouse will screen gathered data for relevance to specific recipients of it and will tailor disseminated information to meet recipients' needs.

The clearinghouse will also prepare information packets and multimediu mulerials for U.S. information agencies, international agencies, photovoltaic-related industries, and private users in support of activities within other program elements. These will be tailored for different kinds of users and needs and different levels of technical expertise. They will be translated into appropriate languages for use in other countries. 


\subsubsection{Discussion and Rationale}

All of the analyses conducted to support the preparation of the plan suggested the need for a coordinated effort for collection and dissemination of information relevant to international market development. The information clearinghouse will serve this function. While being a focal point for information collection and dissemination, the clearinghouse will not duplicate existing capabilities but will rather use them as productively as possible.

During the implementation of the international photovoltaic program, needs for specific types of information will be better defined. The information clearinghouse should be equipped to meet these needs. 


\section{SEPI慗}




\section{SECTION 4.0}

\section{PROGRAM MANAGEMENT}

The successful implementation of the international photovoltaic program plan requires cooperation among and coordination of at least eight agencies, various DOE divisions and representatives of the photovoltaics industry; initiation of new activities in the U.S. and abroad; and the gathering and dissemination of a large amount of information. To insure that these requirements are fulfilled and the objective of the plan is met, a well thought out and vigorously carried out management plan is needed. What follows is a management plan designed to meet these needs. Its essential features include: a program officer and staff; carefully defined organizational relations and agency roles and responsibilities; a management budget; and specified lines of reporting and accountability.

\subsection{MANAGEMENT FUNCTIONS OF THE PROGRAM OFFICE}

The international photovoltaic plan legislation requires that the plan set out relevant legislation and activities of the various U.S. agencies that are now or might become involved in the international commercialization of photovoltaics. As suggested earlier, a primary rationale of this plan is to use existing agencies, mechanisms, and activities to meet the plan objective and tactical goals. The legislation also requires that the agencies jointly coordinate and formulate initiatives to carry out the objective of the plan. To meet this requirement, a SERI/JPL team met individually with the agencies to discuss what they. were currently doing and how they might contribute to the plan. These interviews yielded substantial information for the strategies contained in the plan, but also found that interagency coordination is difficult to maintain without a defined focal point. Interagency coordination is essential to plan implementation and can be sustained only with a central clearing point for information, coordination, and contract management. This coordination will be accomplished most effectively if a program office and officer-with responsibilities for liaison and coordination with other U.S. agencies and industry, reporting and review, budgetary management, first echelon procurement, oversight of hardware design, and supervision of an information clearinghouse-is established.

\subsubsection{Plan Execution and Assessment}

The plan program elements call for a wide range of activities by different government agencies and private concerns. The DOE/Program Officer must insure the proper accounting of funds, management of projects, and assessment of outcomes in relation to plan goals. The DOE/Program Office must also periodically reassess the overall program in terms of impact on the plan objective in light of changing economic and technological conditions. Therefore, in executing the plan, the DOE/Program Officer must make project monitoring a central and ongoing function of his office.

\subsubsection{Procurement Procedures}

Program Element 1 calls for several types of demonstrations of photovoltaic systems. The expenditures for hardware for the demonstrations will total approximately $\$ 106$ million, or over $70 \%$ of the monies spent over the duration of the international program. 
The Program Office will follow standard government procurement and assistance regulations. Work statements and other procurement documentation will be written to incorporate and emphasize the specific objectives of program elements and tactics. The DOE/Program Office works in coordination with AID and other agencies undertaking procurements to ensure procedural regularity, appropriate design approach, uniform accountability, and adequate participation of small businesses in procurement. It would be necessary for the Program Officer to have contracting-officer authority in order to carry out the procurement responsibilities assigned to the Office.

\subsubsection{Project Design Selection}

The DOE/Program Office will provide participating agencies with technical support in the process of design selection. It will coordinate and oversee the generation of design criteria, and will coordinate and monitor the proness of design selectlon by pal ticipating agencies. Statements of work and solicitations for design will include a list of the evaluation criteria (as established by the participating agency and reviewed by the DOE/Program Office). In all cases, these criteria will state that the system design evaluation will be primarily based on whether a given system can satisfy an identified market or need at a fixed price. The evaluation of the completed proposal review will stress this standard. Scientific and technical approach, qualifications of proposers, and past experience of the proposers will all be judged with that criterion in mind.

\subsubsection{Projeet Oversight and Assessment}

The DOE/Program Office will monitor all phases of all projects funded under the auspices of the plan. This management function will require both procedural and substantive oversight of the ongoing operation and of the evaluation of projects. (The substantive oversight will be closely interwoven with the operation of the information clearinghouse and the liaison function of the program office.)

There are at least three possible program arrangements with which the DOE/Program Officer will have to become involved in procedural oversight, project operation and assessment. These are transfers of funds for particular activities to agencies outside DOE for activities relevant to the international photovoltaic plan but a normal function of the agency; transfer of funds for photovoltaic-related contracts to agencies outside DOE; and DOE contracts or agreements for Internulionul photovoltaic activities. An example of the first type of activity is for the Department of Commerce to conduct country-specific market studies. An example of the second is an AID contract for development-related photovoltaic systems. Agreements (described in the commercial market demonstrations) entered into directly between $\nu \cup E$ and industry are an example of the third uelivity.

Program reviews necessary to insure timely and cost-effective products which accomplish the objective and goals of the program will be conducted. In the second case, where the contract manager is in another agency, the program officer will ensure, through adequate coordination, that the plan objective and specific, relevarit tactical goals are taken into account in the management and oversight of the project. Regarding instances where DOE is funding an activity of another agency and the activity is similar to that agency's ongoing activity, monitoring and assessment is provided by regular meetings between the DOE/Program Officer and agency officials, the DOE/Program Officer's presence at selected contractor reviews, and other measures whereby the DOE/Program Officer is kept up to date on the status of the activity. 
During their operation, all projects funded under the auspices of the plan must be rigorously monitored, and documentation on the quality of their operation must be periodically submitted to the DOE/Program Office. To insure adequate information on project operation, the office will include specific monitoring requirements in all contracts and agreements for projects.

During and immediately after the terminal phase of each project, the project must be subject to thorough and rigorous final evaluation, and evaluation data must be submitted to the program office for final review. To facilitate adequate and comparable evaluations, the program of fice will establish detailed evaluation guidelines, provide technical support for evaluation study design and implementation, and stipulate the requirement for evaluation in all contracts and agreements for projects. All evaluations will include attention to social and economic impacts and baseline (pre-project implementation) study, and will follow scientifically valid procedures. The DOE/Program Office will be authorized to mandate independent assessments of projects, in addition to required evaluations, as is necessary to provide needed information on project operation, cost effectiveness, social impact, commercial impact, and system design. The DOE/Program Office will utilize monitoring reports and final evaluations as bases for comparative assessments of approaches, overall program assessment, and other informational and reporting functions.

\subsubsection{Program Elements and Tacties Assessment and Reorientation}

The DOE/Program Officer is responsible for preparing an annual plan update for the program and for revising this plan as necessary. Each annual plan update will establish that year's budgetary level and specific activities within the framework of all the requirements listed in this program plan. Annual plans will also include quantitative goals to be reached to accomplish the plan's objective. These goals will be matched to and derived from the tactical goals of the plan. Preparation of the annual plans will be carried out by the DOE/Program Officer, with guidance from DOE and input from trade groups, industry representatives; and participating agencies. In addition to the annual plan, specific guidelines, directives, and agreements will be prepared in support of the plan and its subsequent revisions.

Using information from coordination work with other agencies, reports, and management of contracts, the DOE/Program Officer will assess program activities and approaches annually. Based on this assessment, guidance from DOE and other agencies, and input from trade groups and interested nongovernmental organizations, the DOE/Program Officer will analyze program progress and the adequacy of program tactics. After his assessment, the DOE/Program Officer will delineate any needed changes in the program plan and reorient the program where necessary.

\subsubsection{Budgetary Responsibility}

DOE has overall budgetary responsibility, which includes preparation of budget justification material, overall program reporting and management, and the collection and interpretation of program cost and performance.

Direct authority for these activities will be in the hands of the DOE/Program Office and this office will prepare the material needed for Congressional and DOE policy and program review. The DOE/Program Office will be assisted by the other agencies in preparation of the budget planning and justification data. 


\subsubsection{Budgetary and Funding Procedures}

The DOE Program Office will assist DOE in preparing budget information to execute the plan. In addition, the office will gather data from other agencies relating to their expenditures for photovoltaic-related activities. For those activities funded by DOE but carried out by other agencies, the office will coordinate budget preparation data with the relevant agencies.

\subsubsection{Project Accounting}

Projects necessary to carry out the program elements will be accounted for in accordance with standard government accounting procedures. Agencies outside of DOE will account for the projects they manage and furnish to the project officer the information needed.

\subsubsection{Program Budret Adjustment as Required}

As outlined previously, the DOE/Program Office will prepare and oversee the execution of the annual plan updates and the budgets. The DOE/Program Office also will gather data continuously on program execution, write assessments of program impacts, and assess program progress annually. If these assessments demonstrate the need for reorientation, the budget will be adjusted. Budget adjustment will be done in accordance with current federal reprogramming authority and with DOE guidance and approval procedures.

\subsubsection{Reporting and Review}

For proper and effective execution of the plan, the DOE/Program Office and DOE need timely and accurate information on program progress, milestone completion, and impacts of program activities. This information and other data concerning each of the program elements will be combined into the yearly evaluation of the activity. This evaluation will be used in the preparation of the Annual Program Plan Review.

Information gained from program activities will also serve many other uses. In particular, it will assist industry with system design and marketing, inform financial institutions, aid the U.S. Government in formulating policies for international commerce in other solar technologies, and contribute to the knowledge of potential purchases. Thorough reporting by participants in the program is therefore crucial to the overall success of this plan.

\subsubsection{Systematic Reporting Requirements}

The budget contains funds within the various agencies for support staff to aid the DOE/Program Office in planning, data gathering, and program and budget readjustments to meet program goals. The office will establish reporting guidelines for funded participants in the plan, coordinate reporting requirements with the agencies, and serve as the central organization for the collection, storage, and analysis of program reports. 


\subsubsection{Annual Program Plan Review}

The plan presented here is the initial program plan. It defines the program elements and budgets necessary to accomplish the plan objective. During the duration of the program, it may become necessary to modify the plan. This will be accomplished by revision through an annual program plan review. This review, conducted in coordination with DOE and the industrial and agency advisory groups, will include reports on progress of specific activities, assessment of overall program progress, and, as necessary, revisions of the program plan. It will be submitted to Congress each year.

\subsubsection{Liaison}

The DOE/Program Office will develop and maintain active coordination and communication with participating U.S. agencies and bureaus, international organizations, nongovernment organizations, and industry. It is essential that all participants have a smooth flow of information to effectively implement the plan and avoid duplication.

\subsubsection{Liaison with U.S. Agencies and Units}

To facilitate the U.S. agency liaison function, designated agencies will assign a contact officer to work directly with the DOE/Program Office. Because this contact and some agencies' participation is crucial to the plan's success (e.g., the Department of Commerce), it may be necessary to adjust a given agency's manpower ceiling to account for the added workload required for execution of the plan.

The Federal Trade Commission and Justice Department are listed in Table 4-1 as possible consulting agencies. The DOE/Program Officer will keep both of these agencies informed as to the type of contracts, request for proposals, and program opportunity notices that are to be used. In this way, these agencies can assist the DOE/Program Officer to resolve anti-trust and other legal problems before they arise.

\subsubsection{Liaison with International Organizations and Nongovernment Organizations}

Again, international organizations such as the World Bank and nongovernment organizations could become substantial sources of funds for photovoltaic system purchases. The DOE/Program Office will keep an active file and contact with these organizations to both acquaint these organizations with photovoltaic opportunities and insure that the plan is coordinated with the financial policies of the international and nongovernment organizations.

\subsubsection{Liaison with Industry}

There are at least three ways that DOE might choose to involve the photovoltaic industry in the execution of the plan. These include the use of the Solar Photovoltaic Energy Advisory Committee, as outlined in PL-95-590; the Department of Commerce mechanism that uses an informal industry advisory committee to assist that department in planning its marketing activities; and a separate committee providing input to DOE and the DOE/Program Office as to industry needs vis-a-vis the plan. The choice of which of these mechanisms to use should be left to DOE and the DOE/Program Office in consultation with participating federal agencies. The criteria for choosing the mechanism should 
include avoidance of duplicating advisory bodies, representation of a wide segment of the industry, and usefulness in advising the DOE/Program Office.

\subsection{AGENCY ROLES AND THEIR INTERRELATIONS}

A key feature of the plan is to build on present federal agency capabilities and expertise. The plan also provides a focus for coordinated federal assistance to the photovoltaic industry. The plan was evolved through the cooperation and efforts of 13 agencies. For the plan to be successful, it will be necessary to maintain interagency coordination and input of diverse agency perspectives. These requirements can best be met by the program office serving as a focus; secretariat, and continuing liaison with the agencies and by monies to be allocated for liaison and coordination acitivites.

\subsubsection{Coordinating Council}

In order to ensure adequate coordination among those federal agencies with major implementation responsibilities, a coordlnallng cuuncil, consisting of senior lcvol management personnel (Assistant Secretary or equivalent), can be designated. The coordinating council reviews the annual program plan and the members assist the Program Officer, as necessary, in implementing the approved plan in their respective agencies.

\subsubsection{Agency Responsibilities}

Each participating agency will have responsibilities under the plan. These responsibilities are detailed in the Table 4-1. The table illustrates the focus and nature of anticipated participation in different program elements of relevant governmental agencies. The numbers in the chart express the type of participation, as follows:

(1) funding agency; overall responsibility;

(2) coordination authority;

(3) direct (action) authority;

(4) cooperating agency; and

(5) consulting agency. 
Table 4-1. ACTIONS AND RESPONSIBHITIES

\begin{tabular}{|c|c|c|c|c|c|c|c|c|c|c|c|c|c|}
\hline $\begin{array}{l}\text { Program Element; } \\
\text { Actions/Tactics }\end{array}$ & $\begin{array}{l}\text { DOE/Progrem } \\
\text { Office }\end{array}$ & AID & DOC & DOD & EXIM & FTC & ISTC & JUSTICE & NASA & SBA & STATE & TREASURY & OPIC \\
\hline$\frac{\text { Market demonstra- }}{\underline{\text { tions }}}$ & & & & & & & & & & . & & & \\
\hline 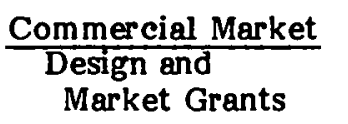 & $1,2,3$ & & 4 & & & 5 & & 5 & 4 & & & . & \\
\hline $\begin{array}{l}\text { Engineering and } \\
\text { Market field } \\
\text { tests }\end{array}$ & $1,2,3$ & & 4 & & & 5 & & 5 & 4 & & & & \\
\hline $\begin{array}{l}\text { Development Market } \\
\text { Identify, } \\
\text { select, and } \\
\text { issue RF P's } \\
\text { for AID pro- } \\
\text { jects }\end{array}$ & 1,2 & 3 & & & & & & . & 3 & & & . & . \\
\hline $\begin{array}{l}\text { Install, assess, } \\
\text { and report on } \\
\text { system impacts } \\
\text { and performance }\end{array}$ & 1,2 & 3 & & & & & & & 3 & & & & \\
\hline $\begin{array}{l}\text { Nongovernment } \\
\text { Markets } \\
\text { Identify, } \\
\text { technical } \\
\text { character- } \\
\text { istics of sys- } \\
\text { tems }\end{array}$ & $1,2,3$ & 4 & & & $\therefore$ & & 4 & & 4 & & . & . & \\
\hline $\begin{array}{l}\text { Select projects, } \\
\text { issue RFP's }\end{array}$ & $1,2,3$ & & & & & & 4 & & 4 & & & & \\
\hline
\end{tabular}


Table 4-1. $\triangle$ CTIONS AND RESPONSIBIIITIES (continued)

\begin{tabular}{|c|c|c|c|c|c|c|c|c|c|c|c|c|c|}
\hline $\begin{array}{c}\text { Program Element } \\
\text { Actions/Tactics }\end{array}$ & $\begin{array}{l}\text { DOE/Progrem } \\
\text { Office }\end{array}$ & AID & DDC & DOD & EXIM & FTC & ISTC & JUSTICE & NASA & SBA & STATE & TREASURY & OPIC \\
\hline $\begin{array}{l}\text { Install, assess, } \\
\text { and report on } \\
\text { sy'stem impacts } \\
\text { and perfor manee }\end{array}$ & $1,2,3$ & & & & & & 4 & & 4 & & & & \\
\hline $\begin{array}{l}\text { Systems Develop- } \\
\text { ment }\end{array}$ & 1,2 & 4 & 4 & & & & 4 & & 3 & & & & \\
\hline 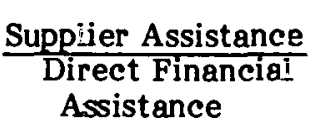 & $1,2,3$ & & 4 & & i. & & & & . & & & & \\
\hline $\begin{array}{l}\text { Marketing } \\
\text { Grants }\end{array}$ & $1,2,3$ & & 4 & & & & & & . & & & & \\
\hline $\begin{array}{l}\text { Trade Promotica } \\
\text { Activities }\end{array}$ & 1,2 & & $\varepsilon, 3$ & & & & & & & & & & \\
\hline $\begin{array}{l}\text { Review Regula- } \\
\text { tions and Tax } \\
\text { Statutes }\end{array}$ & 1,$2 ; 3$ & & 4 & & & 5 & & 5 & & & 4 & 5 & 5 \\
\hline $\begin{array}{l}\text { Financial } \\
\text { and Regul- } \\
\text { atory Out- } \\
\text { reach }\end{array}$ & $1,2,3$ & & 4 & & 4 & 5 & & 5 & & , & & 4 & 4 \\
\hline $\begin{array}{l}\text { Market } \\
\text { Assessment }\end{array}$ & 1,2 & & 3 & & & & & & & & & & \\
\hline $\begin{array}{l}\frac{\text { Purchaser }}{\text { Assistance }} \\
\text { Prepare and } \\
\text { Distribute } \\
\text { Multimedia } \\
\text { FV Material }\end{array}$ & $1,2,3$ & 4 & 4 & 2 & 4 & & 4 & . & 4 & 4 & 4 & & \\
\hline
\end{tabular}


Table 4-1. ACTIONS AND RESPONSIBMITHEs (concluded)

\begin{tabular}{|c|c|c|c|c|c|c|c|c|c|c|c|c|c|}
\hline $\begin{array}{c}\text { Program Element; } \\
\text { Actions/Tactics }\end{array}$ & $\begin{array}{c}\text { DOE/Program } \\
\text { Office }\end{array}$ & AID & DOC & DOD & EXIM & FTC & ISTC & JUSTICE & NASA & SBA & STATE & TREASURY & OPIC \\
\hline $\begin{array}{l}\text { Foreign } \\
\text { Education } \\
\text { Training }\end{array}$ & $1,2,3$ & 4 & 4 & & & 4 & & & 4 & & 4 & . & · \\
\hline $\begin{array}{l}\text { Foreign } \\
\text { Visitor } \\
\text { Training }\end{array}$ & $1,2,3$ & 4 & 4 & & & 4 & & & 4 & & 4 & & \\
\hline$\frac{\text { Information }}{\text { Clearingtiouse }}$ & $1,2,3$ & 4 & 4 & 2 & 4 & 5 & 4 & 5 & 4 & 4 & 4 & 4 & 4 \\
\hline $\begin{array}{l}\frac{\frac{\text { Program }}{\text { Management }}}{\text { Plan Execution }} \\
\text { and Assessment }\end{array}$ & $1,2,3$ & 4 & & & . & & & & 4 & & & & \\
\hline $\begin{array}{l}\text { Budgetary Respon- } \\
\text { sibility }\end{array}$ & $1,2,3$ & 4 & 4 & & & . & & . & 4 & & & & . \\
\hline $\begin{array}{l}\text { Reporting and } \\
\text { Review }\end{array}$ & $1,2,3$ & 4 & 4 & 2 & 4 & 5 & 4 & 5 & 4 & & 4 & 4 & 4 \\
\hline Liaison & $1,2,3$ & 4 & 4 & 2 & 4 & 5 & 4 & 5 & 4 & & 4 & 4 & 4 \\
\hline
\end{tabular}


SERI: 


\section{SECTION 5.0}

\section{PROPOSED BUDGET}

Table 5-1 summarizes the recommended budget for the international photovoltaic program. The program is estimated to total $\$ 135$ million from FY80-88. This amount includes both international photovoltaics projects planned prior to the preparation of this plan and new activities. Sec. 5.1 through Sec. 5.6 describe in detail the budgets for each program element, and program management. Sec. 5.7 presents a minimum budget option that could be adopted in the event that available funds are not sufficient to support the recommended budget, or a less aggressive program is determined to be more appropriate.

\subsection{RECOMMENDED BUDGET FOR PROGRAM ELEMENT 1: MARKET DEMON- STRATIONS}

Market demonstrations account for the majority (over 70\%) of the international photovoltaic program funds, for several reasons. Market demonstrations require the purchase of photovoltaic systems. Hardware projects are more costly than information and assistance programs. Market demonstrations also are a major source of information and experience useful in all of the other program elements and tactics. Only through actual experience with photovoltaic systems can users learn their real value and can suppliers make improvements. Further, market demonstrations have a direct impact on the U.S. photovoltaic industry by providing experience with photovoltaic systems and direct contact with potential international customers.

Table 5-2 shows the breakdown of the budget for market demonstrations by the four tactics in this program element. The commercial market tactic is the largest tactic. This is consistent with the finding that the most promising international market opportunities for photovoltaics appear to be in commercial markets in industrialized countries and developing countries with internal financing or access to commercial financing. Two cycles of commercial market demonstrations are included in the recommended budget.

The development market tactic is the next largest tactic. Approximately one-third of the world's development efforts are financed by international financial institutions and aid-giving countries. This market has particular importance for photovoltaics because of the upplicabllity of photovoltaic systems in energy and agricultural projects which are commonly initiated in these development efforts. The development market tactic is also important because it directly tests the applicability of photovoltaics in projects that attempt to further the economic and social advancement of developing countries. The nongovernment organization demonstration tactic is another approach to serving the needs of developing countries.

The bilateral agreements tactic is also a large component of the market demonstration program. Several large commitments to bilateral projects (e.g., the U.S.-Saudi Arabia project) have already been made. Future bilateral programs are a stated intention of U.S. policy and the Photovoltaic RD\&D Act. The budget in Table 5-2 should provide for these agreements. It is included in the demonstration program element because bilateral projects in photovoltaics are believed to be most effective in furthering photovoltaics when they are oriented toward applications and demonstration, rather than joint research and development efforts, or information exchange programs. 
Table 5-1. SUMMARY OF RECOMMENDED BUDGET

(\$Million)

\begin{tabular}{|c|c|c|c|c|c|c|c|c|c|}
\hline Program Element & FY80 & FY81 & FY82 & FY83 & FY84 & FY85 & FY86 & FY87-88 & Total \\
\hline Market Demonstrations ${ }^{\mathrm{a}}$ & 11.0 & .13 .3 & 21.3 & 26.0 & 15.3 & 5.3 & 4.8 & 2.8 & 99.8 \\
\hline Systems Development ${ }^{b}$ & 2.0 & 2.0 & - & - & - & - & - & - & 4.0 \\
\hline Supplier Assistance & .3 & $\$ .15$ & 2.0 & 2.0 & 1.0 & .05 & .05 & .1 & 7.65 \\
\hline Purchaser Assistance & .2 & -.25 & 2.7 & 2.4 & 2.3 & .1 & - & - & 8.95 \\
\hline Information Clearinghouse & .2 & .6 & 1.0 & 1.0 & 1.0 & 6 & .5 & .1 & 5.0 \\
\hline Management & .2 & $\vdots .2$ & 2.7 & 2.6 & 1.5 & .6 & .5 & .3 & 9.6 \\
\hline TOTAL & 13.9 & 20.5 & 29.7 & 34.0 & 21.1 & 6.65 & 5.85 & 3.3 & 135.0 \\
\hline
\end{tabular}

${ }^{\mathrm{a}}$ In FY80, incl $\lrcorner d e s \$ 6.5$ million for D.JE support of already planned Saidi Scler Village Project; $\$ 1$ million for DOE support of system experiments managed by NASA-Lewis; and $\$ 2$ million for AID projects managed by NASA-Lewis. In FY81, includes $\$ 1.8$ million zor DOE support of Saudi So-ar Village Project; $\$ 1$ million for DOE support of system experiments managed by NASA-Lewis; and $\$ 2.5$ million for AID projects managed by NASA-Lewis. Ir FY82, includes $\$ .85$ m:llion for DOE support of Saudi Solap V:llage Project and $\$ 2$ million of AID funds for AID programs managed oy NASA-Lewis. In FY83, includes $\$ .45$ million in DOE support for Saudi project and $\$ 2$ million for AID prcgram managed by NASA-Lewis.

${ }^{b}$ Funding for systems development follc.ws already planned DOE support for systems development work at NASA-Lewis Research Center. 
Table 5-2. MARKET DEMONSTRATION PROGRAM ELEMENT RECOMMENDED BUDGET

(\$Million)

\begin{tabular}{|c|c|c|c|c|c|c|c|c|c|}
\hline Tactic & FY80 & FY81 & FY82 & FY83 & FY84 & FY85 & FY86 & FY87-88 & Total \\
\hline Commercial Market & 1.5 & 6.5 & 13.3 & 18.7 & 10 & --- & --- & --- & 50 \\
\hline 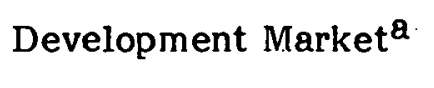 & 3.0 & 3.5 & 5.5 & 6.3 & 4.3 & 4.3 & 3.8 & .8 & 31.5 \\
\hline $\begin{array}{l}\text { Nóngovernment } \\
\text { Organizations }\end{array}$ & -- & 1.5 & 1.5 & -- & $-\infty$ & -- & --- & -- & 3 \\
\hline Bilateral Agreements ${ }^{b}$ & 6.5 & 1.8 & 1 & 1 & 1 & 1 & 1 & 2 & 15.3 \\
\hline TOTAL & 11.0 & 13.3 & 21.3 & 26 & 15.3 & 5.3 & .4 .8 & 2.8 & 99.8 \\
\hline
\end{tabular}

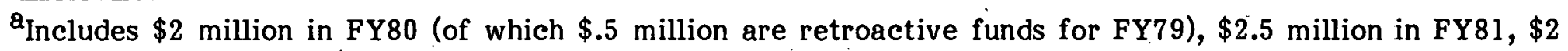
million in FY82, and $\$ 2$ million in FY83 for AID photovoltaic projects to be managed by NASA-Lewis Research Center. See AID/NASA agreement (NASA-Lewis, March 1979). Also includes $\$ 1$ million in FY80 and $\$ 1$ million in FY81 for DOE support of system experiments managed by NASA-Lewis.

b Includes $\$ 6.5$ million in FY80, $\$ 1.8$ million in FY81, $\$ .85$ million in FY82, and $\$ .45$ million in FY83 for DOE support of Saudi Solar Village Project. 
The budgets shown in Table 5-2 include already programmed projects to demonstrate international applications of photovoltaics. The ongoing AID photovoltaics project, which will be managed by NASA-Lewis Research Center, is currently budgeted at $\$ 8.5$ million from FY80-83 (NASA-Lewis, March 1979). DOE has made an additional commitment of $\$ 2$ million to NASA-Lewis for system applications projects during FY80 and FY81. The additional funds allocated to the development market tactic will expand this existing AID project and broaden its impact. Funds allocated for the bilateral agreements tactic include $\$ 9.7$ million for the U.S.-Saudi Arabia photovoltaics projects. This is an unusually large bilateral agreement. At its conclusion, funds in this tactic are expected to be sufficient to cover future, more modest agreements.

In FY80, $\$ 1.5$ million in additional funding is required for international activities to carry out the recommended market demonstration programs. In FY81, additional funding requirements are $\$ 8$ million for the market demonstration program element. Both FY80 and FY81 funds could be made available through several means.

Although not contained in Table 5-2, it should be noted that the Federal Photovoltaic Utilization Program in FY80 is scheduled to be used to build systems relevant to international markets. These systems will be built on federal facilities and will include water pumping and health care-related projects in cooperation with the Bureau of Indian Affairs, as well as other federal agencies. A recent study has shown that these and other federal applications could serve as good prototypes for international markets (Science Applications Inc. 1979).

Figure 5-1 shows the approximate breakdown of demonstration program funds by type of project. Development market demonstrations and nongovernment organization demonstrations are primarily market tests. The AID/NASA projects, however, which occur early in the development market tactic, are engineering field tests. Commercial market demonstrations include engineering and market tests and design marketing grants. Demonstrations built under bilateral agreements are engineering field tests. Other project types include special assessment studies and training efforts in support of the development market tactic.

\subsection{RECOMMENDED BUDGET FOR PROGRAM ELEMENT 2: SYSTEMS DEVELOP- MENT}

As shown in Table $5-1$, the systems development program element is proposed at $\$ 2$ million in FY80 and $\$ 2$ million in FY81, for a total of $\$ 4$ million over the duration of the international photovoltaics program. This $\$ 4$ million is to be used by DOE for systems development work by NASA-Lewis Research Center as part of their "Remote Stand Alone-Program", an element of the current domestic photovoltaics program (NASALewis, July 1979).

No new funding has been recommended for systems development work for several reasons. Photovoltaic systems for international markets use primarily off-the-shelf components in which no further development work is needed. Most system development requirements are' design improvements which will be supported through the engineering and market tests in the market demonstration program element. The greatest needs for more extensive product improvements are related to the load devices powered by photovoltaics, for example, pumps and refrigerators. More efficient load devices would improve photovoltaic system economics. Development of these load devices, however, is beyond the scope of this program. Several companies have already committed their own 


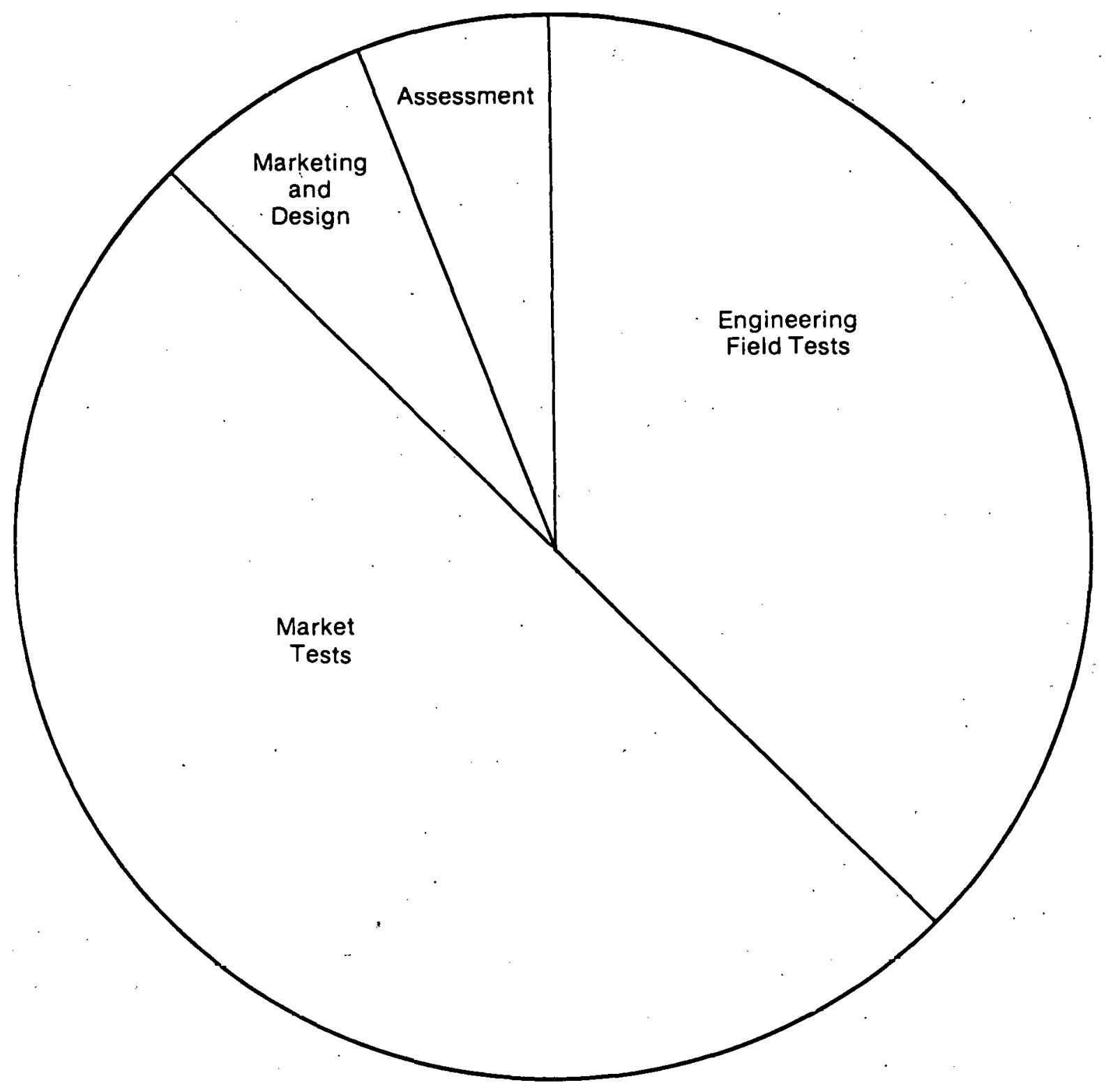

Figure 5-1. Market Demonstrations Program Element Budget by Type of Project 
resources to making these developments thus, federal support may be inappropriate. Development work on balance-of-system components such as batteries, photovoltaic module support structures, and power conditioning is currently being supported by the domestic photovoltaic program and other DOE programs. These components are similar no matter what the specific system or application, making additional projects for international photovoltaic systems unnecessary.

The $\$ 4$ million for system development in the international photovoltaic program will address a few selected system problems which will not be adequately resolved in the design efforts in the market demonstration program element. Special control problems for selected international applications, for example, could be addressed.

\subsection{RECOMMENDED BUDGET FOR PROGRAM ELEMENT 3: SUPPLIER ASSISTANCE}

Table 5-3 presents the recommended budget for the supplier assistance program ele ment. None of the tactics in this program are particularly costly. Yet they all could improve the competitive position of U.S. photovoltaic companies in international markets.

The budget for promotional assistance will support the design and construction of an industry exhibit for use at international trade fairs and other exhibits. The exhibit could be entered and staffed at between more than 15 shows per year under this program.

In the market assessment tactic, an assessment of U.S. industry capabilities and international competition will be made in FY80. Previous studies, including the assessment of international competition made in support of this plan (Appendix D), will make this assessment a modest effort. In subsequent years, the Department of Commerce could keep abreast of U.S. and for eign photovoltaic developments. The budget allows for one full-time DOC staff person to follow photovoltaic export developments, and to interact with and advise U.S. companies in photovoltaics on these developments. This staff person will also use the many sources of market information routinely gathered by DOC to identify market opportunities for photovoltaics.

Six country-specific market studies will be funded in FY81, 82 and 83 . Those studies are estimated to cost approximately $\$ 160 \mathrm{~K}$ each. The full time DOC photovoltaic staff person will be responsible for disseminating the results of the market studies through traditional DOC channels. The information clearinghouse budget will support direct dissemination to the photovoltaic industry.

Like the previous tactics, the financial and regulatory outreach tactic has minimal funding requirements. For less than \$1 million, U.S. companies will become well informed concerning how existing and future federal programs can help them market photovoltaic systems. Given the amount of resources committed to other strategies, it is essential that companies become familiar with the availability of U.S. programs and their potential benefits.

The review of export regulations and tax statutes will require a study of existing regulations and tax statutes as they affect photovoltaic exports. This study is estimated to cost $\$ 200,000$. As result of this study, a decision on early actions or modifications in existing policies could be made. This tactic offers a very low-cost approach to identifying any problems that limit current exports and opportunities for encouraging exports in the future. 
Table 5-3. SUPPLIER ASSISTANCE PROGRAM RLEMENT RECOMMENDED BUDGET

(\$Million)

\begin{tabular}{lccccccccc}
\hline TACTIC & FY80 & FY81 & FY82 & FY83 & FY84 & FY85 & FY86 & FY87-88 & TOTAL \\
\hline Promotional Assistance & .2 & .6 & .8 & .8 & .8 & - & - & - & 3.2 \\
Market Assessment & .05 & 1.05 & 1.05 & 1.05 & .05 & .05 & .05 & .1 & 3.45 \\
$\begin{array}{l}\text { Financial/Regulatory } \\
\text { Outreach }\end{array}$ & .05 & .3 & .15 & .15 & .15 & - & - & - & .8 \\
$\begin{array}{l}\text { Review of Export } \\
\quad \text { Regulatiors/Statutes }\end{array}$ & - & .2 & - & - & - & - & - & - & .2 \\
TOTAL & -.3 & $\frac{2.15}{2.00}$ & $\frac{2.00}{1.00}$ & $\frac{.05}{.05}$ & $\frac{.1}{7.65}$ \\
\hline
\end{tabular}


In summary, this program element represents a modest cost for a program which could directly promote U.S. photovoltaic products, increase the visibility of the U.S. industry in international markets, and help U.S. companies take advantage of market opportunities created through other program elements and tactics of the plan. No existing funding commitments to these programs exist. Thus, the total budget shown in Table 5-3 represents additional funding requirements. Given their low cost and potential effectiveness, these tactics should be an important element of the international photovoltaic program.

\subsection{RECOMMENDED BUDGET FOR PROGRAM ELEMENT 4: PURCHASER ASSIST- ANCE}

Table 5-4 shows the proposed budgets for each tactic in the purchaser assistance program element. Like the supplier assistance program, this program is low in cost but has the potential for greatly improving knowledge of the capabilities of photovoltaic systems on the part of potential purchasers and increasing the likelihood that these purchasers will choose photovoltaics.

The foreign visitor program will involve potential buyer decision makers froul furtign governments and industry. These visitors will attend a shorter, less technical course than in the education and training tactic. Visits to U.S. demonstration projects and photovoltaic suppliers will also be scheduled. At an etimated cost per visitor of $\$ 2,500$, this program will support about 20 visitors in FY80, 200 in FY81 and 600 for the remaining years. More visitors may be accommodated because of cost sharing and visits supported totally by foreign sources.

The foreign education and training tactic will support the travel of foreign engineers, distributors and installers to the U.S., and their attendance at a technical course on photovoltaic systems. They will also visit selected U.S. photovoltaic demonstrations and U.S. suppliers. Visitors will be expected to cost-share their participation in this program. At an average cost to the U.S. government of $\$ 5,000$ per visitor, this program provides for about 20 visitors in FY80, 60 in FY81 and 120 in the remaining years of the program,

The final tactic relies on already established information networks within U.S. embassies, AID missions, and nongovernment organizations. Funds budgeted for this tactic support preparation of special information packages to be used and disseminated by these groups. Information made available through other program elements, particularly the market demonstrations, will be used to prepare materials in FY82.

No funds have been programmed for these tactics prior to this plan. Therefore, additional funding will.be required to support this program element.

\subsection{RECOMMENDED BUDGET FOR PROGRAM ELEMENT 5: INFORMATION CLEARINGHOUSE}

Table 5-1 shows that through FY88, the information clearinghouse budget is estimated to total $\$ 5$ million. The primary function of the international photovoltaic program is to generate and disseminate information to potential users of photovoltaics and U.S. suppliers. The information clearinghouse will be the focal point of information and dissemination activities. 
Table 5-4. PURCHASER ASSISTANCE PROGRAM ELEMENT RECOMMENDED BUDGET

(\$Million)

\begin{tabular}{|c|c|c|c|c|c|c|c|c|c|}
\hline Tactic & FY80 & FY81 & FY82 & FY83 & FY84 & FY85 & FY86 & FY87-88 & Total \\
\hline Foreign Visitors & .05 & .45 & 1.6 & 1.6 & 1.6 & - & $\longrightarrow$ & - & 5.3 \\
\hline Education and Training & .1 & .3 & .6 & .6 & .6 & - & - & - & 2.2 \\
\hline U.S. Agency/NGO Awareness & .05 & .5 & .5 & .2 & .1 & .1 & - & - & 1.45 \\
\hline TOTAL & .2 & 1.25 & 2.7 & 2.4 & 2.3 & .1 & - & - & 8.95 \\
\hline
\end{tabular}


Three types of projects will account for the information clearinghouse funds. These are information collection and analysis projects, mass media information dissemination projects, and special audience dissemination projects. The information collection and analysis projects are estimated to require about half of the information clearinghouse funds, and the other half will go for information dissemination.

\subsection{RECOMMENDED BUDGET FOR MANAGEMENT}

Management costs have been estimated at approximately $10 \%$ of newly initiated activities. Management costs have not been assessed for ongoing projects because of the limited need for planning, coordinating, and monitoring these programs. Management of ongoing programs such as the U.S.-Saudi Arabia bilateral agreement and NASA-Lewis systems development projects and the joint project with AID will be confined to liaison.

Monitoring, assessment, and selection of market demonstration projects will be the largest requirement of the management budget. Evaluation criteria and procurement procedures will need to be developed. Project accounting, periodic reporting, and annual revisions in the program plan are also included in the management budget. Liaison with participating U.S. agencies, international organizations, and the photovoltaic industry will be maintained by a staff person in the program management of fice.

\subsection{MINIMUM BUDGET OPTION}

Table 5-5 shows a minimum budget option that could be adopted if funds sufficient for the recommended program are not available or if DOE decides that a less aggressive and less costly program would be appropriate. The minimum budget option cannot be expected to have the same impact on international markets for photovoltaics and on the U.S. photovoltaic industry as the recommended budget option, because direct and indirect impacts of the program would be reduced significantly. However, the minimum budget option would add to the information available to users and suppliers of photovoltaic applications. Nevertheless, it will do so less aggressively than the recommended option.

The minimum budget program shows reductions primarily in the market demonstration program element. Only one cycle of the commercial market program would be pursued. This cycle would still allow the installation of more than 375 systems in commercial markets. The commercial market tactic has been maintained at a substantial level in the minimum budget option because it is believed to be a key element of the program. Without some effort in this market, the program would have little positive impact on international market development or on U.S. industry.

Development market demonstrations are limited to the existing AID/NASA project, existing DOE-supported application projects managed by NASA-Lewis, and three cycles of development demonstrations for FY82, FY83, and FY84 (each funded at \$1 million). Assuming an average system size of $5 \mathrm{~kW}$, a total of approximately 50 systems. could be installed in additional market demonstrations.

A small, nongovernment program has been retained in the minimum option to take advantage of the strong information network that concerned organizations have throughout the world. Bilateral agreement demonstrations have been limited to funding only existing agreements. Given the high cost of these projects, and the difficulty of initiating them and matching them to market opportunities, these reductions seem justified. 
Table 5-5. MINIMUM BUDGET OPTION

(\$Million)

\begin{tabular}{|c|c|c|c|c|c|c|c|c|c|}
\hline $\begin{array}{l}\text { Program Element/ } \\
\text { Tactic }\end{array}$ & FY80 & FY81 & FY82 & FY83 & FY84 & FY85 & FY86 & FY87-88 & Total \\
\hline \multicolumn{10}{|l|}{ Market Demonstrations ${ }^{\mathrm{a}}$} \\
\hline Commercial market & --- & 4 & 3 & 10 & 8 & -- & -- & --- & 25. \\
\hline Development market & 3. & 3.5 & 3 & 3 & 1 & .2 & .2 & .2 & 14.1 \\
\hline Nongovernment & --- & 5 & 5 & --- & -- & --- & --- & -- & \\
\hline Bilateral agreements & 6.5 & 1.0 & $1^{.0}$ & 1 & - & - & - & -- & 10.3 \\
\hline Subtotal & 9.5 & 5.3 & 7.5 & 14 & 9 & .2 & .2 & .2 & 50.4 \\
\hline Systems Development ${ }^{b}$ & 2.5 & 2.5 & --- & --- & --- & -- & --- & --- & 5 \\
\hline \multicolumn{10}{|l|}{ Supplier Assistance } \\
\hline Promotional assistance & .2 & .1 & .1 & .1 & .1 & --- & --- & --- & .6 \\
\hline Market assessment & --- & .5 & .5 & .5 & .05 & .05 & .05 & .1 & 1.75 \\
\hline Financial/regulatory & & & & & & & & & \\
\hline outreach & .05 & .15 & --- & -- & --- & --- & $-\infty$ & --- & .2 \\
\hline Review export regu- & & & & & & & & & \\
\hline lations/statutes & .2 & --- & --- & $z--$ & --- & -- & $\underline{--}$ & $\underline{---}$ & .2 \\
\hline Subtotal & .45 & .75 & .6 & .6 & .15 & .05 & .05 & .1 & 2.75 \\
\hline \multicolumn{10}{|l|}{ Purchaser Assistance } \\
\hline Foreign visitors & .05 & .3 & .5 & .5 & .5 & -- & -- & -- & 1.85 \\
\hline Education and training & .1 & .3 & .3 & .3 & .3 & --- & --- & --- & 1.3 \\
\hline \multicolumn{10}{|l|}{ U.S. agency/NGO } \\
\hline awareness & .1 & .2 & .2 & .2 & .2 & .1 & $\underline{---}$ & --- & 1 \\
\hline Subtotal & .25 & .8 & 1 & 1 & .1 & .1 & --- & --- & 4.15 \\
\hline Information clearinghouse & .2 & .6 & 1 & 1 & 1 & .6 & .5 & .1 & 5 \\
\hline Management & .1 & .7 & .7 & 1.4 & 1.1 & .1 & .05 & .1 & 4.25 \\
\hline Total & 13.0 & 15.15 & 10.8 & 18.0 & 12.25 & 1.05 & .8 & .5 & 71.55 \\
\hline
\end{tabular}

${ }^{2}$ In FY80, includes $\$ 6.5$ million for DOE support of already planned Saudi Solar Village Project; $\$ 1$ million for DOE support of system experiments managed by NASA-Lewis; and $\$ 2$ million for AID projects managed by NASA-Lewis. In FY81, includes $\$ 1.8$ million for DOE support of Saudi Solar Village Project; $\$ 1$ million for DOE support of system experiments managed by NASA-Lewis; and $\$ 2.5$ million for AID projects managed by NASA-Lewis. In FY82, includes $\$ .85$ million for DOE support of Saudi Solar Village Project and $\$ 2$ million of AID funds for AID programs managed by NASA-Lewis. In FY83, includes $\$ .45$ million in DOE support for Saudi project and $\$ 2$ millior for AID program managed by NASA-Lewis.

${ }^{b}$ Funding for systems development follows already planned DOE support for systems development work at NASA-Lewis Research Center. 
The supplier assistance program element has also been reduced substantially. A modestlevel industrywide international exhibit would be supported, in the promotional assistance tactic. Publicly available market studies would be conducted in only nine countries (compared with 18 in the recommended budget) and few direct efforts to inform industry about existing government programs and regulations would be made.

In the purchaser assistance program element, the number of visitors in the education and training and foreign visitor tactics have been reduced by more than half. A scaled-down government agency and nongovernment organization awareness tactic has been included.

The information clearinghouse budget has not been changed in the minimum option and remains at $\$ 5$ million. Information collection and dissemination is so crucial to the success of any international program for photovoltaics that an aggressive effort in this area should be maintained. While less information would be generated in program elements and tactics in the minimum budget option, available information should be used as much as possible.

The management budget has been reduced to reflect other budget reductions. No changes in the systems development program element have been made, since this program is already limited to ongoing projects. 


\section{SECTION 6.0}

\section{EXPECTED IMPACTS AND BENEFTS OP THE INTERNATIONAL PHOTOVOLTAICS PROGRAM PLAN}

The expenditure of government resources on the activities outlined in this plan will result in both primary and secondary benefits. The primary benefits include the acceleration of photovoltaic sales and impacts on prices through increased sales. Secondary benefits are the immediate impacts of the program; for example, the approximately 100 engineering field tests and approximately $\mathbf{7 5 0}$ market tests called for the commercial market demonstration tactic in Program Element 1. Other sets of benefits include impacts on the product development process and those listed in the legislation, for example, encouragement of small business.

This discussion of impacts and benefits assumes that the recommended budget option is adopted, because both primary and secondary benefits resulting from the minimum budget option will be lower than those resulting from the recommended option. Nevertheless, the minimum budget option is likely to still have a significant impact on international market development.

\subsection{ESTIMATES OF THE PLAN'S PRIMARY AND SECONDARY BENEFITS}

The primary benefits of the plan are its impacts on sales and prices. These benefits result from the leverage of the plan's activities on the behavior of producers and endusers. These benefits are estimated by increased photovoltaic industry sales volumes, changes in photovoltaic system prices, and the increased $\mathrm{MW}$ of photovoltaic power to serve international needs. (See Sec. 6.1.1). The secondary benefits associated with the implementation of the plan are discussed in Sec. 6.1.2.

\subsubsection{Estimates of the Primary Benefits of the Plan}

The time and resource constraints of preparing the plan did not allow an independent analysis of the expected benefits of the plan. The next best alternative is to adopt other benefit analyses for use in analyzing the plan.

The benefits of the plan have to be estimated by the change in purchaser and supplier actions resulting from the plan. It is clear that international photovoltaic markets will develop and expand without government involvement. The plan's impacts have to be considered in light of how they accelerate the development of these markets. To estimate these impacts, one must have at least two scenarios of future international market penetration. Ideally, the first should assume no U.S. government involvement in those markets while the second assumes the plan is implemented.

Two recent photovoltaic studies include multiple estimates of market penetration that can be used to analyze the benefits of the plan. The first is the Export Potential for Photovoltaic Systems (Pacific Northwest Laboratories 1979) which attempted to forecast the worldwide demand for nonutility connected photovoltaic applications. The second is thé Photovoltaic Venture Analysis (Costello et al. 1978) which was generally more conservative in its market estimates and included estimates of both international and U.S. utility-connected markets for photovoltaics. 
The two studies differ in a wide variety of assumptions and in the details of their methodology. However, they are similar in the sources of their market information and in their approach to presenting results. Both studies admit that there is a great deal of uncertainty about the size, price, and characteristics of international markets. To incorporate this uncertainty, the studies present alternative scenarios of market penetration. The scenarios differ by their estimates of market potential ( $M W)$, the estimates of breakeven prices (the price at which photovoltaics equal the price of conventional alternatives) and the rate of adoption.

The international photovoltaic plan will have an impact on the same market parameters that determine the market scenarios in these studies. The demonstrations and information program elements (supplier assistance, purchaser assistance, and the information clearinghouse) will make purchasers more aware of the capabilities and costs of photovoltaics. This heightened awareness will increase the rate of adoption in these marke.ts. It will also increase the market potential of each market by expanding the number of individuals considering photovoltaics. Finally, it could make photovoltaics more attractive at higher prices than without the plan because purchasers are awule of relative prices and attributes of the alternatives. The degree of price differential needed to make purchasers consider photovoltaics is diminished because widespread information is substituted for the product notoriety that would be obtained from larger price advantages.

Table 6-1 presents some of the results of the Export Potential for Photovoltaic Systems. Two years were selected from the study to analyze the impacts of the plan immediately at the conclusion of its main activities (1986) and further into the future to examine its longer-range impacts (2000). The study estimated low, medium, and high Ievels of sales to international markets. The key markets (corrosion protection, water pumping, and general village power sources) are presented in the table. Assuming that the international plan's impact on the development of markets will result in larger markets, the benefits of the plan can be estimated by the differences between the low, medium and high estimates. Columns 3 and 5 in the table show those differences.

If the plan accelerates the development of international markets so that the medium rather than low market estimate becomes more probable, the indirect benefits will be approximately $39 \mathrm{MW}_{\mathrm{p}}$ additional sales in 1986 and $515 \mathrm{MW}$ in 2000 . Using the 1986 module price assumptfons of the study $\left(\$ .60 / W_{\mathrm{p}}\right.$ (Pacific Northwest Labs 1979, p. 2-12), the photovoltaic module industry revenue in 1986 would be $\$ 23$ million. The industry revenue resulting from the manufacture of power conditioning, structures, and system installation could total as much as $\$ 215$ million (assuming $\$ .80 / \mathrm{W}_{\mathrm{p}}$ for power conditioning and structures and $\$ 4.68 / \mathrm{W}_{\mathrm{p}}$ for installation) (Pacific Northwest Labs $1979, \mathrm{p} .2-12$ ). Of course, much of this revehue, especially for nonmodule components and installation, would be received by parts of the industry located overseas. In particular, it is likely that installers would be located in the purchasing nation. The manufacturer of other balance-of-system components or the company assembling the system may also be loculed in the purchasing country. In these cases, the increased revenues resulting from the plan would be received in the country making the purchase. In fact, using the price estimate of this study, the overwhelming majority of revenues would probably remain in the country purchasing the systems.

If the plan's impact was to increase market development from the medium to high forecast in the export potential study, significantly larger benefits would result. As the table indicates; 1986 worldwide sales could increase by $77 \mathrm{MW}_{\mathrm{p}}$ and year 2000 sales by $752 \mathrm{MW}_{\mathrm{P}}$. Using the 1986 module and system price forecasts mentioned above, photovoltaic module revenues would be enhanced by $\$ 46$ million in 1986 . Nonmodule revenues 
Table 6-1. PRIMARY BENBFTS OP THE INTERNATIONAL PHOTOVOLTAC PROGRAM PLAN: ESTMATED PROM THE EXPORT POTENTLAL FOR PHOTOVOLTAIC SYSTEMS

( $M W_{p}$ Annual Sales)

\begin{tabular}{|c|c|c|c|c|c|c|c|c|c|c|}
\hline \multirow[t]{2}{*}{$\begin{array}{l}\text { Market/ } \\
\text { Applications }\end{array}$} & \multicolumn{2}{|c|}{ (2) } & \multicolumn{2}{|c|}{$\begin{array}{l}\text { (3) } \\
\text { Benefits of Plan; } \\
\text { Change from } \\
\text { Low to Medium } \\
\text { Market Scenarios }\end{array}$} & \multicolumn{2}{|c|}{$\begin{array}{l}\text { Export Potential Study; } \\
\text { Medium Estimate }\end{array}$} & \multicolumn{2}{|c|}{$\begin{array}{l}\quad(5) \\
\text { Benefits of Plan; } \\
\text { Change From } \\
\text { Medium to High } \\
\text { Market Scenarios }\end{array}$} & \multicolumn{2}{|c|}{$\begin{array}{l}\text { Export Potential Study; } \\
\text { High Estimate }\end{array}$} \\
\hline & 1386 & $\underline{2000}$ & $\underline{1986}$ & 2000 & $\underline{1986}$ & $\underline{2000}$ & 1986 & $\underline{2000}$ & 1986 & $\underline{\mathbf{3 0 0 0}}$ \\
\hline $\begin{array}{l}\text { Corrosion } \\
\text { Protection }\end{array}$ & 3.2 & 11.0 & 1.3 & 6.0 & 4.5 & 17.0 & 0.4 & 8.0 & 4.9 & 25.0 \\
\hline $\begin{array}{l}\text { General Village } \\
\text { Power Sources }\end{array}$ & 0.9 & 10.0 & 9.1 & 90.0 & 10.0 & 100.0 & 14.0 & 300.0 & 24.0 & 430.0 \\
\hline $\begin{array}{l}\text { Total Inter- } \\
\text { national } \\
\text { Market (Includin } \\
\text { Communication; } \\
\text { Marking and Wa } \\
\text { Devices, and Co } \\
\text { Products) }\end{array}$ & $\begin{array}{l}14.0 \\
\text { ig } \\
\text { rning } \\
\text { nnsurner }\end{array}$ & 106.0 & & & 53.0 & 621.0 & & & 130.0 & $1,373.0$ \\
\hline $\begin{array}{l}\text { Total Annual } M W_{R} \\
\text { Impect of the } P 1\end{array}$ & $\operatorname{lan}$ & & 39.0 & 515.0 & & & 77.0 & 752.0 & & \\
\hline
\end{tabular}

QPacific Northwest Laboratories 1979.

bibid., p. 3.7.

CIbld., p. 3.28 .

doid., p. 3.35. 
would increase by $\$ 422$ million in the same year. The large MW increment in year 2000 can be interpreted as an indication of how accelerating early international markets can impact sales to those markets over many future years.

The Photovoltaic Venture Analysis dealt with the current uncertainty about international markets by constructing four market scenarios. As in the export potential study, these scenarios differed by market size and break-even price. The scenarios allow the same analysis of benefits to be derived as in the export potential study. Table 6-2 presents the market scenarios and estimates of the benefits of moving from one scenario to the next larger one.

The table includes four key international markets and divides the U.S. utility or grid-connected market into two segments. Inclusion of these later U.S. markets allows a first approximation of the plan's impact on displacing conventional energy sources in the United States. As mentioned in Sec. 1.0, international markets can act as a bridge to these U.O. markets. The dcvolopmont of U.S. markets is ancelerater hy the silcressful achievement of the international plan's ubjective.

If the intermediate (primarily international) markets are relatively small (Col. 2 of Table $6-2)$, the plan might increase these markets to the size of the moderate market scenario (Col. 4). Assuming this impact on market size and breakeven prices, the plan would result in 6.3 $\mathrm{MW}_{\mathrm{p}}$ of additional sales in 1986 and $28.5 \mathrm{MW}_{\mathrm{p}}$ additional sales in 1996. The plan would have an accelerating effect on the rate of adoption of photovoltaics in U.S. grid-connected markets as indicated by about $73 \mathrm{MW}_{\mathrm{p}}$ additional sales to these markets in 1996. The small market scenario was given a low probability of occurance in the venture analysis. However, even in this situation the plan could have a sizeable impact on U.S. market developments in the 1990s.

The most likely market sizes identified in the Photovoltaic Venture Analysis were those in the moderate market scenario. If one assumes that the plan increases the size of these markets to those indicated by the large market scenario, the incremental benefits are larger. As shown in Col. 5 of the table, additional international sales could reach $28.2 \mathrm{MW}_{\mathrm{p}} / \mathrm{yr}$ and $102.7 \mathrm{MW}_{\mathrm{p}} / \mathrm{yr}$ in 1986 and 1996 , respectively. The impuct of the plan on U.S. markets is also larger, adding about $227 \mathrm{MW}_{\mathrm{p}}$ to annual sales in 1996.

The last three columns of the table display the large and very large market scenarios of the venture analysis. Col. 7 indicates that the incremental sales to international markets would be $138.9 \mathrm{MW}_{\mathrm{p}} / \mathrm{yr}$ in 1986 and $285.5 \mathrm{MW}_{\mathrm{p}} / \mathrm{yr}$ in 1996 due to the plan. Sales to U.S. grid markets would be accelerated at approximately the same rate as those under llie change from the moderate to large market scenarios.

The increased sales resulting from the plan and any associated reductions in photovoltaic prices will result in other, less quantifiable benefits. The first is to maintain, stabilize, and foster the expansion of the photovoltaic industry, both in the United States and abroad. Direct expenditures for systems in the plan (discussed in Sec. 6.1.2) and the leverage on non-subsidized sales both contribute to this benefit. The second non-quantitative benefit is the plan's contribution to the economic, political, and social advancement of developing countries. Photovoltaics can serve to counter the inhibiting effect of increasing oil prices on the pace of development in these nations. The third benefit is to reduce the rate of growth in the worldwide demand for oil. Another benefit of the plan is that it will help improve the United States balance of trade. These benefits are discussed further in Sec. 1.0. 
Table 6-2. PRIMARY BenEFTs OP THE INTERNATIONAL PHOTOVOLTAIC PROGRAM PLAN: BSTTMATED FROM THB PHOTOVOLTAIC VENTURE ANALYSS (MW p Annual Sales)

\begin{tabular}{|c|c|c|c|c|c|c|c|c|c|c|c|c|c|c|}
\hline \multirow[t]{2}{*}{$\begin{array}{c}\text { Market/ } \\
\text { Applications }\end{array}$} & \multicolumn{2}{|c|}{$\begin{array}{l}\text { (2) } \\
\text { Venture Analysis } \\
\text { Small Inter- } \\
\text { mediate Market } \\
\text { Scenario }\end{array}$} & \multicolumn{2}{|c|}{$\begin{array}{c}\text { (3) } \\
\text { Benefits of } \\
\text { Plan; Change } \\
\text { From Small to } \\
\text { Moderate Market } \\
\text { Scenarios }\end{array}$} & \multicolumn{2}{|c|}{$\begin{array}{l}\text { (4) } \\
\text { Venture Analysis } \\
\text { Moderate Inter- } \\
\text { ediate Market } \\
\text { Scenario }\end{array}$} & \multicolumn{2}{|c|}{$\begin{array}{l}\text { (5) } \\
\text { Benefits of } \\
\text { Plan; Change } \\
\text { From Moder- } \\
\text { ate to Large } \\
\text { Scenarios }\end{array}$} & \multicolumn{2}{|c|}{$\begin{array}{c}\text { (6) } \\
\text { Venture Analy- } \\
\text { sis Large } \\
\text { Intermediate } \\
\text { Market Scenarioc }\end{array}$} & \multicolumn{2}{|c|}{$\begin{array}{c}\text { (7) } \\
\text { Benefits of } \\
\text { Plan; Change } \\
\text { From Large } \\
\text { to Very Large } \\
\text { Scenarios }\end{array}$} & \multicolumn{2}{|c|}{$\begin{array}{c}(8) \\
\text { Venture Analysis } \\
\text { Very Large } \\
\text { Intermediate } \\
\text { Market Scenario }\end{array}$} \\
\hline & $\underline{1986}$ & $\underline{1996}$ & 1986 & 1996 & $\underline{1986}$ & $\underline{1996}$ & $\underline{1986}$ & $\underline{1996}$ & $\underline{1986}$ & 1996 & $\underline{1986}$ & 1996 & 1986 & 1996 \\
\hline $\begin{array}{l}\text { Non-U.S. Low } \\
\text { Lift Pumping }\end{array}$ & .4 & 13.0 & 1.0 & 16.1 & 1.4 & 29.1 & 1.3 & 28.9 & 2.7 & 58.0 & 16.1 & 68.8 & 18.8 & 126.8 \\
\hline $\begin{array}{l}\text { Non-U.S. Medium } \\
\text { Lift Pumping }\end{array}$ & .02 & 3.3 & 2.78 & 6.3 & 2.8 & 9.6 & 25.2 & 69.2 & 28.0 & 97.2 & 93.9 & 166.6 & 121.9 & 263.8 \\
\hline $\begin{array}{l}\text { Non-U.S. Deep } \\
\text { Well Cathodic } \\
\text { Protection }\end{array}$ & .1 & .2 & .6 & 1.2 & .7 & 1.4 & 0 & 0 & .7 & 1.4 & 3.5 & 6.9 & 4.2 & 8.3 \\
\hline $\begin{array}{l}\text { Non-U.S. Remote } \\
\text { General Power }\end{array}$ & o & .3 & 1.9 & 4.9 & 1.9 & 5.2 & 1.7 & 4.6 & 3.6 & 9.8 & 25.4 & 43.2 & 29.0 & 53.0 \\
\hline $\begin{array}{l}\text { U.S. Grid-Con- } \\
\text { nected: Sunbedt }\end{array}$ & .01 & 54.8 & .01 & 96.5 & .02 & 151.3 & 0 & 110.0 & $\therefore .02$ & $261.3=$ & .08 & 69.3 & .1 & 330.6 \\
\hline $\begin{array}{l}\text { U.S. Grid-Con- } \\
\text { nected: Non- } \\
\text { Sunbelt }\end{array}$ & 0 & 15.7 & 0 & 47.8 & 0 & 63.5 & 0 & 117.3 & 0 & 180.8 & .02 & 156.2 & .02 & 337.0 \\
\hline \multicolumn{3}{|c|}{$\begin{array}{l}\text { Total Annual } \mathrm{MW}_{\mathrm{p}} \text { Impact } \\
\text { of Plan: Non-U.S. } \\
\text { Markets }\end{array}$} & 6.28 & 28.5 & & & 28.2 & 102.7 & & & 138.9 & 285.5 & & \\
\hline \multicolumn{3}{|c|}{$\begin{array}{l}\text { Total Annual } M W_{P_{\text {an: }}} \\
\text { Impact of the Plan } \\
\text { U.S. Grid Markets }\end{array}$} & .01 & 144.3 & & & 0 & 227.3 & & & .1 & 225.5 & & \\
\hline \multicolumn{3}{|l|}{$\begin{array}{l}\text { Grand Total } \\
\text { Annual } M W_{p} \\
\text { Impact of the Plan }\end{array}$} & 6.29 & 172.8 & & & 28.2 & 330.0 & & & 139.0 & 511.0 & & \\
\hline
\end{tabular}

${ }^{a}$ Costello et al. 1978, p. 168.

bibid., p. 170.

cIbid., p. 165.

dbid., p. 172. 


\subsubsection{Secondary Benefits of the Plan}

The secondary benefits of the plan are those that result directly from expenditures of U.S. government funds. These benefits are certain of occuring but they do represent only intermediate outputs of the plan. Nonetheless, they are important as a baseline estimate of government purchases that the industry can expect. Table 6-3 summarizes the direct benefits of each of the plan's program elements. One secondary benefit is the large number of engineering field tests and market tests placed in the U.S. and in approximately 25-50 other nations. The first three rows of the table show the dispersions of these demonstrations across commercial, development and nongovernment organization markets. Another secondary benefit is the large number of potential purchasers receiving direct information. For example, the foreign visitor program will involve over 2,000 potential buyers and the foreign education and training program will have over 400 participants. Other secondary benefits presented in the table are the systems development results, direct aid to suppliers, and the country-specific market studies.

\subsection{IMPACTS AND BENEFITS RELATIVE TO THE PRODUCT DEVELOPMENT PROCESS}

The concept of a product development process is used by market research experts to determine the actions necessary to commercialize a product. One technique to measure the benefits of the plan is to consider how the various program elements address the steps of the product development process. If these steps are adequately addressed, it is probable that the plan will be successful in accelerating photovoltaic products through the cycle.

Before discussing the impacts of the plan on these steps, it is useful to review the concept. A recent DOE draft plan (July 1979) outlined eight steps that comprise the product development process. They are:*

1. Basic Matcrials Research

2. Market Research and Product Justification

3. Component Development and Testing

4. Prototype System Development and Testing

5. Field Testing

6. Market Testing

7. Production

8. Sales and Marketing

The process begins with identifying a concept or technology that serves a useful function (step 1). Next, the market research and product justification step (step 2) establishes specific performance and cost goals that the product must meet to compete in the marketplace.

Steps 3 and 4 in the process are the development of specific components of the product and the combination of those components into a prototype system for testing. Once a system that is operational has been built, the system is tested in realistic settings during,

*Alternative ways of dividing the product development process could be conceived. However, the steps listed here include most elements of the process. 
Table 6-3. SECONDARY BENEFITS OF INTERNATIONAL PHOTOVOLTAIC PROGRAM PLAN

Name of Program

Element Tactic
Time Frame

(Fiscal Years)
Secondary Impacts

1. MARKET DEMONSTRATIONS

Commercial

Development

Nongovernment

Organizations

Bilateral and

Multilateral

Agreements

Saudi Solar

Village Project
$81-84$

$82-86$

$80-82$

180 Market Tests (average $1 \mathrm{kWp}$ ) built in over 25 countries; . $1 \mathrm{MW}_{\mathrm{p}}$ installed

- Over 750 Market Field Tests (average $5 \mathrm{~kW}_{\mathrm{p}}$ ) built; $3.75 \mathrm{MW}_{\mathrm{p}}$ installed

- 35 companies develop international marketing plans; 30 companies build and market systems

- 30 U.S. companies affiliate with 60 foreign distributers/ installers in 50 countries

- Over 300 Market Tests (average size; $5 \mathrm{~kW}_{\mathrm{p}}$ ) built in 50 developing countries; $1.63 \mathrm{MW}_{\mathrm{p}}$ installed

- Approximately 25 U.S. companies gain market experience

$.5 \mathrm{MW}_{\mathrm{p}}$ village power system installed

Awareness of photovoltaic systems raised to high level of government and international visability 
Table 6-3. SECONDARY BENEPITS OF INTERNATIONAL PHOTOVOLTAIC PROGRAM PLAN (continued)

Name of Program

Element/Tactic

Other agree-

ments

2. SYSTEMS

DEVELOPMENT

3. SUPPLIER

ASSISTANCE

Promotional

80-83

Assistance

Market

Assessment

Financial and

Regulatory Out-

reach

Review of Export

Regulations and

Tax Statutes
Time Frame

(Fiscal Years)

Secondary Impacts

To be determined

$81-84$

$\$ 5$ million in federal $R \& D$, cost shared by industry, produces more efficient, esonomical photovoltair: components/systems
$M W_{p}$ installed dependent on new agreements

Awareness of photovoltaic systems increases as new agreements are undertaken
- U.S. industry exhibit built and shown at more than 15 trade promotional activities (e.g., trade fairs)

- 18 country-specific market studies prepared and disseminated

- ongoing advice to ŨS industry on market opportunities provided by Commerce

- Manual on availability of U.S. support for financing and compliance with export regulations

- Advice provided to U.S. industry on export assistance programs

81-82

Recommendations on special tax provisions and regulations for photovoltaic exports 
Table 6-3. SECONDARY BENEFITS OF INTERNATIONAL PHOTOVOLTAIC PROGRAM PLAN (concluded)

\begin{tabular}{|c|c|c|c|}
\hline \multicolumn{2}{|c|}{$\begin{array}{l}\text { Name of Program } \\
\text { Element/Tactic }\end{array}$} & \multirow[t]{2}{*}{$\begin{array}{c}\text { Time Frame } \\
\text { (Fiscal Years) }\end{array}$} & \multirow[t]{2}{*}{ Secondary Impacts } \\
\hline 4. & $\begin{array}{l}\text { PURCHASER } \\
\text { ASSISTANCE }\end{array}$ & & \\
\hline & $\begin{array}{l}\text { Foreign Visitor } \\
\text { Program }\end{array}$ & $81-84$ & $\begin{array}{l}\text { Over } 2000 \text { potential buyers (gov- } \\
\text { ernment and industry officials) } \\
\text { familiarized with photovoltaic } \\
\text { systems and U.S. products }\end{array}$ \\
\hline & $\begin{array}{l}\text { Foreign Educa- } \\
\text { tion and Training }\end{array}$ & $80-83$ & $\begin{array}{l}400 \text { staff engineers for potential } \\
\text { purchasers and installers instruc- } \\
\text { ted on photovoltaic system design } \\
\text { and economics and introduced to } \\
\text { U.S. products }\end{array}$ \\
\hline & $\begin{array}{l}\text { U.S. Agency. and } \\
\text { Nongovernment } \\
\text { Organization } \\
\text { Awareness }\end{array}$ & $80-85$ & $\begin{array}{l}\text { Information packets, multi- } \\
\text { media presentations on photo- } \\
\text { voltaics sent to } 65 \text { AID country } \\
\text { missions, and selected U.S. } \\
\text { Embassies }\end{array}$ \\
\hline 5. & $\begin{array}{l}\text { INFORMATION } \\
\text { CLEARINGHOUSE }\end{array}$ & $80-88$ & $\begin{array}{l}\text { Worldwide collection and distribu- } \\
\text { tion of information on photovol- } \\
\text { taic demonstrations applications, } \\
\text { systems, and markets. }\end{array}$ \\
\hline
\end{tabular}


the field testing step. Market testing (step 6) involves putting a large number of systems in the field to better understand the reactions and attitudes of potential buyers. After each of these steps have been successfully completed, commercial production begins. The final step (step 8 ) is to promote and sell the product.

The status of photovoltaic systems for international applications cannot be identified as being at a single step of the product development process. Photovoltaic systems are part of a variety of products, differing primarily by which markets they serve. Communications applications of photovoltaics, for example, are in the production and sales/marketing steps of the process. Photovoltaic systems for water pumping are in the prototype development and field testing stages. Some refrigeration systems are in the component development step.

The plan is intended to accelerate the development of all international photovoltaic applications. Therefore, it is necessary for the elements of the plan to simultaneously address most of the latter steps of the product development cycle. Figure 6-1 summarizes how the elements of the plan apply to each step of the product development process. Some interesting aspects of the table should be noted. First, none of the plan's tactics addresses basic materials research. Photovoltalc systems for international applications have progressed past this step and domestic programs are addressing these problems in relation to longer-term products. Another interesting aspect is that the commercial market demonstration tactic sequentially addresses four key steps in the product development process. The tactic is designed in stages to progressively address each of these steps and lead to additional sales in international commercial markets. It begins with market research and product justification support. This support is followed by field testing. After successful field testing funds are made available for test marketing. Sec. 3.0 contains further details on the design of this tactic.

In summary, the plan is designed to impact all the relevant steps of the product development process. The probability of success is greatly enhanced by not ignoring any of these steps. If the plan were designed to aid the industry in only a few of these steps, the result could fall far short of the primary objective of the plan.

\subsection{OTHER BENEFTS OF THE PLAN}

In fulfilling the Congressional mandate described in the Photovoltaic RD\&D Act of 1978, other benefits are achieved which were highlighted by the law. Sec. 1.1 discussed the Act's requirements for preparing the plan. The plan has also been cunstructed to serve many other of the policies and programs described in the Act. First, Sec. 10(a) of the Act requires that:

The Secretary (of Energy) shall take all possible steps to assure that full and complete information with respect to the demonstrations and other activities conducted under this Act is made available to Federal, State and local authorities, relevant segments of the economy, the scientific and technical community and the public at large, both during and after the close of the programs under this Act, with the objective of promoting and facilitating to the maximum extent feasible the early and widespread practical use of photovoltaic energy throughout the United States. (Photovoltaic RD\&D Act 1978) 
Pigure 6-1. RELATIONSHIP EETWEEN THE INTERNATIONAL PHOTOVOLTAIC PLAN AND THE STEPS OF THE PRODUCT DEVELOPMENT PROCESS

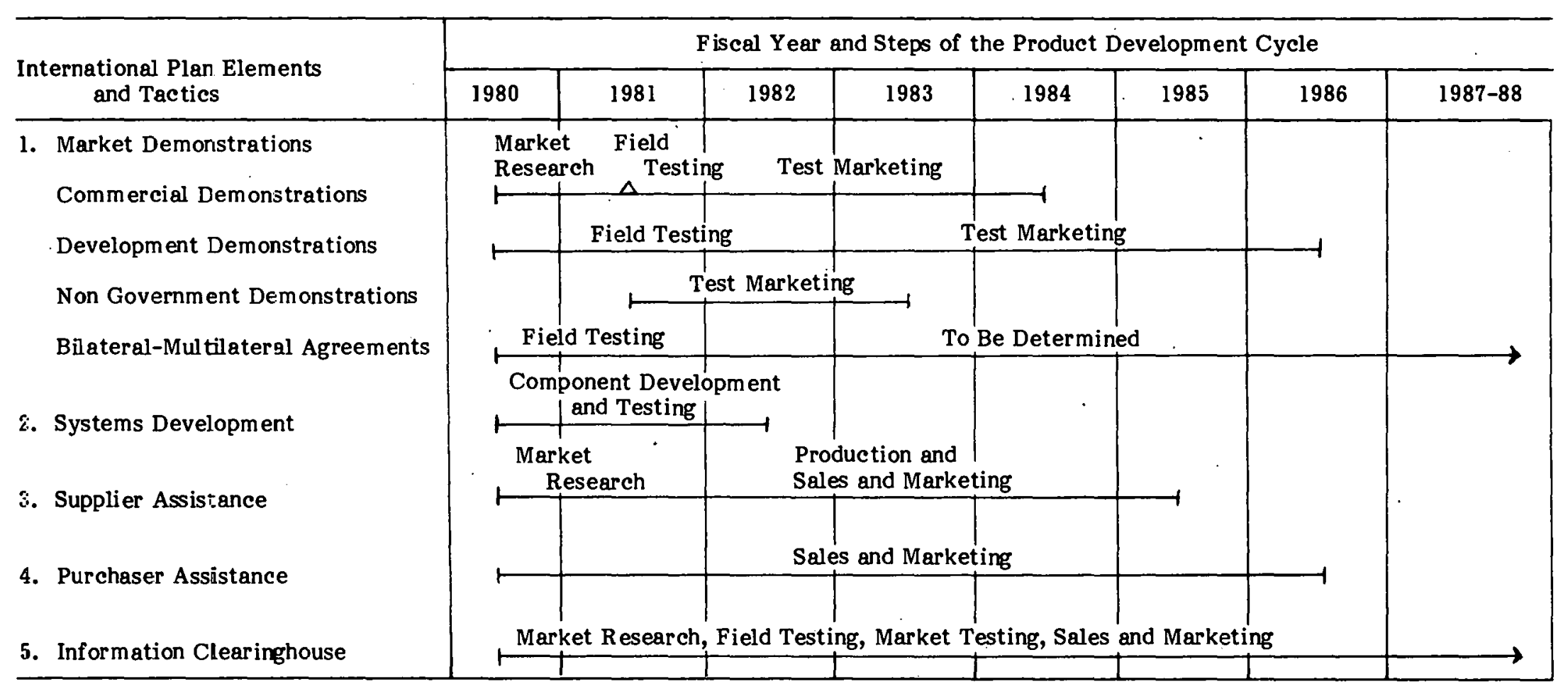


Information dissemination, through the information clearinghouse, the supplier assistance, and the purchaser assistance program elements, plays a predominant role in the plan. The plan is structured with full appreciation of the significance of information generation and distribution in the rapid development of a new technology. Information will be collected and disseminated throughout the duration of the plan. Significant efforts will be devoted to deriving the maximum amount of useful knowledge from the program's demonstration projects.

The Act recognizes the benefit to society of encouraging small business participation in all photovoltaic programs and encourages such actions (\$12). The program elements of the international plan will set aside at least $10 \%$ of the funds to be appropriated to small business. In addition to this policy, the plan takes into account the special problems of small business participation in international markets. Currently, the marketing cost associated with international photovoltaic sales makes it very difficult for small businesses to enter these markets. The promotional assistance tactic of the plan provides direct support to overseas market representatives of small businesses.

Related to small business participation is the Act's emphasis on diverslty und cumpelitiun among photovoltaic system producers. Finding 19 of the Act states, "The Federal Government can stimulate innovation and economic efficiency in the production of photovoltaic energy systems through the development and implementation of policies to promote diversity and maximum competition between firms engaged in research, manufacture, installation, and/or maintenance of these systems" (\$2). The plan is built on the assertion that premature elimination of firms in the business will seriously detract from the normal and healthy evolution of this new industry. The plan requires the participation of at least 10-20 firms in each tactic, and many of the tactics will involve a larger number of firms. The plan also recognizes the fact that competition from other supplier nations forces the U.S. to act swiftly to maintain a competitive position in international markets. In addition, all the tactics of the plan attempt to open or expand photovoltaic markets and help U.S. industry fill these gaps. None of the tactics attempt to further U.S. industry to the detriment of producers in other nations.

The plan also benefits society by encouraging direct contact between suppliers and potential customers. Sec. $2(a)$ of the Act finds that innovation and creativity in the development of photovoltaic products can be fostered by these direct contacts. All of the demonstration tactics in the plan are accomplished by direct supplier end-user interactions with the government acting as a catalyst in the process. The foreign visitor programs and financial assistance to suppliers have been designed to facilitate direct contacts.

The plan serves society by its contribution to the objectives of the Act. The plan will have an impact on production volume and on photovoltaic system costs $(\$ 1(\mathrm{~b})(1)$ and (2)). These impacts can be quantified and were discussed separately in Sec. 6.1. The third objective of the Act is "to stimulate the purchase by private buyers of at least 90 per centum of all solar photovoltalc energy systems produced in the United States during fiscal year 1988" $(\$ \mathrm{l}(\mathrm{b})(3))$. Stimulating U.S. buyers is an indirect result of the plan's impacts on costs and production volumes. The design of the demonstrations in the plan also serves as a means of testing how effectively such demonstrations can be used to stimulate nonsubsidized purchases. The plan focuses on demonstrations and information dissemination, so that nonsubsidized international sales will increase. In this respect, the design of the plan closely parallels the design of the U.S. domestic photovoltaic program. 
Finally, the plan serves the requirements and intent of the Photovoltaic RD\&D Act of 1978 by establishing an aggressive program in the international arena. The policy of the U.S. government to establish aggressive programs over the next decade is stated in $\$ 1(b)$. 
SERI눈 


\section{SECTION 7.0}

\section{REFERENCES}

Aerospace Corporation. March 1977. Mission Analysis of Photovoltaic Solar Energy Conversion: Volume II, Survey of Near-Term Civilian Applications in the United States. Washington, D.C.: Energy Research and Development Agency:

Agency for International Development. June 1978. "Mali Renewable Energy Project, Project Paper." Washington, D.C.: AID.

Baer, Walter; Johnson, Leland; Merrow, Edward. April 1976. Analysis of Federally Funded Demonstration Projects. Santa Monica, CA: Rand Corporation.

BDM Corporation. May 1977, November 1977, February 1978. Photovoltaic Power Systems Market Identification. Draft. Washington, D.C.: U.S. Department of Energy.

Booz, Allen, and Hamilton. September 1978. Assessment of Solar Photovoltaic Industry, Market, and Technologies. Draft report to DOE. Bethesda, MD: Booz-Allen.

Charpie Task Force. February 1978. The Demonstration Project as a Procedure for Accelerating the Application of New Technology. Washington, D.C.: U.S. Department of Energy.

Congressional Record. 1978. U.S. House of Representatives Report No. 95-1285 and U.S. Senate Report No. 95-1262, accompanying S. 3392; Vol. 124.

Congressional Record-Senate. March 1978. A bill to conduct a solar global market survey, submitted to the Senate in 1978.

Costello, Dennis; Posner, David. June 1979. Photovoltaic Procurement Strategies: An Assessment. Draft. Golden, CO: Solar Energy Research Institute.

Costello, Dennis; Posner, David; Schiffel, Dennis; Doane, James; Bishop, Charles. July 1978. Photovoltaic Venture Analysis, Report No. TR-52-040. Golden, CO: Solar Energy Research Institute.

Department of Energy Act of 1978, P.L. 95-238, $\S 2$.

Department of Energy Organization Act of 1977, P.L. 95-91.

Henderson, J. M.; Quandt, R. E. 1971. Microeconomic Theory: A Mathematical Approach. New York, NY: McGraw-Hill; pp. 254-293.

International Development and Food Assistance Act of 1977, P.L. 95-88.

Intertechnology Solar Corporation. January 1978. Photovoltaic Energy Technology Market Analysis. (Draft.) Washington, D.C.: U.S. Department of Energy.

Matlin, R. May 1977. "Design Optimization and Performance Characteristics of a Photovoltaic Microirrigation System for Use in Developing Countries." Cambridge, MA: MIT/66. 
Matlin, R. et al. July 1977. "The Economics of Adopting Solar Photovoltaic Energy Systems in Irrigation." Cambridge, MA: MIT/66.

NASA-Lewis Research Center. March 1979. "Photovoltaic Development and Support Program." Unpublished. Washington, D.C.: The Agency for International Development.

NASA-Lewis Research Center. July 1979. Remote Stand-Alone Applications Implementation Plan. Draft. Cleveland, OH: NASA-Lewis.

National Energy Conservation Policy Act of 1978. Title 5, Federal Energy Initiative; Part 4, Federal Photovoltaic Utilization.

Nuclear Nonproliferation Act of 1978, P.L. 95-242.

Paclfic Northwesl Luburaturies. Apiril 1979. Expont Fotential for Photovoltaic Eys tems: Preliminary Report. Washington, U.C.: U.S. Vepartmeneñt of Energy.

PRC Energy Analysis Company. June 19'/8. Mültiyeár Program Plan, Renewable Energy Alternatives for Developing Countries. Unpublished review draft. McLean, VA: PRC.

PRC Energy Analysis Company. May 1979. Systems Tests and Applications Photovoltaic Program. McLean, VA: DOE, PRC̣.

Rosenbloom, Lewis, et al. February 1979. "Photovoltaic Power System for Rural Areas of Developing Countries." NASA Technical Memorandum 79097. Cleveland, OH: NASA-Lewis Research Center.

Saudi Arabian-United States Joint Commission on Economic Cooperation. October 1977. Project Agreement for Cooperation in the Field of Solar Energy.

Science Applications, Inc. June 1979. Assessment of the Technology Transfer Potential of Federal Photovoltaic Power System Application to Commercial Markets. McLean, VA: Science Applications.

Smith, Douglas V. March 1977. "Photovoltaic Power in Less Developed Countries." Lincoln Laboratory.

Smith, Douglas V. et al. 1978. "Microirrigation with Phótovoltaics." Cambridge, MA: MIT/EL 78-015.

Solar Energy Research, Development, and Demonstration Act of 1974, P.L. 93-473, 2 .

Solar Photovoltaic Energy Research, Development, and Demonstration Act of 1978, P.L. 95-590.

Technical Cooperation Sub-Panel, Solar Energy Domestic Policy Review International Panel. August 1978. Review and Assessment of DOE Technical Cooperation Agreements. Washington, D.C.: U.S. Department of Energy.

U.S. Department of Energy. July 1979. Conservation and Solar Applications Photovoltaics Multiyear Program Plan. Draft. Washington, D.C.: Office of Conservation and Solar Applications, DOE. 
U.S. Department of Energy. January 1979. ETS International Program Plan: Multiyear Program Plan for International Components of Solar, Geothermal, Electric, and Storage Programs. Washington, D.C.: DOE.

U.S. Department of Energy. April 1979. Export Potential for Photovoltaic Systems: Preliminary Report. Washington, D.C.: DOE.

U.S. Department of Energy. June 1979. National Photovoltaic Program Multiyear Program Plan. Draft. Washington, D.C.: Assistant Secretary for Energy Technology, DOE.

William Carey International University. June 1979. "Voluntary Associations in International Development." Pasadena, CA: Unpublished monograph. 


\begin{tabular}{|c|c|}
\hline $\begin{array}{l}\text { Document Control } \\
\text { Page }\end{array}$ & 3. Recipient's Accession No. \\
\hline 4. Title and Subtitle & \multirow{2}{*}{$\begin{array}{l}\text { 5. Publication Date } \\
\text { October } 1979\end{array}$} \\
\hline \multirow[t]{2}{*}{ International Photovoltaic Program Plan, Volumes I \& II } & \\
\hline & 6. \\
\hline $\begin{array}{l}\text { 7. Author(s) Costello, Koontz, Posner, Heiferling, Carpenter, } \\
\text { Forman, Perelman }\end{array}$ & \\
\hline 9. Performing Organization Name and Address & 10. Project/Task/Work Unit No. \\
\hline \multirow{2}{*}{$\begin{array}{ll}\text { Solar Energy Research Institute } \\
\text { 1617 Cole Boulevard } & \text { Jet Propulsion Laboratory } \\
\text { Golden, Colorado } 80401 & 4800 \text { Oak Grove Drive } \\
& \text { Pasadena, Calif. } 91103\end{array}$} & Task No. 5224 \\
\hline & $\begin{array}{l}\text { 11. Contract (C) or Grant (G) No. } \\
\text { (C) }\end{array}$ \\
\hline \multirow[t]{2}{*}{ 12. Sponsoring Organization Name and Address } & $\begin{array}{l}\text { 13. Type of Report \& Period Covered } \\
\text { Technical Report }\end{array}$ \\
\hline & 14. \\
\hline \multicolumn{2}{|l|}{ 15. Sunplementary Nntes } \\
\hline \multicolumn{2}{|c|}{$\begin{array}{l}\text { 16. Abstract (Limit: } 200 \text { words) } \\
\text { The International Photovoltaics Program Plan is in direct response to the Solar } \\
\text { Photovoltaic Energy Research, Development, and Demonstration Act of 1978 (PL 95-590). } \\
\text { As stated in the Act, the primary objective of the plan is to accelerate the } \\
\text { widespread use of photovoltaic systems in international markets. Benefits which } \\
\text { could result from increased international sales by U.S. companies irclude: } \\
\text { stabilization and expansion of the U.S. photovoltaic industry, preparing the } \\
\text { industry for supplying future domestic needs; contribution to the economic and } \\
\text { social advancement of developing countries; reduced world demand for oil; and } \\
\text { improvements in the U.S. balance of trade. The plan outlines programs for } \\
\text { photovoltaic demonstrations, systems developments, supplier assistance, intormation } \\
\text { dissemination/purchaser assistance, and an information clearinghouse. Each program } \\
\text { element includes tactical objectives and summaries of approaches. A program } \\
\text { management office will be established to coordinate and manage the program plan. } \\
\text { Although the U.S. Department of Energy (DOE) had the lead responsibility for } \\
\text { preparing and implementing the plan, numerous federal organizations and agencies } \\
\text { (U:S. Departments of Commerce, Justice, State, Treasury; Agancy for International } \\
\text { Development; ACTION; Export/Import Bank; Federal Trade Commission; Small Business } \\
\text { Administration) were involved In the plan's preparation and Implementatium. }\end{array}$} \\
\hline \multicolumn{2}{|c|}{$\begin{array}{l}\text { 17. Document Analysis } \\
\text { a. Descriptors Photovoltaic Cells ; Market ; Budget ; Financial Data ; International } \\
\text { Aspects ; Legal Aspects ; Legislation ; Environmental Impacts ; Cost Benefit } \\
\text { Analysis ; Demonstration Programs.; Commercialization } \\
\text { b.ldentifiers/Open-Ended Terms Solar Photovoltaic Energy Research, Development, and } \\
\text { Demonstration Act of } 1978 \text {; International Photovoltaics Program Plan }\end{array}$} \\
\hline c. UC Categories & \\
\hline $63,63 a, 63 b, 63 c, 63 d, 63 e$ & \\
\hline $\begin{array}{l}\text { 18. Availability Statement } \\
\text { NTIS, U. S. Dept. of Commerce }\end{array}$ & $\begin{array}{l}\text { 19. No. of Pages } \\
137\end{array}$ \\
\hline $\begin{array}{l}5285 \text { Port Royal Road } \\
\text { Springfield, VA } 22161\end{array}$ & $\begin{array}{l}\text { Price } \\
\$ 7.25\end{array}$ \\
\hline
\end{tabular}

